\author{
AVALIAÇÃO DOS EFEITOS DE DENTIFRÍCIOS \\ CONTENDO CLOREXIDINA SOBRE O DESENVOLVIMENTO \\ DE PLACA DENTÁRIA, GENGIVITE, CÁLCULO E \\ MANCHAMENTO EXTRÍNSECO DO ESMALTE DENTÁRIO EM \\ PACIENTES SOB TRATAMENTO ORTODÔNTICO
}

Dissertação apresentada à Faculdade de Odontologia de Bauru, da Universidade de São Paulo, como parte dos requisitos para obtenção do título de Mestre em Ortodontia e Odontologia em Saúde Coletiva, área de concentração: Odontologia em Saúde Coletiva

(Edição Revisada) 


\section{AVALIAÇÃO DOS EFEITOS DE DENTIFRÍCIOS CONTENDO CLOREXIDINA SOBRE O DESENVOLVIMENTO \\ DE PLACA DENTÁRIA, GENGIVITE, CÁLCULO E MANCHAMENTO EXTRÍNSECO DO ESMALTE DENTÁRIO EM PACIENTES SOB TRATAMENTO ORTODÔNTICO}

Dissertação apresentada à
Faculdade de Odontologia de
Bauru, da Universidade de São
Paulo, como parte dos requisitos
para obtenção do título de Mestre
em Ortodontia e Odontologia em
Saúde Coletiva, área de
concentração: Odontologia em
Saúde Coletiva

(Edição Revisada)

Orientador: Prof. Dr. José Roberto de Magalhães Bastos 


\begin{tabular}{|c|}
\hline Bardal, Priscila Ariede Petinuci \\
B235a \\
clorexidina soãa dos efeitos de dentifrícios contendo \\
gengivite, cálculo e manchamento extrínseco do esmalte \\
dentário em pacientes sob tratamento ortodôntico/ Priscila \\
Ariede Petinuci Bardal - Bauru, 2005. \\
102p. : il. ; 30cm \\
Dissertação (Mestrado) - Faculdade de Odontologia de \\
Bauru. USP \\
Orientador: Prof. Dr. José Roberto de Magalhães \\
Bastos
\end{tabular}

Autorizo, exclusivamente para fins acadêmicos e
científicos, a reprodução total ou parcial desta dissertação, por
processos fotocopiadores elou meios eletrônicos.
Assinatura do autor (a): Priscila Ariede Petinuci Bardal
Data: 22 de fevereiro de 2005 .




\section{PRISCILA ARIEDE PETINUCI BARDAL}

11 de março de 1977

$1995-1998$

$2001-2002$

$2003-2005$

Associações
Nascimento - Agudos - SP

Curso de Odontologia - Escola de Farmácia e Odontologia de Alfenas - Alfenas - MG

Curso de Especialização em Odontologia em Saúde Coletiva - Associação Paulista de Cirurgiões-dentistas - Bauru - SP

Curso de Mestrado em Ortodontia e Odontologia em Saúde Coletiva, opção Odontologia em Saúde Coletiva, pela Faculdade de Odontologia de Bauru, Universidade de São Paulo

CROGO - Conselho Regional de Odontologia de Goiás

SBPqO - Sociedade Brasileira de Pesquisa Odontológica

ABRASCO - Associação Brasileira de Saúde Coletiva 


\section{DEDICATÓRIA}

Dedico essa conquista a DEUS... Minha fonte de vida e de alegria!

Porque Dele, por Ele e para Ele são todas as coisas. A Ele seja a glória. (Bíblia Sagrada - Romanos 12:36)

É muito bom poder contemplar a fidelidade do Senhor em cada detalhe da vida!!!

“ SENHOR.... é tão bom sonhar Teus sonhos;

É tão bom viver Teus planos;

E conhecer a graça de pertencer a Ti: Deus fiel.

É tão bom fechar meus olhos e contemplar com minha fé todas as Tuas palavras e Tuas promessas pra mim...

Deus fiel" 


\section{AGRADECIMENTOS ESPECIAIS}

Ao meu esposo Victor, por compartilhar comigo todos os momentos de vida pessoal e profissional. Obrigada por me apoiar com muito amor, respeito e amizade sincera e incondicional. Agradeço a Deus por tê-lo conhecido e pela felicidade indescritível de construir com você o nosso lar! Eu o amo!!

Aos meus pais Irineu e Djanira, por todo amor que sempre recebi de vocês. Obrigada por nunca medirem esforços em me ajudar. Agradeço toda educação, instrução e apoio oferecidos a mim. Louvo a Deus pela família especial que tenho. Eu os amo muito!

As minhas irmãs Lilian e Joyce, pelas grandes amigas que são. Obrigada por serem tão queridas e por toda força que recebi de vocês em todos os momentos de minha vida. Amo vocês!

A minha avó Palmira, ao meu avô José (in memorian) e a minha tia Alaíde, por participarem de forma tão carinhosa de cada etapa de minha vida. Obrigada pelo cuidado e incentivo a mim dispensados, em todos os momentos. Amo vocês! 


\title{
AGRADECIMENTOS
}

Ao Prof. Dr. José Roberto de Magalhães Bastos, meu orientador, pelos ensinamentos transmitidos e pela oportunidade de aprimorar meus estudos através desse curso de Mestrado. Muito obrigada por sempre me incentivar na busca de meus ideais! Agradeço sua atenção, apoio e amizade. Deus o abençoe!

À Profa. Dra. Marília Afonso Rabelo Buzalaf, pelo modo especial que trata seus alunos. Agradeço a acolhida no Departamento de Bioquímica para a realização de pesquisas no decorrer do Mestrado. Suas palavras de apoio, de ensino e de incentivo nunca serão esquecidas. Obrigada por tudo! Deus a abençoe!

Aos professores do Departamento de Saúde Coletiva, pelos ensinamentos transmitidos e pela amizade.

\begin{abstract}
A minha grande amiga Kelly, pelo companheirismo tão sincero e por todo apoio nas horas mais difíceis. Não vou me esquecer das nossas conversas infindáveis e dos momentos de descontração, mesmo quando as pesquisas pareciam não ter fim.... Obrigada por estar sempre pronta a me ajudar. Sua amizade é muito preciosa. Que Deus a abençoe!
\end{abstract}

Às amigas do curso de mestrado: Lucilene e Fabíola, por serem sempre atenciosas e presentes em todas as horas. Vocês são muito especiais para mim. Obrigada pela amizade! 
À amiga Vanessa, por ser como é! Obrigada pela disponibilidade em ajudar sem medir esforços. Que Deus sempre te oriente no caminho das grandes conquistas! Você é muito especial!

Aos colegas com quem mais convivi no Departamento de Bioquímica da FOB-USP: Esther, Rejane, Juliane, Eduardo, Rodrigo, Juliano, Heloísa e Flávia, agradeço a amizade de vocês!

Aos colegas de mestrado: Ricardo, Roberta, Irene, Beatriz, Fabiano, Hilton, Aline e Haroldo, pela convivência que tivemos nesse tempo de curso.

Aos funcionários do Departamento de Saúde Coletiva da FOB-USP: Silvia, Rosa, Marta e Helena pelo carinho e disponibilidade em me atender sempre que necessário.

Aos funcionários do Departamento de Bioquímica da FOB-USP: Ovídio e Thelma e aos funcionários do Departamento de Ortodontia da FOB-USP: Thiago, Cris e Neide, por toda ajuda.

À Eliz pelo apoio nos dias dos exames clínicos desse estudo. Você foi essencial para que tudo transcorresse da melhor forma possível.

Aos professores do Departamento de Ortodontia da FOB-USP e aos alunos dos cursos de mestrado e especialização em Ortodontia (FOB e APCD), pela atenção.

A Faculdade de Odontologia de Bauru, Universidade de São Paulo, na pessoa de sua Excelentíssima Diretora, Profa. Dra. Maria Fidela de Lima Navarro. 
Aos amigos da Igreja Metodista de Catalão -Goiás, pelas orações, carinho

e atenção oferecidos a mim e ao meu esposo Victor. Deus os abençoe!

A Empresa FGM por tornar possível a realização dessa pesquisa.

A CAPES pelo auxílio financeiro nesse curso de mestrado.

Aos pacientes que aceitaram participar da pesquisa, sem os quais não seria possível a realização desse trabalho.

Eu agradeço! 


\section{SUMÁRIO}

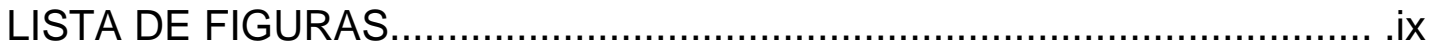

LISTA DE TABELAS

LISTA DE ABREVIATURAS E SÍMBOLOS..............................................ii

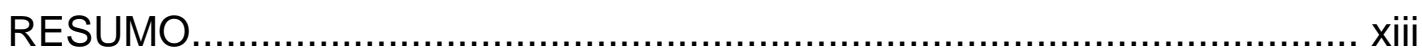

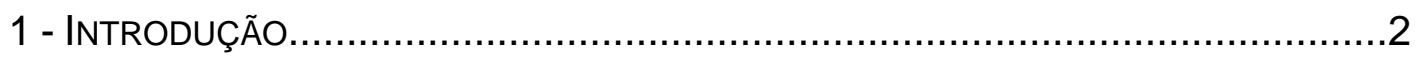

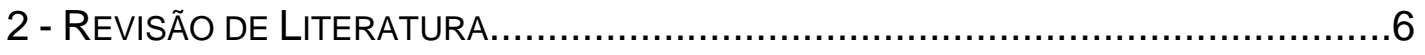

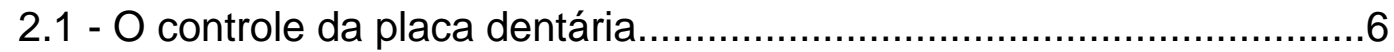

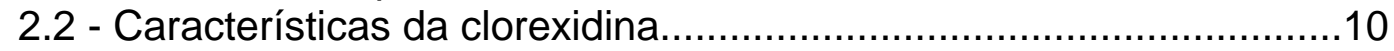

2.2.1 - Mecanismos de ação e veículos de administração.....................12

2.2.2 - Toxicologia e efeitos colaterais............................................16

2.3 -Pacientes em tratamento ortodôntico...............................................18

2.3.1 - Considerações sobre o tratamento ortodôntico..........................18

2.3.2 - O uso da clorexidina em ortodontia.......................................21

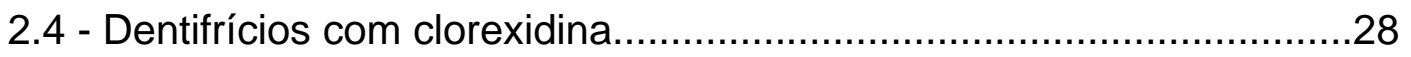

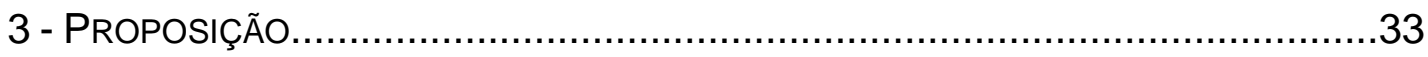

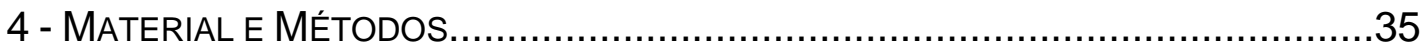

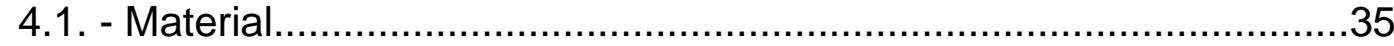

4.1.1 - Seleção dos participantes da pesquisa.....................................35

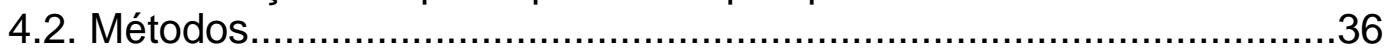

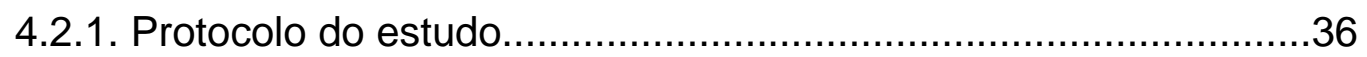

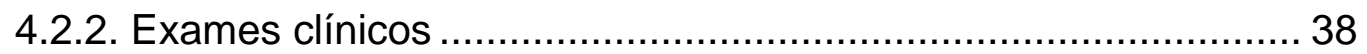

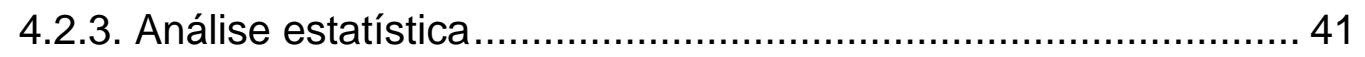

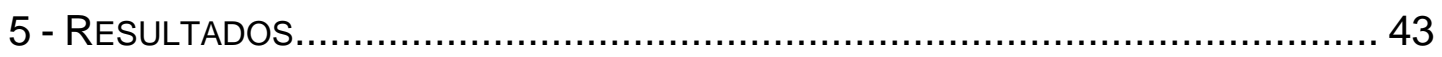

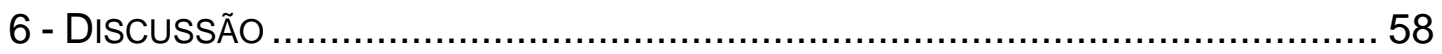

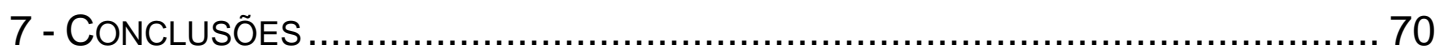

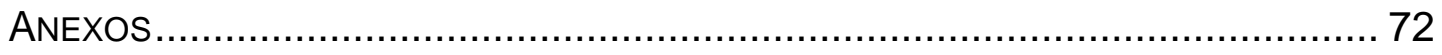

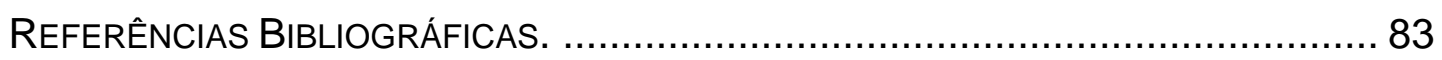

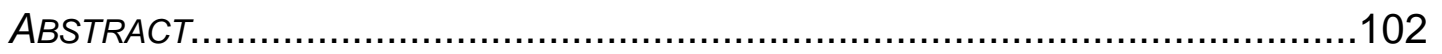




\section{LISTA DE FIGURAS}

FIGURA 1 Médias do índice de manchas nos exames baseline e após 6 e 12 semanas de tratamento com os dentifrícios propostos

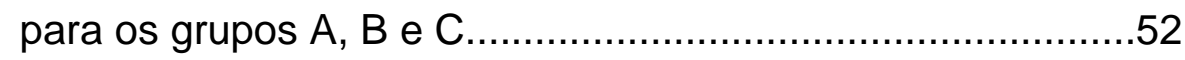

FIGURA 2 Médias do índice de tártaro nos exames baseline e após 6 e 12 semanas de tratamento com os dentifrícios propostos para os grupos A, B e C .53

FIGURA 3 Médias do índice gengival nos exames baseline e após 6 e 12 semanas de tratamento com os dentifrícios propostos para os

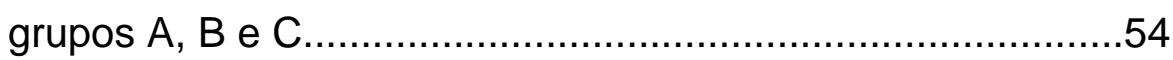

FIGURA 4 Médias do índice de sangramento gengival nos exames baseline e após 6 e 12 semanas de tratamento com os dentifrícios propostos para os grupos A, B e C...... .55

FIGURA 5 Médias do índice de placa dentária nos exames baseline e após 6 e 12 semanas de tratamento com os dentifrícios propostos para os grupos A, B e C 


\section{LISTA DE TABELAS}

TABELA 1 Médias (dp) do Índice de Manchas (IM) dos grupos A, B e C, nos tempos: baseline, 6 e 12 semanas de utilização dos dentifrícios. 44

TABELA 2 Análise clínica da distribuição do IM de acordo com as superfícies vestibulares e linguais, nos grupos A, B e C, considerando os exames baseline e após 6 e 12 semanas de utilização dos dentifrícios 44

TABELA 3 Médias (dp) do Índice de Tártaro (IT) dos grupos A, B e C, nos tempos: baseline, 6 e 12 semanas de utilização dos dentifrícios 45

TABELA 4 Médias (dp) do Índice Gengival (IG) dos grupos A, B e C, nos tempos: baseline, 6 e 12 semanas de utilização dos dentifrícios 46

TABELA 5 Média (dp) dos scores 0, 1, 2 e 3 do Índice Gengival para os grupos A, B e C, conforme cada exame realizado. 46

TABELA 6 Médias (dp) do Índice de Sangramento (IS) dos grupos A, B e C, nos tempos: baseline, 6 e 12 semanas de utilização dos dentifrícios 48

TABELA 7 Evolução clínica da média do número de pontos sangrantes (dp), de acordo com os grupos A, B e C, considerando o exame realizado e a região do dente (superfícies livres e proximais). 48

TABELA 8 Médias (dp) do Índice de Placa (IP) dos grupos A, B e C, nos tempos: baseline, 6 e 12 semanas de utilização dos dentifrícios 49

TABELA 9 Evolução da média (dp) do número de pontos com presença de placa $(\mathrm{N})$ dos grupos $\mathrm{A}, \mathrm{B}$ e $\mathrm{C}$, de acordo com o exame realizado e a região do dente (cervical, central e oclusal. .50 
TABELA 10 Porcentagens de redução/aumento das médias de cada índice do grupo A, considerando o baseline em relação ao exame após 6 semanas e o exame de 6 semanas em relação ao de 12 semanas............................................................. 50

TABELA 11 Porcentagens de redução/aumento das médias de cada índice do grupo $\mathrm{B}$, considerando o baseline em relação ao exame após 6 semanas e o exame de 6 semanas em relação ao de 12 semanas. .51

TABELA 12 Porcentagens de redução/aumento das médias de cada índice do grupo C, considerando o baseline em relação ao exame após 6 semanas e o exame de 6 semanas em relação ao de 12 semanas. 51 


\section{LISTA DE ABREVIATURAS}

APCD - Associação Paulista de Cirurgiões-Dentistas

F - flúor

FI - Flúor iônico

FT - flúor total

FS - flúor solúvel

FOB - Faculdade de Odontologia de Bauru

$\mathrm{mL}-$ Mililitro

mg - miligrama

$\mathrm{NaF}$ - fluoreto de sódio

OMS - Organização Mundial da Saúde

p - nível de significância

ppm - parte por milhão

USP - Universidade de São Paulo 


\section{RESUMO}

Foram analisados os efeitos de formulações de dentifrícios contendo clorexidina (adicionadas ou não de flúor) na redução de placa dentária, gengivite e sangramento gengival em pacientes sob tratamento ortodôntico. Analisou-se ainda a ocorrência de um efeito colateral da clorexidina - o manchamento extrínseco do esmalte dentário - e a prevalência de cálculo dentário. Um total de 83 pacientes (13 a 32 anos de idade) participaram desse estudo clínico randomizado. Os participantes utilizaram por 3 meses os respectivos dentifrícios de acordo com seu grupo: grupo A - Sorriso Fresh Red Mint ${ }^{\circledR}, 1100$ ppm F (NaF) - Kolynos do Brasil Ltda; grupo B - dentifrício experimental com 1100 ppm $\mathrm{F}(\mathrm{NaF})$ e clorexidina 0,95\% (digluconato de clorexidina) - $F G M \otimes$, Joinville e grupo $C$ - dentifrício experimental com clorexidina $0,95 \%$ (digluconato de clorexidina) - FGM ${ }^{\circledR}$, Joinville. Foram realizados exames baseline, após 6 e 12 semanas para verificação dos índices de placa, gengival e sangramento. O manchamento extrínseco do esmalte e a presença de cálculo dentário também foram observados. Os dentifrícios com clorexidina (adicionados ou não de flúor) foram estatisticamente mais eficazes que o dentifrício controle no que se refere às reduções dos Índices Gengival e de Sangramento. O benefício máximo foi verificado nos grupos $B$ e C, nos exames após 6 semanas de utilização dos dentifrícios, sendo mantido até o final do experimento. Em relação ao Índice de Placa, os três grupos apresentaram reduções estatisticamente significantes no exame de 6 semanas, sendo que os resultados dos grupos $\mathrm{B}$ e $\mathrm{C}$ foram melhores comparados ao grupo $\mathrm{A}$. Foi observado um aumento estatisticamente significante do índice de manchas e não houve aumento dos valores referentes ao cálculo dentário nos grupos B e C. A utilização do $\mathrm{NaF}$ juntamente com a clorexidina não provocou a inativação da mesma. $\mathrm{O}$ uso terapêutico de dentifrícios com clorexidina (adicionados ou não de flúor) pode ser visto como a uma forma simples e eficaz de administração do agente químico aos pacientes com dificuldades na manutenção de uma higiene bucal satisfatória, como os pacientes ortodônticos. 
INTRODUCÃO 


\section{INTRODUÇÃo}

A Odontologia Preventiva tem se destacado na área da saúde. Os cuidados com a saúde bucal têm ido além de aspectos estéticos. No novo paradigma de saúde se desperta uma maior consciência sobre a necessidade de se manter uma saúde bucal satisfatória que, por sua vez, é refletida na saúde geral.

Os profissionais da saúde têm a responsabilidade de atuar na prevenção de doenças, minimizando riscos e promovendo condições favoráveis para que se torne possível alcançar e manter a saúde bucal. Por outro lado, os pacientes também precisam ser despertados sobre o seu papel nos cuidados com a saúde.

Um dos principais e mais comuns desafios na prevenção em saúde bucal é o controle de placa dentária e, conseqüentemente, o controle da cárie dentária e da inflamação gengival (CARVALHO et al. ${ }^{40}$, 1991; SEKINO et al. ${ }^{149}$, 2003; SREENIVASAN et al. ${ }^{158}$, 2003). Para tanto, os métodos mecânicos através do uso de escova e fio dental são tidos como eficazes, mas não suficientes, em certos casos (TORRES $\left.{ }^{162}, 2000\right)$.

Situações locais e/ou sistêmicas podem ocasionar dificuldades para a realização de uma higiene bucal eficiente. Incluem-se nestas indivíduos idosos; com limitações físicas ou mentais; com dentes mal posicionados; com aparelhos ortodônticos fixos, entre outros $\left(\mathrm{CIANCIO}^{46}, 1988\right.$; BAKER ${ }^{13}$, 1993). Dessa forma, a prescrição de substâncias químicas pode ser indicada como coadjuvante da higienização $\left(C U R Y^{47}, 1999\right)$.

Os pacientes submetidos ao tratamento ortodôntico fixo apresentam retentores adicionais de placa dentária na cavidade bucal. Os bráquetes, bandas e demais acessórios próprios do tratamento, podem levar à desmineralizações do esmalte, causando mancha branca, cárie dentária e gengivite. (FELIU ${ }^{62}$, 1982; UETANABARO, MARTINS, ANDRADE ${ }^{163}$, 1984; HEINTZE ${ }^{86}$, 1996; TAMBURUS, BAGATIN, NETTO ${ }^{161}$, 1998; GLANS et al. ${ }^{76}$, 2003; DERKS et al. ${ }^{53}$, 2004). Isso faz com que esse grupo de pacientes tenha que se empenhar ainda mais na realização da higiene bucal, pois é 
particularmente difícil manter uma higiene bucal aceitável quando bandas, fios e ligaduras estão presentes (LUNDSTRON; HAMP ${ }^{111}, 1980$ ).

Pode-se observar nos pacientes que fazem uso de aparelhos ortodônticos fixos que o controle efetivo da placa dentária através de métodos mecânicos sofre algumas limitações. Dessa forma, o importante papel dos agentes químicos, na melhora da saúde bucal, deve ser considerado observando cada caso (HEINTZE ${ }^{86}$, 1996; STEFANI; LIMA ${ }^{160}$, 1996; GARIB et al. $\left.{ }^{67}, 1997\right)$.

Levando em conta as propriedades das substâncias disponíveis e os resultados clinicamente comprovados, a clorexidina é aclamada como o "padrão ouro" em comparação aos demais produtos desenvolvidos para atuarem sobre a formação de placa e desenvolvimento de gengivite (VINHOLIS et al. ${ }^{168}$, 1996; JONES $^{97}$, 1997). Entretanto, alguns efeitos colaterais decorrentes de seu uso podem ser ocasionados e, o mais comum desses é o manchamento extrínseco do esmalte dentário (DOLLES; ERIKSEN; GJERMO ${ }^{55}$, 1979; GREENSTEIN; BERMANT; JAFFIN ${ }^{79}, 1986$; SANTOS $^{139}$, 2003).

Sabe-se que a forma mais comum de utilização da clorexidina é através de bochechos com soluções a 0,12\% e 0,2\% (IACONO, et al. ${ }^{90}$, 1998; PUPPIN FILHO; FEITOSA; GANHOTO ${ }^{129}$, 2001), respeitando-se a forma de administração para que não seja inativada pelos componentes residuais dos dentifrícios na cavidade bucal $\left(\right.$ CIANCIO $^{45}, 1998$; SANTOS ${ }^{139}$, 2003). Além das soluções, a clorexidina pode ser também administrada em outros veículos como os géis, vernizes, dentifrícios, chips e sprays (FEIST; MICHELI; SARIAN ${ }^{61}$, 1989; TORRES ${ }^{162}$, 2000; SREENIVASAN; GAFFAR ${ }^{159}$, 2002)

Um número expressivo de pesquisas científicas demonstram a ação da clorexidina sobre a placa dentária, gengivite e cárie dentária (BLOOM; BROW $^{29}$, 1964; SAKAMAKI; BAHN ${ }^{138}$, 1968; GRECO et al. ${ }^{78}, 1974$ SADOWSKY; BEGOLE ${ }^{137}$, 1981, UETANABARO; MARTINS; ANDRADE ${ }^{163}$, 1984; CARVALHO et al. $^{40}, 1991$; AXELSSON ${ }^{8}, 1993$; SANZ et al. ${ }^{140}$, 1994; van RIJKOM; TRUIN; van't HOF ${ }^{166}$, 1996; TAMBURUS; BAGATIN; 
NETTO ${ }^{161}, 1998$; SREENIVASAN et al. ${ }^{158}, 2003$; SEKINO et al. ${ }^{149}$, 2003). No entanto, sua utilização tendo o dentifrício como veículo de administração ainda é controversa, pois a natureza catiônica da clorexidina faz com que ela interaja com alguns detergentes e certos componentes aniônicos contidos nos dentifrícios. A clorexidina também pode ser inativada na presença de fosfatos, sulfatos além de sofrer uma inibição competitiva verificada na presença de cálcio (BARKVOLL; ROLLA; SVENDSEN ${ }^{16}, 1989$; VAN GRUNSVEN; CARDOSO ${ }^{165}$, 1995).

Considerando o fato de que a escovação com dentifrícios é o hábito mais comum de higiene bucal (SHEIHAM ${ }^{151}$, 1970; FRANDSEN ${ }^{65}$, 1986; OWENS et al. $\left.{ }^{126}, 1997\right)$, a adição da clorexidina aos dentifrícios poderia ser vista como uma forma prática de utilização do agente químico, tendo em vista a melhora da saúde bucal (MURRAY; RUGG-GUNN ${ }^{120}, 1982$ ).

Poucos estudos têm sido feitos para verificação dos efeitos de dentifrícios com clorexidina. Entretanto, DOLLES; GJERMO ${ }^{56}, 1980$; YATES et al. $^{169}$, 1993; GUGUSHE; WET; ROJAS-SILVA ${ }^{83}$, 1994, obtiveram resultados animadores quando da utilização desses dentifrícios.

Essa pesquisa foi delineada tendo em vista a possibilidade de uso da clorexidina em dentifrícios como coadjuvante na higiene bucal e, o fato de pacientes ortodônticos possuírem fatores indicativos de maior risco à cárie e gengivite. Pretendeu-se então, analisar os efeitos de dentifrícios experimentais contendo clorexidina (adicionada ou não de flúor) na redução de placa dentária, gengivite e sangramento gengival em pacientes sob tratamento ortodôntico, além de se avaliar a presença de manchamento extrínseco do esmalte dentário e a prevalência de cálculo dentário nesses pacientes. 
REVISÃO DE LITERATURA 


\section{REVISÃo dE LITERATURA}

\subsection{O controle da placa dentária}

O enfoque na prevenção de doenças e promoção de saúde tem norteado as ações nas diversas especialidades odontológicas. No entanto, um dos maiores desafios para o cirurgião-dentista ainda é o controle da placa dentária, fator determinante para a obtenção de resultados satisfatórios durante e após os tratamentos, considerando tanto a cárie dentária como a doença periodontal (BLOOM; BROW ${ }^{28}$, 1964; SAKAMAKI; BAHN $^{138}$, 1968; GRECO et al. ${ }^{78}$, 1974; SADOWSKY et al. ${ }^{137}, 1981$, UETANABARO; MARTINS; ANDRADE ${ }^{163}, 1984$; CARVALHO et al $.^{40}, 1991$; AXELSSON $^{8}$, 1993; SANZ et al. ${ }^{140}$, 1994; van RIJKOM; TRUIN, van't HOF ${ }^{166}$, 1996; SREENIVASAN et al. ${ }^{158}$, 2003; SEKINO et al. ${ }^{149}, 2003$; TAMBURUS; BAGATIN; NETTO ${ }^{161}, 1998$ ).

Os métodos mecânicos para remoção de placa dentária requerem tempo, motivação e destreza manual (DePAOLA et al. ${ }^{51}, 1989$ ). Mesmo os pacientes que são adequadamente treinados e instruídos para manterem sua higiene satisfatória, na ausência de um constante reforço sobre os aspectos de educação em saúde, os níveis de cooperação diminuem de forma significante (AXELSON; LINDHE ${ }^{9}$, 1987). Levando-se em conta esses fatores, não se pode negligenciar que, no ambiente doméstico, possam existir certas limitações para que a correta higiene bucal possa ser realizada (SANTOS ${ }^{139}$, 2003).

Pacientes idosos, indivíduos com limitações físicas ou mentais, com dentes mal posicionados e/ou com aparelhos ortodônticos fixos, podem, muitas vezes, apresentar dificuldades quanto à escovação dentária e ao uso de fio dental $\left(\mathrm{CIANCIO}^{45}, 1988 ; \mathrm{BAKER}^{13}, 1993\right)$. Além do que, certas condições locais e/ou sistêmicas determinam um comprometimento momentâneo ou definitivo da habilidade do paciente na realização do controle mecânico caseiro da placa supragengival (NEWMAN; KORNMAN ${ }^{123}$, 1997). Mesmo assim, não é indicado o uso de 
antimicrobianos de forma indiscriminada e sem acompanhamento (BOWEN ${ }^{33}, 1999$ ).

Métodos mecânicos como escova/dentifrício e utilização de fio dental, quando aplicados de forma eficiente, conseguem promover um correto controle de placa (OWENS et al. ${ }^{126}, 1997$; TORRES ${ }^{162}, 2000$ ). Entretanto, CURY $^{47}, 1999$, enfatiza a necessidade de se prescrever substâncias químicas anti-placa para pacientes que tenham dificuldades de manter um correto controle de placa dentária. Dependendo das características do paciente, alguns autores consideram pertinente a realização do controle químico da placa como coadjuvante ao controle mecânico, podendo até substitui-lo por curtos períodos de tempo quando necessário (CARVALHO et al. ${ }^{40}, 1991 ;$ CURY $^{47}, 1999$; TORRES ${ }^{162}, 2000$ ).

O desenvolvimento de produtos para o controle químico da placa dentária supragengival é uma alternativa para que se consiga a sua adequada eliminação (SANZ et al. ${ }^{140}$, 1994; ZAMPATTI; ROQUES; MICHEL ${ }^{173}, 1994$; OWENS et al. $\left.{ }^{126}, 1997\right)$.

Os atributos necessários para que um agente químico possa desempenhar sua eficácia no controle da placa supragengival foram postulados por $\mathrm{LOESCHE}^{109}$ em 1976 e seguem constituindo os pilares básicos na análise crítica do emprego clínico destes produtos. $\mathrm{O}$ autor afirma que o agente químico deve ser eficaz contra os microrganismos responsáveis pela inflamação gengival e deve possuir substantividade, isto é, a capacidade de retenção intrabucal, para que tenha tempo de contato suficiente para agir sobre a microbiota existente, e para que mantenha a inibição de formação da placa por um período mais prolongado. Além disso, o produto necessita ser estável à temperatura ambiente por tempo considerável e ser seguro para utilização em seres humanos.

Outras características também devem ser observadas para que um agente químico seja considerado eficaz, tais como: ausência de toxicidade, não ser alergênico, ter comprovação clínica de reduções significantes de placa e gengivite, ser seletivo e ter especificidade para agir na microbiota 
patogência, apresentar sabor agradável, ter custo acessível e ser de fácil utilização (VAN DER OUDERAA ${ }^{164}, 1991$ ).

Desde o início da década de 70 foram desenvolvidas diversas substâncias para controle químico da placa supragengival, incluindo-se aqui o uso da clorexidina (GJERMO et al. ${ }^{73}, 1970$ ).

Uma das primeiras aplicações da clorexidina no controle de placa dentária foi em 1970, quando LÖE e SCHIOTT ${ }^{107}$ relataram que o uso de 10 $\mathrm{mL}$ de solução de digluconato de clorexidina a 0,2\%, duas vezes ao dia, por um minuto, prevenia o acúmulo de placa e subseqüente gengivite. A partir de então, esse composto catiônico do grupo dos bisbiguanídeos vem sendo aclamado como o agente mais efetivo para o controle químico da placa bacteriana por diferentes décadas (LÖE; SCHIOTT ${ }^{107}$, 1970; LÖE ${ }^{105}$, 1973; SCHIOTT ${ }^{145}$, 1973; GJERMO ${ }^{72}$, 1974; SANZ et al. ${ }^{140}$, 1994; JONES $^{97}$, 1997; PUPPIN FILHO; FEITOSA; GANHOTO ${ }^{129}$, 2001).

Ao descreverem o desempenho da clorexidina no controle da placa bacteriana, FEIST; MICHELI; SARIAN ${ }^{61}$, 1989, realizaram uma revisão de literatura sobre os vários métodos de aplicação da substância, bem como variações de concentração, duração do tratamento, efeitos colaterais, retenção, absorção e atuação sobre a microbiota. Segundo os trabalhos analisados, a clorexidina foi considerada a substância química mais eficiente no controle químico da placa bacteriana, seja na forma de bochechos $(0,12 \%$ a $0,2 \%)$ ou na forma de aplicação tópica (0,2\% a 2,0\%).

Os autores DEL BEL CURY; REBELO; CURY ${ }^{48}$, 1994, realizaram uma pesquisa para estudar se um bochecho contendo clorexidina associada ao flúor seria promissor em termos de redução de placa e incorporação de flúor no esmalte dentário humano. Avaliou-se desta forma, uma formulação experimental contendo $\mathrm{NaF}$ a $0,05 \%$ e clorexidina a 0,12\% em comparação com o placebo. Os voluntários fizeram uso de dispositivo intra-oral palatino contendo 4 blocos de esmalte dentário humano. A diferença de redução de formação de placa dentária da ordem de 74\%, devido ao tratamento clorexidina/flúor, foi significativa, mesmo em condições de alto desafio induzido pelo bochecho com sacarose a $20 \%$. No grupo experimental 
também se observou maior incorporação de flúor na superfície do esmalte dentário. Não houve interferência no efeito do flúor, mesmo com a associação com clorexidina. Os autores sugeriram que esse bochecho seria particularmente indicado para pacientes com alto risco de desenvolvimento de cárie, principalmente durante as fases ativas do tratamento. JENKINS; ADDY; NEWCOMBE ${ }^{94}$ 1993, também afirmaram que a associação de clorexidina e flúor em soluções para bochechos foi promissora, após a obtenção de resultados estatisticamente significantes dos índices de placa e gengival após 6 semanas de uso, mesmo com o aumento do manchamento extrínseco de esmalte. No entanto, Freitas et al. ${ }^{66}, 2003$, verificaram in vitro que a associação da clorexidina ao fluoreto de sódio promoveu uma diminuição de sua substantividade. No entanto, nesse estudo a substantividade foi medida somente através da dessorção da clorexidina a partir dos fragmentos de esmalte bovino previamente imersos nas soluções teste e, posteriormente colocados em água destilada.

Com a finalidade de verificar a eficiência do gel de clorexidina a $1 \%$ na redução da placa e do sangramento gengival à sondagem, VILLALPANDO; TOLEDO ${ }^{167}$, 1997, acompanharam 12 pacientes portadores de periodontite inicial, moderada ou avançada, que foram divididos em três grupos de 4 pessoas: No Grupo I, o gel foi aplicado apenas uma vez, imediatamente após a raspagem e alisamento dentário; no Grupo II, a clorexidina foi aplicada topicamente a cada três dias e os pacientes do Grupo III usaram o gel durante a escovação dentária, três vezes ao dia. Os resultados mostram que o uso continuado e constante da clorexidina (Grupo III) foi bem mais efetivo tanto na redução do Índice de Placa como do Índice Gengival e que, quando houve redução da placa dentária, também ocorreu redução de sangramento gengival à sondagem. Os autores indicaram a utilização do gel de clorexidina a 1\% como substituto do dentifrício, após a raspagem do dente e alisamento radicular ou em pós-operatórios cirúrgicos por curtos períodos de tempo.

Estudos de curta duração indicaram que a clorexidina reduz placa dentária e gengivite em proporções de aproximadamente 60\%. Outras 
pesquisas, de longa duração, demonstraram redução de $55 \%$ de placa e $45 \%$ de gengivite (SINNES et al. $\left.{ }^{153}, 1997\right)$.

Existem razões bem fundamentadas para a utilização de substâncias químicas no controle da placa dentária atuando tanto na prevenção como no tratamento de doenças periodontais $\left(\right.$ BOUWSMA $\left.^{30}, 1996\right)$, como na prevenção da cárie (van RIJKOM, TRUIN, van't HOF ${ }^{166}$, 1996).

Segundo CURY $^{47}, 1999$, a primeira destas razões, diz respeito ao fato de que, tanto a doença cárie, quanto as doenças dos tecidos moles, são de origem bacteriana e, deste modo, substâncias antibacterianas poderiam ser usadas para combatê-las. Uma segunda razão é aquela decorrente da dificuldade de se conseguir que os indivíduos mantenham um adequado controle mecânico da placa, e então substâncias poderiam tentar compensar a dificuldade/desmotivação para uma boa limpeza dos dentes. Entretanto, vale acrescentar que a realização do controle químico da placa deve ser feita com racionalidade, levando em conta que os antimicrobianos possuem a posição de coadjuvantes na higienização bucal.

\subsection{Características da clorexidina}

Ao final dos anos 40, cientistas desenvolvendo agentes antimalária, formularam um grupo de compostos denominados polibiguanidas, o qual demonstrou um amplo espectro antimicrobiano. Uma das drogas criadas nesta época foi a clorexidina que passou a ser usada como um antisséptico geral para o tratamento de diferentes infecções (LÖE ${ }^{105}, 1973$; GREENSTEIN; BERMAN; JAFFIN ${ }^{79}$, 1986; PUPPIN FILHO; FEITOSA; GANHOTO $^{129}$, 2001).

Posteriormente, a clorexidina foi introduzida no mercado na década de 60 pela Imperial Chemical Industries - Inglaterra, como um desisfetante geral com largo espectro antibacteriano para bactérias tanto gram-positivas como para gram-negativas (BASTOS; LOPES; RAMIRES ${ }^{24}, 2001$ ). Uma das primeiras aplicações da clorexidina em Odontologia para o controle de placa dentária foi realizada em 1970 por LOE E SCHIOTT ${ }^{107}$. 
Essa substância pode ser definida como uma bisguanidina catiônica, disponível nas formas de sais de gluconato, digluconato ou acetato (GJERMO $^{72}$, 1974; HERBERT, et al. ${ }^{89}$, 2003). O digluconato de clorexidina é a forma mais indicada, pois tem maior solubilidade em água e, em $\mathrm{pH}$ fisiológico, dissocia-se, liberando o componente catiônico. A clorexidina é o componente ativo mais efetivo contido nos enxaguatórios bucais, usados para prevenir a placa dentária e a gengivite (SINNES et al. $\left.{ }^{153}, 1997\right)$.

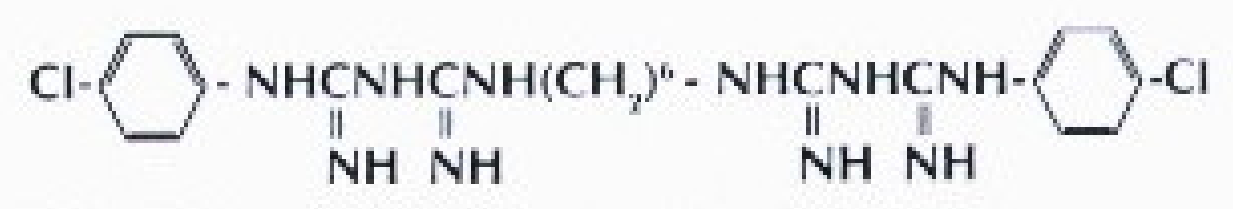

Fórmula Estrutural da Clorexidina

Atualmente é usada como adjunto ao agente mecânico, em casos de ausência de coordenação motora, presença de alterações sistêmicas que modificam o curso da doença periodontal, doenças periodontais agudas, casos de alto risco a cárie, para pacientes com fatores retentivos de placa, após cirurgias da cavidade bucal, incapacidade física ou mental, fluxo salivar reduzido (medicamentos, radioterapia e síndromes), cárie rampante e cárie radicular, reconstrução protética extensa, paciente com implantes e também antes do atendimento odontológico para diminuir a dispersão de microorganismo durante os procedimentos que formam aerossóis (ARSENIAN; PEREZ; NUNES ${ }^{7}, \quad 1992 ;$ JOYSTON-BECHAL ${ }^{98}, \quad 1992$; BASTOS; HENRIQUES; OLYMPIO ${ }^{26}$, 2001; PAVARINA et al. ${ }^{127}$, 2003; VAN GRUNSVEN; CARDOSO ${ }^{165}, 1995$; CARVALHO et al. ${ }^{40}, 1991$; HERBERT, et al. $\left.{ }^{89}, 2003\right)$.

Levando-se em conta a importância do tempo e da freqüência do bochecho, a inibição da placa dentária pela clorexidina foi demonstrada ser dose-dependente (CANCRO et al. $^{38}$, 1974). Resultados similares foram encontrados com a administração de soluções de clorexidina a 0,12\%, em 
volumes de $15 \mathrm{~mL}$ (18 $\mathrm{mg}$ ), duas vezes ao dia, quando comparados aqueles com soluções de clorexidina a $0,2 \%$ em volumes de $10 \mathrm{~mL}(20 \mathrm{mg})$ durante um minuto, duas vezes ao dia (SEGRETO et al. ${ }^{148}, 1986$; IACONO et al. ${ }^{90}$, 1998). Os produtos europeus costumam ser comercializados em soluções a $0,2 \%$, enquanto que nos Estados Unidos as soluções são comumente apresentadas a 0,12\% (JENKINS; ADDY; NEWCOMBE ${ }^{92}$, 1994).

As propriedades antibacterianas da clorexidina fazem com que esse agente seja considerado o "padrão ouro" em comparação às demais substâncias desenvolvidas para agir sobre a formação de placa e desenvolvimento de gengivite (GREENSTEIN; BERMANT; JAFFIN ${ }^{79}$, 1986; ELWORTHY et al. ${ }^{59}, 1996$; VINHOLIS et al. ${ }^{168}, 1996$ JONES $^{97}, 1997$; OWENS et al. ${ }^{126}$, 1997; BOWEN $\left.{ }^{33}, 1999\right)$.

O controle de placa com o uso da clorexidina tem sido recomendado principalmente por períodos restritos de tempo. Entretanto, em certas circunstâncias, o uso prolongado pode ser viável (LUCAS; LUCAS ${ }^{110}, 1997$; BASTOS; LOPES; RAMIRES $\left.{ }^{24}, 2001\right)$. CHADWICK $^{43}, 1994$ afirma que a clorexidina deve ser vista como uma substância complementar ao controle mecânico sem se excluir os reforços e instruções de higiene bucal.

Estudos evidenciaram a eficácia da clorexidina na redução significante de placa e gengivite quando usadas duas vezes ao dia como um suplemento da escovação dentária, em forma de bochechos (LÖE et al. ${ }^{106}$, 1976; LANG et al. ${ }^{102}$, 1982; GROSSMAN; REITER; STURZENBERGER ${ }^{81}$, 1986). Reduções expressivas desses índices têm sido superiores àquelas promovidas por outros agentes químicos como o Listerine e Triclosan (LAMSTER et al. ${ }^{100}$, 1983; GORDON; LAMSTER; SEIGER ${ }^{77}, 1985$; SCHEIE ${ }^{143}, 1989$; CIANCIO ${ }^{45}, 1995$; IACONO et al. $\left.{ }^{90}, 1998\right)$.

\subsubsection{Mecanismos de ação e veículos de administração}

A clorexidina apresenta tanto atividade antibacteriana quanto efeito antiplaca. O espectro de ação dessa substância é amplo (van RIJKOM; TRUIN; van't HOF ${ }^{166}$, 1996; SREENIVASAN et al. $\left.{ }^{158}, 2003\right)$, abrangendo 
bactérias Gram-positivas e Gram-negativas, leveduras, dermatófilos e alguns vírus lipofílicos (JONES $\left.{ }^{97}, 1997\right)$. Microrganismos Gram positivos são mais susceptíveis à clorexidina do que os Gram negativos. Deste modo, os estreptococos são mais atingidos que que os estafilococos (HENNESSEY ${ }^{88}$, 1973). O efeito da clorexidina também se dá sobre a Candida albicans. Aplicações de clorexidina em solução a 0,2\% reduzem de 80 a $90 \%$ a colonização de microrganismos e, cessado o uso, a colonização retorna ao seu nível inicial em 48 horas (SCHIOT et al. ${ }^{144}, 1970$; AXELSSON ${ }^{8}, 1993$ ).

Quando administrada, a molécula catiônica da clorexidina é atraída para a superfície celular bacteriana e adsorve os componentes fosfatados. Altera-se então a integridade da membrana e a clorexidina se une aos fosfolipídeos na membrana interna, promovendo um aumento da permeabilidade celular e conseqüente extravasamento de compostos intracelulares de baixo peso molecular, tais como íons potássio. Nesse estágio, o efeito é considerado bacteriostático e reversível. Em concentrações mais altas, ocorre a coagulação e precipitação do citoplasma, pela formação de compostos fosfatados, chegando-se ao estágio bactericida e irreversível (GJERMO ${ }^{72}$, 1974; GREENSTEIN; BERMANT; JAFFIN ${ }^{79}$, 1986; JONES ${ }^{97}$, 1997; IACONO et al. $\left.{ }^{90}, 1998\right)$.

A ação da clorexidina é tópica e seu efeito antiplaca é creditado à sua habilidade de adsorção a substratos aniônicos da cavidade bucal, tais como: hidroxiapatita, película adquirida, glicoproteínas salivares e membranas mucosas. Este mecanismo de ação acaba por conferir a esta substância uma grande substantividade na cavidade bucal (GJERMO ${ }^{72}$, 1974; ADDY ${ }^{1}$, 1989; VINHOLIS et al. ${ }^{168}$, 1996; ELWORTHY et al. ${ }^{59}, 1996$; JONES $^{97}, 1997$; SANTOS ${ }^{139}$, 2003).

A adsorção da clorexidina às várias estruturas bucais forma os "reservatórios de clorexidina", resultando em um efeito duradouro. As mucosas adsorvem mais clorexidina, talvez pelo fato de conter glicoproteínas sulfatadas com potencial aniônico. Deste modo, a renovação normal das secreções acaba por se constituir em um mecanismo de liberação lenta de clorexidina na cavidade bucal (ROLLA et al. ${ }^{134}, 1970$; 
WAALER; ROLLA ${ }^{170}$, 1985; BRECX et al. $^{34}$, 1993; BARROS; FIORINI ${ }^{19}$, 2000; MATTHIJS; ADRIAENS ${ }^{117}$, 2002).

$\mathrm{Na}$ placa, a clorexidina atua desalojando $\mathrm{O}^{\mathrm{Ca}^{++}}$, um fator de adesividade de microrganismos para a formação de placa dentária, provocando então sua desarticulação, o que constitui um aspecto inibitório de sua formação (AXELSSON ${ }^{8}, 1993$; BARROS; FIORINII ${ }^{19}$, 2000).

Após a realização de um bochecho com clorexidina, a saliva apresenta atividade antibacteriana por até 5 horas (ROLLA; LÖE; SCHIOTT $^{133}$, 1971; ROBERTS; ADDY $\left.{ }^{132}, 1981\right)$, enquanto sua persistência nas superfícies da cavidade bucal diminui a contagem bacteriana por até 12 horas $\left(\mathrm{SCHIOTT}^{145}, 1973\right)$. A clorexidina adsorvida às superfícies bucais é liberada lentamente na forma ativa. Aproximadamente $30 \%$ do agente são retidos na cavidade oral após o bochecho com $10 \mathrm{ml}$ da solução a $0,2 \%$ (ARSENIAN; PEREZ; NUNES ${ }^{7}, 1992$; BARROS et al. ${ }^{21}, 1998$ ).

Os autores CARVALHO et al. ${ }^{40}, 1991$, afirmaram que o efeito residual da clorexidina é de aproximadamente 48 horas, sendo que após este período, a microbiota retorna aos níveis pré-existentes e a placa inicia seu curso normal de formação. A clorexidina atua na diminuição tanto do índice gengival, quanto o de placa. Para o controle de placa subgengival, podem ser feitas irrigações locais com solução de clorexidina em concentrações variando de 0,02\% a 0,2\% (FEIST; MICHELI; SARIAN ${ }^{61}$, 1989; CARVALHO et al. $\left.^{40}, 1991\right)$. Entretanto, a clorexidina não controla eficazmente a placa subgengival (BELLINI et al. $\left.{ }^{27}, 1980\right)$.

ROLLA; MELSEN ${ }^{135}, 1975$, sugeriram alguns mecanismos pelos quais a clorexidina inibe a formação de placa dentária: a) unindo-se aos grupos ácidos aniônicos das glicoproteínas salivares, reduzindo assim a formação de película adquirida e colonização da placa dentária; b) unindo-se às bactérias salivares e interferindo com sua adsorção aos dentes; e c) precipitando os fatores de aglutinação da saliva. Posteriormente, em 1988, JENKINS; ADDY; WADE ${ }^{96}$ concluíram que a ação antiplaca da clorexidina ocorreria como um resultado do efeito bactericida na hora da aplicação, seguido por um prolongado efeito bacteriostático. 
A clorexidina pode ser aplicada de diversas maneiras, dependendo das necessidades individuais do paciente. As mais comuns são bochechos, géis, vernizes, sprays, chips e dentifrícios (LÖE; SCHIOTT ${ }^{107}$, 1970; FEIST; MICHELI; SARIAN ${ }^{61}$, 1989; TORRES ${ }^{162}$, 2000; SREENIVASAN; GAFFAR ${ }^{159}$, 2002).

No Brasil, seu uso é mais freqüente na forma de solução para bochecho, com concentração de $0,12 \%$ (CARVALHO et al. ${ }^{40}, 1991$ ).

A clorexidina em gel é outra apresentação do produto e pode ser formulada em concentrações variando de $0,2 \%$ a 2,0\%. O gel permite a aplicação tópica e é bastante indicado para controle da placa em situações em que a pessoa não consegue fazer o bochecho, como em pacientes hospitalizados que não saem do leito e pacientes especiais. SMITH et al. ${ }^{154}$, 1994, testaram um gel de clorexidina a 1\% em comparação com outros dentifrícios comercialmente disponíveis e encontraram reduções significantes na formação de placa após 6 semanas no grupo que utilizou o gel.

Outro método de controle de placa subgengival é a instalação de um liberador controlado (chip) biodegradável (gelatina hidrolizada) de clorexidina após a raspagem e alisamento da raiz, pois, além de atuar sobre a placa, ajuda a reduzir a profundidade de sondagem (JEFFCOAT et al. ${ }^{91}, 1998$; MACHADO et al. ${ }^{112}$, 2002). Um uso menos difundido é a aplicação de verniz de clorexidina em fissuras de esmalte. SCHAEKEN; VAN DER HOEVEN; VAN DER KIEBOOM ${ }^{141}, 1994$, usaram o verniz com $40 \%$ de clorexidina e obteve, dois dias depois, diminuição acentuada dos estreptococos do grupo mutans em fissuras previamente selecionadas.

A natureza catiônica da clorexidina faz com que ela interaja com alguns detergentes e certos componentes aniônicos contidos nos dentifrícios. A clorexidina também pode ser inativada na presença de fosfatos, sulfatos além da inibição competitiva que é verificada na presença de cálcio (BARKVOLL; ROLLA; SVENDSEN ${ }^{16}$, 1989; VAN GRUNSVEN, CARDOSO $^{165}$, 1995). Quando é indicado o uso de bochechos com soluções de clorexidina, ou mesmo sua aplicação em outros veículos, recomenda-se 
que o procedimento seja realizado 30 minutos após a escovação, ou usada fora dos horários de escovação (CIANCIO ${ }^{45}, 1995$; SANTOS $\left.{ }^{139}, 2003\right)$.

\subsubsection{Toxicologia e efeitos colaterais}

A segurança no uso da clorexidina, verificada através da falta de observação de efeitos adversos sistêmicos significativos ou locais não reversíveis, tem sido comprovada. AZEVEDO et al. ${ }^{11}$, 1996, observaram experimentalmente a ingestão continuada de digluconato de clorexidina a 0,06\%, 0,12\% e 0,24\% e água, por 43 ratos Wistar. Somente a solução a $0,24 \%$ causou alterações de peso e ingestão alimentar nos animais, não provocando nenhum outro efeito adverso. As concentrações de 0,06\% e 0,12\% não provocaram modificações nos parâmetros avaliados (peso corporal, ingestão de alimentos, glicemia, hematócrito e desempenho comportamental).

De acordo com GJERMO ${ }^{70}, 1978$; GJERMO ${ }^{71}, 1989$, a quantidade ingerida de clorexidina é excretada pelas vias normais, sendo que a pequena porcentagem retida no organismo não lhe é tóxica. Do ponto de vista toxicológico, o emprego da clorexidina pode ser considerado sem risco (RINDOM-SCHIÖTT; LÖE; BRINER ${ }^{130}$, 1976; BASTOS; LOPES; RAMIRES ${ }^{24}$, 2001).

Testes de segurança em relação aos efeitos agudos e crônicos dessa substância mostraram níveis extremamente baixos de toxicidade local e sistêmica e não se observaram alterações teratogênicas (NEIDLE; YAGELA ${ }^{121}$, 1991).

Estudos longitudinais comprovam a eficácia clínica da clorexidina e, estudos microbiológicos demonstram não haver resistência bacteriana quando de sua utilização (LÖE et al. ${ }^{106}$, 1976; BRINER et al. ${ }^{36}, 1980$; SREENIVASAN; GAFFAR ${ }^{159}$, 2002; SANTOS ${ }^{139}$, 2003).

Experimentos indicaram que a penetração da clorexidina na mucosa e na gengiva é mínima (LINDHE et al. ${ }^{104}, 1970$; MAGNUSSON; HEYDEN ${ }^{114}$, 1973; HAUGEN; JOHANSEN ${ }^{85}$, 1975). Outros estudos mostraram que a 
clorexidina não provoca nenhuma irritação quando aplicada sobre lesões, além de ajudar na cicatrização de feridas abertas (HENNESSEY ${ }^{88}$, 1973; HAMP; ROSLING; LINDHE ${ }^{84}$, 1975; BARLETTA; ALIVERTI; BUTTA ${ }^{17}$, 1977).

Não há evidências de que a aplicação tópica de clorexidina determine desenvolvimento de tumores (BASTOS; HEINTZE ${ }^{25}$, 1996) nem há relatos de aumento de incidência de câncer, após mais de 20 anos de uso da droga na Europa (BASRANI et al. ${ }^{22}$, 2002).

A clorexidina é pobremente absorvida pelo trato gastrointestinal. Quando ingerida, 90\% dessa droga é excretada nas fezes e o restante é eliminado por via urinária (CASE ${ }^{41}, 1977$; BONESVOLL ${ }^{29}, 1977$; PUPPIN FILHO; FEITOSA; GANHOTTO ${ }^{129}$, 2001). A clorexidina absorvida não se acumula no corpo e não é metabolicamente alterada em produtos perigosos, como a paracloroanilina, a qual não foi detectada na urina de animais e homens, quando de sua utilização (WINROW ${ }^{171}$, 1973; PUPPIN FILHO; FEITOSA; GANHOTO ${ }^{129}$, 2001).

SCHIOT; LÖE; BRINNER ${ }^{146}, 1976$, afirmaram que não houve efeitos colaterais sistêmicos em estudo realizado em indivíduos que utilizaram 10 $\mathrm{mL}$ de clorexidina a 0,2\%, durante dois anos. Assim como MACKENZIE et al. ${ }^{113}, 1976$, que, após a avaliação de biópsias gengivais e palatais em pacientes que usaram clorexidina por mais de um ano, não encontraram diferenças entre os grupos no que diz respeito ao grau de ceratinização, camadas celulares e à espessura do estrato córneo.

A clorexidina apresenta alguns efeitos colaterais decorrentes de um longo período de utilização, tais como: a formação de manchas superficiais nos dentes, língua e mucosa; alteração no paladar, principalmente para o sal; gosto desagradável e sensação de queimação, irritação, descamação das mucosas (MANDEL ${ }^{115}$, 1994). CIANCIO ${ }^{45}, 1995$ e ANDERSON et al. ${ }^{6}$, 1997, acrescentam ainda o efeito de um maior acúmulo de cálculo, ao contrário de BASSIOUNY; GRANT ${ }^{23}, 1975$ e SANZ et al. ${ }^{140}, 1994$.

O manchamento é o efeito colateral mais comum de se observar quando da utilização deste produto (DOLLES; ERIKSEN; GJERMO ${ }^{55}, 1979$; 
GREENSTEIN; BERMANT; JAFFIN ${ }^{79}$, 1986; CARVALHO, et al. ${ }^{40}, 1991$; YATES et al. ${ }^{169}, 1993$; Cury ${ }^{47}, 1999 ;$ SANTOS $\left.^{139}, 2003\right)$. O aparecimento de manchas de coloração marrom ou amarelo escuro pode ocorrer devido às reações de polimerização de compostos da placa dentária, ou por desnaturação de proteínas da película adquirida levando ao aparecimento de grupos sulfídricos que reagem com metais introduzidos na cavidade bucal originando os sulfetos corados ou, ainda, devido às reações com cetonas e aldeídos da dieta (ALSTAD; ZACHRISSON ${ }^{5}$, 1979; ADDY; MORAN², 1985). A pigmentação é exacerbada por cromógenos contidos em diversos tipos de alimentos, particularmente bebidas como chá, vinho tinto e café, os quais interagem com a clorexidina (ALSTAD; ZACHRISSON ${ }^{5}$, 1979; ADDY; MORAN $^{2}, 1985$; ELLINGSEN; ROLLA; ERIKSEN $\left.{ }^{58}, 1982\right)$.

ELLINGSEN; ROLLA; ERIKSEN ${ }^{58}$, 1982, relataram que essa pigmentação está relacionada com a concentração do agente antimicrobiano.

Ressalta-se que as manchas extrínsecas ao esmalte dentário ocorrem na película adquirida adsorvida aos dentes, sendo removidas por profilaxia ou por agentes oxidantes $\left(C U R Y^{47}, 1999\right)$. Uma vez cessado o uso do produto, desaparecem os sintomas (GJERMO ${ }^{70}, 1978$; CARVALHO et al. ${ }^{40}$, 1991; FAYLE; DUGAL; WILLIAMS ${ }^{60}$, 1992; DELIBASE; SARACOGLU; KESKIN $\left.^{50}, 2002 ;\right)$.

Pesquisas vêm sendo conduzidas para tentar reduzir a magnitude do manchamento causado pela clorexidina. A adição de agentes oxigenantes à utilização da clorexidina parece representar um passo adiante para atingir esse objetivo (GRÜNDEMANN et al. ${ }^{82}, 2000$; PILLON ${ }^{128}, 2001$ ), havendo a necessidade de mais estudos sobre esse aspecto.

\subsection{Pacientes em tratamento ortodôntico}

\subsubsection{Observações sobre o tratamento ortodôntico}


Atualmente, a utilização de aparelhos fixos está bastante difundida, inclusive em pacientes adultos (BOYD; BAUMRIND ${ }^{32}$, 1992; HEINTZE ${ }^{86}$, 1996). Devido ao declínio da prevalência da cárie dentária, a população passou a perder menos dentes e, juntamente com a miscigenação racial e a melhora na utilização de métodos preventivos, o apinhamento dentário tornou-se um problema estético e oclusal comum, o que acaba por aumentar a procura por tratamento ortodôntico. (HEINTZE ${ }^{86}$, 1996; BASTOS; HENRIQUES; OLYMPIO ${ }^{26}$, 2001; MATOS ${ }^{116}$, 2003; OLYMPIO et al. ${ }^{124}$, 2004).

Uma das grandes dificuldades evidenciadas na Ortodontia tem sido a manutenção de uma correta higienização bucal durante o tratamento. A presença de bráquetes, bandas e demais acessórios funcionam como retentores adicionais de placa dentária, podendo levar à desmineralizações do esmalte, causando manchas brancas, cáries dentárias e gengivites. (FELIU ${ }^{62}$, 1982; UETANABARO; MARTINS; ANDRADE ${ }^{163}, 1984$; HEINTZE ${ }^{86}$, 1996; TAMBURUS; BAGATIN; NETTO ${ }^{161}$, 1998; GLANS; LARSSON; OGAARD ${ }^{76}, 2003$; DERKS et al. $.^{53}, 2004$ ).

É particularmente difícil manter uma higiene bucal aceitável quando bandas, fios e ligaduras estão presentes (LUNDSTRON; HAMP ${ }^{111}$, 1980). No entanto, as iatrogenias ocorrem devido ao despreparo prévio dos pacientes antes da instalação do aparelho ortodôntico e da falta de reforço e motivação durante o tratamento.

Segundo HEINTZE ${ }^{86}$, 1996, um tratamento com aparelhos fixos é uma intervenção grave no ambiente da cavidade bucal. Os acessórios ortodônticos constituem a base para um risco elevado de cárie dentária e periodontite.

Estudos microbiológicos têm determinado que, após a colocação do aparelho ortodôntico fixo, ocorrem aumentos significantes do número de bactérias, principalmente os lactobacilos e os estreptococos, sujeitando o ambiente bucal a um desequilíbrio e possibilitando o aparecimento de doenças (BALENSEIFEN; MADONIA ${ }^{14}$, 1970; SHEIE; ARNEBERG; KROGSTAD ${ }^{142}$, 1984; DIAMANTI-KIPIOTI; GUSBERTI; LANG ${ }^{54}$, 1987). 
Assim, o sucesso do tratamento ortodôntico está em corrigir a oclusão da maneira mais satisfatória possível, sem, contudo, alterar a higidez préexistente dos dentes e tecidos de suporte. Caso contrário, os benefícios do tratamento podem ser questionados (TAMBURUS; BAGATIN; NETTO ${ }^{161}$, 1998)

O paciente com aparelhos fixos tem que ser incentivado a cuidar de sua cavidade bucal atenciosamente, pois a higiene, nestes casos, é difícil. Enquanto a região problemática nos dentes com bandas está localizada no lado cervical da banda; nos dentes com bráquetes, as superfícies críticas são aquelas nos lados mesial e distal da base do bráquete. Estas superfícies estão localizadas na "sombra" do arco e são de difícil acesso para as cerdas da escova (HEINTZE ${ }^{86}, 1996$ ).

Nos pacientes com aparelho fixo, uma limpeza perfeita dos dentes demora, pelo menos dez minutos, o que exige muito cuidado e disciplina. $O$ tratamento preventivo continua sendo a arma mais eficaz no combate aos problemas dentários. Não há dúvida de que a única proposta viável para a diminuição desses problemas é a motivação mediante conscientização e educação do paciente, que passa assim a exercer um papel ativo nos programas preventivos (HEINTZE ${ }^{86}, 1996$, MATOS $^{116}, 2003$ ).

Face aos possíveis e, não raros, efeitos iatrogênicos causados pelo tratamento ortodôntico, vários autores concordam ser indispensável a instituição de métodos preventivos para todos os pacientes submetidos à terapia ortodôntica (ALEXANDER; JACOBS; TURPIN ${ }^{4}$, 1977; SCHWANINGER; SCHWANINGER ${ }^{147}$, 1979; FELIU ${ }^{62}$, 1982; SILVA FILHO et al. ${ }^{152}$, 1990; DENES; GÁBRIS ${ }^{52}, 1991$; DUBEY; JALILI; GARG ${ }^{57}, 1993$; SOUZA et al. ${ }^{156}$, 1994; GERÔNIMO; TOGASHI; HENRIQUES ${ }^{69}$, 1994; HEINTZE ${ }^{86}$, 1996; BACCHI; PRATES; ATTIZZANI ${ }^{12}, 1997$. É claro que o tipo, freqüência e quantidade das medidas adotadas para a implementação do programa dependerão das características individuais de ambas as partes - profissional e paciente (FELIU ${ }^{62}, 1982$; SOUZA et al. ${ }^{156}$, 1994; BACCHI; PRATES; ATTIZZANI ${ }^{12}$, 1997). 
Quando o monitoramento da placa é instituído ao paciente antes da colocação do aparelho e motivado no transcorrer do tratamento, é possível conseguir que o índice gengival não sofra incremento (BOYD $\left.{ }^{31}, 2000\right)$.

A importância de se instituir um programa de motivação e orientação para o controle mecânico da placa dentária é destacada por vários autores (ZACHRISSON $^{172}$, 1974; SOUZA et al. ${ }^{156}$, 1994; SOUZA; FALCÃO; ARAÚJO ${ }^{157}$, 1999), sendo que o método mais eficiente e simples para o controle da placa dentária se resume no uso da escova e do fio dental (BACCHI; PRATES; ATTIZZANI ${ }^{12}$, 1997; OWENS et al. ${ }^{126}$, 1997; TAMBURUS; BAGATIN; NETTO ${ }^{161}$, 1998). No entanto, nos casos em que o controle de placa pelos métodos mecânicos se torna deficiente, pode-se considerar a prescrição de agentes químicos (MAYERSON ${ }^{118}$, 1996; CURY $^{47}$, 1997; PUPPIN FILHO; FEITOSA; GANHOTO ${ }^{129}$, 2001; MATOS ${ }^{116}$, 2003).

Os métodos químicos são de grande valia, principalmente em pacientes pouco colaboradores ou com higiene bucal deficiente. Os efeitos antiplaca da clorexidina e anticariogênicos do flúor são amplamente comprovados na literatura científica (CHEYNE; RICE ${ }^{44}$, 1942; BALL; BALL ${ }^{15}$, 1967; BUDTZ-JÖRGENSEN; LÖE ${ }^{37}$, 1972; DE LA ROSA; STURZENBERGER ${ }^{49}$, 1976; BARNES et al. ${ }^{18}$, 1976; BARROS, et al. ${ }^{20}$, 1976; FEIST; MICHELLI; SARIAN ${ }^{61}$, 1986; CASTELLANOS ${ }^{42}$, 1987; GEIGER et al. ${ }^{68}$, 1988; BRIGHTMAN et al. ${ }^{35}$, 1991; GARIB et al. ${ }^{67}$, 1997; LUCAS; LUCAS $\left.{ }^{110}, 1997\right)$.

\subsubsection{O uso da clorexidina em ortodontia}

Nos pacientes que fazem uso de aparelhos ortodônticos fixos, podese observar, muitas vezes, que o controle efetivo da placa dentária, através de métodos mecânicos sofre algumas limitações (HEINTZE ${ }^{86}, 1996$; STEFANI; LIMA ${ }^{160}$, 1996; GARIB et al. ${ }^{67}$, 1997). Dessa forma, o importante papel do agente químico antibacteriano na melhora da saúde bucal deve ser considerado observando cada caso. 
É pertinente a prescrição de agentes antimicrobianos para pacientes em tratamento ortodôntico que apresentam gengivite. Segundo os autores LANG; BRECX ${ }^{101}, 1986$, durante a fase ativa do tratamento ortodôntico, o uso de um agente químico que reduz o acúmulo de placa fornece um benefício clínico satisfatório.

Para tanto, BRIGHTMAN et al. ${ }^{35}, 1991$, propuseram-se a determinar a eficácia do bochecho de gluconato de clorexidina na redução da ocorrência de gengivite, em adolescentes sob tratamento ortodôntico. No grupo experimental participaram 16 voluntários e no grupo controle, 18, com idades variadas de 11 a 17 anos. Avaliou-se o índice gengival, índice de placa e sangramento gengival, tanto na coleta inicial de dados (baseline), como após 6 e 12 semanas de experimento, Os indivíduos do grupo experimental (clorexidina - Peridex $^{\circledR}$ ) apresentaram reduções estatisticamente significantes após os três meses de pesquisa quando comparados ao grupo placebo, considerando o índice de placa, índice gengival e sangramento gengival, com reduções percentuais de: 64,9\%, 60,0\% e 77,2\%, respectivamente. Os autores concluíram que o Peridex (clorexidina a 0,12\%, 2 vezes ao dia), em combinação com a remoção mecânica da placa, provou ser um importante agente terapêutico no controle da inflamação gengival, sangramento e acúmulo de placa em pacientes ortodônticos com gengivite estabelecida.

Segundo HEINTZE ${ }^{86}$, 1996, a prevenção básica sugerida para pacientes ortodônticos é composta pela execução dos seguintes procedimentos: higiene bucal com dentifrício fluoretado, escova interproximal e Superfloss ${ }^{\circledR}$, remoção profissional da placa, aplicação do verniz de clorexidina nas superfícies de risco (2-4 vezes ao ano) e fortalecimento da conscientização sobre dieta adequada.

Quando é detectada uma alta contagem de Streptococcus mutans, o tratamento antibacteriano com clorexidina é indicado. Para diminuir o número de $S$. mutans das superfícies dentárias, de uma maneira eficiente e duradoura, um gel de clorexidina 1\% gera bons resultados. Este gel é aplicado através de moldeiras flexíveis individuais. Mas, uma única aplicação 
não se mostra eficiente. Foi observado que, na maioria dos pacientes, o gel deve ser aplicado seis vezes durante dois dias, para alcançar o objetivo do tratamento. O paciente é orientado a fazer movimentos de mastigação com as moldeiras (cobertas de gel), durante cinco minutos, para que o gel seja, então, bem difundido, penetrando nas áreas proximais e nas fissuras. Entre as aplicações deve-se, meticulosamente, enxaguar as moldeiras com água. Como alternativa, o próprio paciente pode aplicar o gel nas moldeiras, diariamente, durante um período de dez dias. Porém, deve-se atentar ao fato de que a escovação com gel de clorexidina é menos efetiva. A desvantagem deste procedimento, além de ser demasiadamente demorado, baseia-se no fato de que o paciente age fora do controle do ortodontista. Através desses métodos, pode-se na maioria dos casos, reduzir drasticamente a contagem de S. mutans. Após dois até quatro meses, observa-se freqüentemente uma recolonização dos dentes, a qual começa nos molares e atinge depois os pré-molares e os incisivos. Durante a fase ativa do tratamento, as superfícies devem ser tratadas regularmente com clorexidina, pois sempre se deve levar em consideração a possível ocorrência de uma diferenciação na placa bacteriana para uma placa com maior incidência de S. mutans (HEINTZE ${ }^{86}$, 1996).

Foram lançados no mercado alguns vernizes que contêm clorexidina, como por exemplo, o EC $40^{\circledR}$ (Explore), com 40\% de clorexidina na base de Sandarac; Chilorzoin ${ }^{\circledR}$ (Kwwell), com 10\% de clorexidina e Cervitec $^{\circledR}$ (Vivadent) que contém além de $1 \%$ de clorexidina, 1\% de timol, o qual também gera efeitos antibacterianos. Recomenda-se que o verniz seja aplicado somente nas superfícies de risco, ou seja, naquelas em volta das bases dos bráquetes. Os vernizes oferecem a vantagem de liberar clorexidina durante um período prolongado. Assim, o tratamento deve ser repetido em intervalos definidos. No caso do Cervitec ${ }^{\circledR}$, pelo menos a cada três meses; no de EC $40^{\circledR}$, provavelmente duas vezes ao ano. Em um estudo no qual foi aplicado Chilorzoin ${ }^{\circledR}$ quatro vezes antes da colagem dos bráquetes, obteve-se como resultado, que mesmo depois de sete meses, os S. mutans não foram detectados em 11 dos 26 pacientes. No caso do verniz 
EC $40^{\circledR}$, uma única aplicação nas superfícies proximais pode ser suficiente para manter o nível de $S$. mutans até quatro meses abaixo daquele anterior ao tratamento. Nas fissuras, uma só aplicação pôde eliminar os S. mutans junto a 50\% dos pacientes; uma recolonização foi observada apenas depois de 22 semanas. No caso do Cervitec ${ }^{\circledR}$, no entanto, as superfícies dos dentes são recolonizadas mais rapidamente do que com o verniz EC $40^{\circledR}$. Um estudo mostrou que a aplicação do verniz, por duas vezes, nas superfícies proximais, permitiu, após o período de um mês que $50 \%$ delas atingissem o alto índice inicial de S. mutans. Como não há interação entre o verniz de flúor e o verniz de clorexidina, ambos os vernizes podem ser aplicados na mesma sessão de tratamento (HEINTZE $\left.{ }^{86}, 1996\right)$.

STEFANI; LIMA ${ }^{160}, 1996$, realizaram um estudo com a participação de 18 adolescentes portadores de aparelhos ortodônticos fixos, com os primeiros molares superiores e inferiores bandados. Estes voluntários receberam profilaxia profissional, instrução de higiene bucal e foram divididos em dois grupos, um dos quais recebeu aplicações subgengivais, semanais de gel de clorexidina a $0,12 \%$ e o outro aplicações de um gel placebo. Os dois grupos foram examinados uma vez ao mês durante três meses, quando então, foram medidos o Índice Gengival e a profundidade de sondagem. A análise não demonstrou haver diferença estatística significante entre os grupos, mas sim entre os exames baseline e de 90 dias para cada grupo. Com base nos resultados, concluiu-se que o gel de clorexidina não foi mais eficiente que o placebo e que os baixos índices encontrados ao final dos três meses, foram devidos à instrução de higiene oral promovida ao início da pesquisa.

JÚNIOR et al. ${ }^{99}, 1996$, objetivaram avaliar clinicamente durante um período de três meses, os efeitos de bochechos à base de clorexidina a 0,12\% na saúde gengival de pacientes portadores de parelho ortodôntico fixo. Participaram da pesquisa 30 pacientes, cuja faixa etária era de 12 a 18 anos, divididos em grupo de estudo (20 indivíduos) e grupo controle (10 indivíduos). No início do estudo, os pais dos pacientes foram orientados a fiscalizar os bochechos de seus filhos diariamente. Os bochechos eram 
feitos duas vezes ao dia, sendo utilizados $15 \mathrm{~mL}$ de solução a base de clorexidina (Periogard ${ }^{\circledR}$ Colgate) pela manhã e outro à noite, depois da higiene oral, conforme recomendação do fabricante. O grupo controle realizava igualmente os bochechos, utilizando substância placebo. O monitoramento e as verificações clínicas de gengivite foram quinzenais. Os resultados obtidos comprovaram a redução estatisticamente significante do sangramento papilar, no grupo que fez uso da clorexidina em forma de bochechos diários. Concluiu-se que a clorexidina em forma de bochechos é um agente efetivo no combate ao sangramento gengival, não havendo necessidade de prolongar o experimento além de 60 dias, pois a maximização dos benefícios proporcionados pelo uso desta substância no grupo de estudo se deu no $45^{\circ}$ dia.

O objetivo do estudo realizado por GARIB et al. ${ }^{67}, 1997$, foi avaliar a eficácia de bochechos com solução de clorexidina $(0,12 \%)$ e cloreto de cetilpiridínio $(0,05 \%)$ na redução da placa dentária e gengivite, considerando o cloreto de cetilpiridínio isoladamente e associado à clorexidina. Participaram da pesquisa 60 voluntários que utilizavam aparelho fixo, os quais foram divididos em 3 grupos. O Grupo I realizava bochechos diários após a escovação noturna, com $10 \mathrm{~mL}$ da solução de cloreto de cetilpiridínio (Wash ${ }^{\circledR}$ - Abbott), o Grupo II, além de realizarem o bochecho como o grupo I, os pacientes ainda bochechavam $10 \mathrm{~mL}$ de solução de clorexidina (Periogard $^{\circledR}$ - Colgate), a cada 8 dias, por 1 minuto, antes de dormir, e o Grupo III era o controle, os quais bochechavam solução placebo. Considerando que a fase experimental durou 90 dias, realizou-se uma avaliação inicial e uma final do índice de sangramento gengival de cada paciente, enquanto que o índice de placa (PHP) foi avaliado quinzenalmente, em todos os grupos. Concluiu-se que os bochechos empregados levaram a uma redução estatisticamente significante do índice de placa e de sangramento gengival dentro de cada grupo, porém, não houve diferença estatisticamente significante entre os grupos. O cloreto de cetilpiridínio levou a uma redução de $23,6 \%$ do índice de placa e de $55,9 \%$ do índice de sangramento gengival, entretanto, esta substância associada à clorexidina 
levou a uma redução de $52,2 \%$ do índice de placa e de $62,9 \%$ do índice de sangramento gengival. Pela análise global dos resultados deste estudo, houve maior redução do índice de placa dos pacientes colaboradores, quando comparados aos não colaboradores, independentemente do agente utilizado para o bochecho.

Em um estudo clínico realizado por ANDERSON et al. ${ }^{6}, 1997$, observou-se que a administração de bochechos com clorexidina reduziu índices de placa dentária, sangramento gengival e profundidade de sondagem em adolescentes portadores de aparelhos fixos. A descoloração e a formação de cálculo não foram clinicamente significantes nos três meses de duração do estudo.

Para se avaliar a efetividade de enxaguatórios bucais à base de clorexidina no controle da placa bacteriana e gengivite em pacientes ortodônticos, RIVERA; CAVIERES ${ }^{131}$, 1998, selecionaram 90 com idade variando de 11 e 20 anos. Todos os participantes eram portadores de aparelhos ortodônticos fixos e foram divididos em dois grupos. $O$ grupo $A$ utilizou clorexidina a $0,1 \%$ e o $\mathrm{B}$, a $0,2 \%$. O período experimental foi de 8 semanas e, ao fim destas, concluiu-se que as duas concentrações do produto reduziram significativamente a placa bacteriana e gengivite, entretanto, não houve diferenças estatisticamente significantes entre as concentrações.

Em 1999, SOUZA; FALCÃO; ARAÚJO ${ }^{157}$ fizeram uma proposta de orientação para higiene bucal em pacientes ortodônticos. Os autores afirmaram que o importante é remover a placa dentária. O emprego de recursos químicos auxiliares não deve ser indicado uniformemente para todos os pacientes a exemplo dos métodos mecânicos. Uma avaliação de risco à cárie e à doença periodontal deve ser realizada e, a partir desta, algumas recomendações podem ser feitas:

1. Independentemente do risco à cárie: profilaxia e aplicação profissional de flúor fosfato acidulado com intervalos de três meses, associado a bochechos diários de fluoreto de sódio $0,05 \%$. 
2. Risco à cárie alto: adotar as mesmas medidas anteriores, podendo estas ser associadas ao controle químico da placa. Considerando a eficácia da clorexidina, pode-se estabelecer o seguinte esquema: dois bochechos diários com uma solução de clorexidina 0,12 ou $0,2 \%$, durante quinze dias, repetidos trimestralmente enquanto durar 0 tratamento ortodôntico.

3. Finalizando, todos os pacientes devem ser educados quanto à redução do consumo de alimentos ricos em carboidratos, sobretudo de guloseimas, nos intervalos das refeições principais.

Avaliações sobre o risco individual à cárie dentária e à doença periodontal devem ser realizadas pelo ortodontista para delinear as estratégias para a manutenção da saúde bucal durante todo o tratamento. Considerando a eficácia da clorexidina, pode-se estabelecer que, nos casos indicativos de maior risco à cárie e/ou como necessidade de auxiliar do método mecânico de higienização bucal, a posologia de dois bochechos diários com solução de clorexidina $0,12 \%$ ou $0,2 \%$, durante quinze dias, repetidos trimestralmente enquanto durar o tratamento ortodôntico, seria uma maneira viável, eficiente e com efeitos colaterais reversíveis no controle de placa e conseqüente melhora na saúde bucal deste pacientes (FEIST; MICHELI; SARIAN ${ }^{61}$, 1989; CARVALHO et al. ${ }^{40}$, 1991; BRIGHTMAN et al. ${ }^{35}$, 1991; JÚNIOR et al. ${ }^{99}$, 1996; SOUZA; FALCÃO; ARAÚJO ${ }^{157}$, 1999).

Frente às inúmeras possibilidades de uso de clorexidina em odontologia (CARVALHO et al. $^{40}$, 1991; ARSENIAN; PEREZ; NUNES ${ }^{7}$, 1992; HEINTZE ${ }^{86}$, 1996; TORRES ${ }^{162}$, 2000; FERRAZ et al. ${ }^{63}, 2001$; SOARES; ITO; ROCHA BARROS ${ }^{155}$, 2001; BASTOS; LOPES; RAMIRES ${ }^{24}$, 2001; PAVARINA et al. $\left.{ }^{127}, 2003\right)$, recomenda-se que sua utilização seja racional como coadjuvante ao tratamento, analisando as necessidades e condições individuais de cada paciente (CURY $\left.{ }^{47}, 1999\right)$. 


\subsection{Dentifrícios com clorexidina}

A maioria dos estudos realizados com pastas dentárias contendo clorexidina têm sido feitos com dentifrícios experimentais. O efeito do uso de dentifrícios com clorexidina sobre a placa dentária, comparando ao uso de bochechos, é considerado semelhante se, a quantidade total de clorexidina usada for a mesma (BASTOS; LOPES; RAMIRES ${ }^{24}, 2001$ ).

Supõe-se que, quando administrada nos dentifrícios convencionais, a clorexidina interaja com alguns sulfactantes, detergentes e abrasivos contidos nos mesmos, sendo inativada. Há uma competição pelos sítios de retenção na cavidade bucal entre esse agente químico e o cálcio contido nas formulações tradicionais, além do que, discute-se sobre sua efetividade em formulações de dentifrícios, levando em conta a relação custo-benefício de tal aplicação, devido aos efeitos colaterais provocados pela clorexidina, especialmente a impregnação de pigmentos aos dentes (JOYSTONBECHAL $^{98}$, 1992; GUGUSHE; WET, ROJAS-SILVA ${ }^{83}$, 1994; GARIB et al. ${ }^{67}$, 1997; TORRES ${ }^{162}, 2000$ ).

Considerando o fato de que a escovação com dentifrícios é o hábito mais comum de higiene bucal (SHEIHAM ${ }^{151}$, 1970; FRANDSEN ${ }^{65}$, 1986; OWENS et al. $\left.{ }^{126}, 1997\right)$, esta prática pode ser vista como uma forma plausível para introdução de agentes químicos para melhorar a saúde bucal (MURRAY; RUGG-GUNN ${ }^{120}$, 1982; YATES et al. ${ }^{169}$, 1993).

Segundo FLOTRA ${ }^{64}$, 1973, a utilização de dentifrícios contendo clorexidina significa uma aplicação direta do medicamento nas áreas necessárias. $O$ autor afirmou ainda que o efeito antiplaca da clorexidina quando associada à pasta dental não é tão bom quanto ao obtido com o seu emprego em bochecho. Esta atividade reduzida da clorexidina em dentifrícios convencionais tem sido atribuída à inativação ou à competição pelos sítios bucais de retenção entre os íons cálcio e os detergentes aniônicos comumente encontrados em suas formulações (GJERMO; ROLLA $^{75}$, 1971). 
GJERMO; ROLLA ${ }^{74}$, 1970, avaliaram o uso de dentifrícios com clorexidina a $0,6 \%$ e $0,8 \%$, aplicados em moldeiras sobre os dentes para evitar a interferência da ação mecânica da escovação e, constataram uma redução do índice de placa compatível aos resultados obtidos com os bochechos.

RUSSELL; $B A Y^{136}, 1978$, observaram que 3 minutos de escovação diária com dentifrício a base de 1\% de clorexidina, refletiram em uma melhora significante dos índices de placa e gengival em crianças epiléticas e mentalmente retardadas. Entretanto, para a hiperplasia gengival, em específico, essa redução não foi significante. O manchamento extrínseco observado foi menos intenso do que o verificado com a utilização de bochechos com clorexidina.

TORRES ${ }^{162}$, 2000, afirma que os estudos sobre clorexidina em dentifrícios são controversos. Alguns estudos de curta duração demonstraram que houve efeito clínico redutor de placa dentária e gengivite, entretanto, há questionamentos sobre sua utilização neste veículo devido à formação de manchas nos dentes.

Pesquisas com dentifrícios experimentais demonstraram que, dentifrícios com $0,5 \%$ de clorexidina, apresentaram ação anti-placa e antibacteriana, no entanto, foram menos efetivos que os bochechos com clorexidina a 0,2\% (ADDY et al. ${ }^{1}$, 1989; JENKINS; ADDY; NEWCOMBE, ${ }^{95}$ 1990).

DOLLES; ERIKSEN; GJERMO ${ }^{55}$, 1979, realizaram um estudo duplo cego para verificação dos possíveis efeitos do fúor ( $\mathrm{NaF}$ ) no manchamento extrínseco do esmalte, causado pelo uso prolongado da clorexidina (1\%), após 1 e 2 anos de uso do produto. Através dos exames, foi verificado que houve menor formação de manchas quando a clorexidina foi aplicada juntamente com o flúor. Esta observação foi detectada no primeiro ano de estudo. No final dos 2 anos de experimento, essa diferença não foi estatisticamente significante.

JENKINS; ADDY; NEWCOMBE ${ }^{93}$, 1993, afirmaram que a associação de F com clorexidina em dentifrícios não provocou a inibição da clorexidina e 
que, o manchamento dentário verificado é uma prova de que a disponibilidade da substância no dentifrício existiu. Nesse estudo, a introdução de $1 \%$ de clorexidina aos dentifrícios promoveu melhora nos índices de placa, gengival e sangramento, semelhantemente às verificadas nos bochechos com clorexidina a 0,2\%. No entanto, a redução de microrganismos na cavidade bucal foi maior quando da utilização de bochechos.

DOLLES; GJERMO ${ }^{56}$, 1980, avaliaram por 2 anos os efeitos do uso caseiro de dentifrícios contendo clorexidina (2\%) ou flúor (0,1\% NaF) e uma combinação de flúor $(0,1 \% \mathrm{NaF})$ com clorexidina $(2 \%)$ no combate à cárie dentária e gengivite em 91 escolares de 13 a 15 anos de idade. As escovações eram realizadas duas vezes ao dia, por 2 minutos. O grupo que utilizou o dentifrício com $\mathrm{F}$ e clorexidina apresentou menor índice de cárie dentária. O incremento de cárie nos 3 grupos não apresentou diferenças estatisticamente significantes. As condições gengivais melhoraram nos três grupos.

Em um estudo clínico realizado por SANZ et al. ${ }^{140}$, 1994, o dentifrício experimental (clorexidina a $0,4 \%$ e $0,34 \%$ de zinco) contribuiu significantemente para a melhora da higiene bucal, tanto em relação à placa dentária como à gengivite e sangramento, ocasionando menos manchas do que as encontradas no grupo que utilizou bochechos com clorexidina a 0,12\%. O acúmulo de cálculo não aumentou significantemente quando comparado ao grupo controle. Conclui-se que o dentifrício testado pode ser visto como uma alternativa promissora no uso de substâncias eficazes na redução de placa e gengivite, e com efeitos colaterais mínimos.

Em um estudo de gengivite experimental, JENKINS; ADDY; NEWCOMBE ${ }^{94}$, 1993, verificaram que a formulação de dentifrício com clorexidina a 1\% e 1000 ppm F (NaF) produziu reduções estatisticamente significantes de placa e gengivite, comparando-se com o grupo controle. Posteriormente, YATES et al. ${ }^{169}$, 1993, se propuseram a avaliar clinicamente os efeitos de dentifrícios com clorexidina a 1\%, adicionados ou não 1000 
ppm F (NaF) - previamente testados por JENKINS; ADDY; NEWCOMBE ${ }^{94}$, 1993 - sobre a placa, gengivite, sangramento, cálculo e manchamento dentário, em 6 meses de acompanhamento. A amostra foi constituída por 297 participantes com idade entre 18 e 61 anos. Os pacientes foram instruídos sobre a utilização dos dentifrícios 2 vezes ao dia. Os índices de placa, gengival e sangramento melhoraram em todos os grupos, entretanto, nos grupos que usaram clorexidina com/sem flúor os resultados foram estatisticamente melhores do que os obtidos no grupo controle. Houve aumento significante de manchas e cálculo nos pacientes dos grupos da clorexidina com/sem flúor. Os maiores benefícios alcançados foram verificados nos exames após 6 semanas de estudo e mantiveram-se inalterados até o final do estudo. Os autores relataram que esses dentifrícios testados (clorexidina 1\% e clorexidina 1\% com F) podem ser utilizados para as mesmas aplicações clínicas dos outros produtos a base de clorexidina. A aparente compatibilidade verificada do F com a clorexidina, torna-se um fator importante na prevenção da cárie dentária, através do efeito sinérgico dessas substâncias.

No que diz respeito aos efeitos sobre a microbiota bucal, os dentifrícios com clorexidina a 1\%, testados por um período de 6 meses, promoveram reduções dos microrganismos aeróbios e aneróbios (MAYNARD et al. ${ }^{119}, 1993$ ).

Em 1994, GUGUSHE; WET; ROJAS-SILVA ${ }^{83}$, verificaram que um dentifrício experimental com $1 \%$ de clorexidina foi capaz de reduzir significantemente o índice de placa durante o período de tratamento de 12 semanas. Apesar da expressiva redução do índice gengival, não houve diferença estatística entre os grupos. Os benefícios máximos foram verificados nos exames de 6 semanas de pesquisa.

De acordo com NEWMAN ${ }^{122}$, 1986, a introdução de antimicrobianos nos dentifrícios tem o objetivo de melhorar a eficácia da escovação dentária e promover o benefício antiplaca nas áreas da cavidade bucal que foram "esquecidas" nos procedimentos de higiene bucal. 
PROPOSICÃO 


\section{ProposiçÃo}

Embora haja uma vasta literatura comprovando a ação da clorexidina sobre a placa dentária, gengivite e cárie dentária, sua utilização tendo o dentifrício como veículo de administração é controversa. Além disso, pacientes submetidos ao tratamento ortodôntico fixo podem, muitas vezes, apresentar dificuldades na manutenção de uma higiene bucal satisfatória. Portanto, esta pesquisa teve como objetivos:

- Analisar os efeitos de dentifrícios contendo clorexidina, adicionados ou não de flúor, na redução de placa dentária, gengivite e sangramento gengival em pacientes sob tratamento ortodôntico;

- Verificar a ocorrência de um efeito muito comum da clorexidina: o manchamento extrínseco do esmalte dentário;

- Verificar a prevalência de cálculo dentário;

- Verificar se a utilização do NaF juntamente com a clorexidina interfere no desempenho da mesma. 
MATERIAL E MÉTODOS 


\section{Material e Métodos}

\subsection{MATERIAL}

\subsubsection{Seleção dos participantes da pesquisa}

Após aprovação do Comitê de Ética em Pesquisa com Seres Humanos da FOB-USP (Processo $n^{0 .}$ 107/2004) foram contactados 128 pacientes da Clínica de Ortodontia da FOB-USP (mestrado e especialização) e do curso de Especialização em Ortodontia da APCD-Bauru através da consulta aos ortodontistas dos respectivos cursos, bem como aos prontuários dos pacientes. Como critérios de inclusão iniciais, definiu-se: estar sob tratamento ortodôntico fixo programado para, pelo menos, 6 meses além do início da pesquisa, apresentar-se com dentadura permanente e possuir algum telefone para contato.

Através de telefonemas a estes pacientes e/ou seus respectivos responsáveis realizou-se uma breve explicação sobre a pesquisa e um convite para que eles pudessem participar de uma palestra no salão nobre da Faculdade de Odontologia de Bauru para um melhor esclarecimento acerca do projeto e também para a obtenção dos termos de consentimento livre e esclarecido para a participação na pesquisa (ANEXOS 1, 2 e 3).

Além disso, nos telefonemas, algumas perguntas forma feitas sobre a saúde geral dos possíveis voluntários, obedecendo assim outros critérios de inclusão, tais como: apresentar um bom estado de saúde geral (por ex. não apresentar doenças reumáticas, diabetes mellitus), não ter ingerido antimicrobianos sistêmicos nos três meses anteriores ao início da pesquisa, não estar grávida e não ser fumante.

Após a realização da reunião inicial, do número total de pacientes contactados, permaneceram na pesquisa 85 pacientes, os quais foram submetidos aos exames baseline para verificar se apresentavam um grau mínimo de gengivite, verificado através da obtenção do Índice Gengival 
(LÖE; SILNESS ${ }^{108}, 1963$ ). No delineamento da amostra, definiu-se que o número total de participantes deveria estar entre 80 a 90 indivíduos.

\subsection{MÉTODOS}

\subsubsection{Protocolo do estudo}

Este estudo clínico foi randomizado e cego. Os voluntários foram alocados nos grupos de estudo observadas as características de idade, gênero, grau de gengivite e índice de placa (ANEXO 4).

Após o balanceamento dos grupos [Grupo A (n=29), Grupo B $(n=28)$ e Grupo C ( $n=28)$ ], os participantes, de acordo com seus respectivos grupos, receberam os dentifrícios. O grupo A recebeu o dentifrício Sorriso Fresh Red Mint ${ }^{\circledR}, 1100$ ppm F (NaF) - Kolynos do Brasil Ltda, sendo considerado como o grupo controle positivo. Os grupos B e C, receberam dentifrícios experimentais similares ao dentifrício $A$ com as seguintes exceções: nenhum dos dois teve em sua composição lauril sulfato de sódio, fosfatos ou outras substâncias conhecidas por competir com a clorexidina. No dentifrício B foram adicionados 1100 ppm $F(\mathrm{NaF})$ e clorexidina 0,95\% (digluconato de clorexidina) - $F G M \otimes$, Joinville. Ao dentifrício $C$ foi adicionado somente clorexidina 0,95\% (digluconato de clorexidina) - $F G M \circledR$, Joinville.

Os dentifrícios passaram previamente por uma análise laboratorial para que fossem aferidas as concentrações de flúor total (FT), solúvel (FS) e iônico (FI) em cada um. Dois dentifrícios de cada grupo foram analisados em duplicata. Em cada grupo de estudo, somente produtos de um mesmo lote foram utilizados. Mesmo que o dentifrício do grupo C não apresentasse F em sua composição, amostras do mesmo foram avaliadas, sabendo-se que é comum haver uma contaminação. Os dentifrícios apresentaram, respectivamente, as seguintes concentrações de $\mathrm{FT}, \mathrm{FS}$ e $\mathrm{Fl}$ : grupo A (1115,02 ppm F; 1110,65 ppm F; 1105,58 ppm F), grupo B (1119,71 ppm F; 1121,94 ppm F; 1071,33 ppm F) e grupo C (23,55 ppm F; 20,94 ppm F; 25,75 ppm F). 
Foram passadas orientações verbais e por escrito para que nenhum outro produto químico de higiene bucal fosse utilizado durante 0 experimento. Orientou-se para que as escovações fossem realizadas três vezes ao dia, por 2 minutos, com uma quantidade que cobrisse, longitudinalmente, todas as cerdas da escova dentária (ANEXO 5). Dessa forma, aproximadamente $1,5 \mathrm{~g}$ de dentifrício seriam usados em cada escovação. Foram fornecidos aos participantes no início da pesquisa 1 escova dental da marca Dentil plus (macia), passa-fio e fio dental. Solicitouse aos pacientes que comunicassem à pesquisadora o nome do medicamento e o período de uso, caso os mesmos necessitassem ingerir algum antibiótico durante o decorrer da pesquisa.

O dentifrício foi fornecido à medida em que o paciente necessitasse, sendo registrada a quantidade de tubos que cada paciente utilizou durante $o$ experimento, através da devolução dos tubos usados no momento da reposição. Uma secretária contratada para esta pesquisa ficou responsável pela reposição dos dentifrícios e pelo agendamento dos pacientes para os exames.

As orientações referentes ao protocolo de utilização dos dentifrícios foram reforçadas nos dias agendados para os exames e através de telefonemas quinzenais realizados pela pesquisadora.

Os pacientes receberam alguns números de telefones, os quais poderiam ser acessados caso tivessem alguma dúvida ou precisassem, por algum motivo, repor seus dentifrícios fora do dia agendado.

No início da pesquisa os voluntários preencheram um questionário inicial sobre seus hábitos de higiene e alimentares (ANEXO 6). Nos exames de 6 e 12 semanas foram aplicados questionários de acompanhamento (ANEXO 7) com o objetivo de acessar a adesão dos voluntários ao protocolo proposto pela pesquisa, além de verificar possíveis alterações na cavidade bucal, por eles observadas.

Durante o decorrer da pesquisa, mais especificamente entre o período de exames baseline e de 6 semanas, houve perda de 2 pacientes do Grupo 
$A$, chegando-se ao final do experimento com 83 voluntários: Grupo $A=27$; Grupo B $=28$ e Grupo C = 28 voluntários (ANEXO 4).

\subsubsection{Exames clínicos}

Todos os voluntários receberam profilaxia profissional após os exames baseline e ao final do estudo. Os exames clínicos foram realizados nos tempos: baseline, 6 e 12 semanas de utilização dos dentifrícios.

$\mathrm{O}$ reforço sobre a correta higiene bucal foi feito no final dos exames baseline e de 6 semanas, através de explicações sobre a importância da escovação com o respectivo dentifrício e o uso do fio dental. Não foi realizada escovação supervisionada em momento algum.

Duas examinadoras previamente treinadas (OPPERMANN; RÖSING ${ }^{125}$, 2001) por um profissional especializado da área de Periodontia da FOBUSP, realizaram os exames em consultório particular, sendo que, uma das examinadoras ficou responsável por verificar o índice de manchas e o de tártaro, enquanto a outra verificou os índices gengival, de sangramento e de placa. Os exames foram feitos sob iluminação artificial e ar comprimido, utilizando-se sondas propostas pela OMS (Trinity Ind. e Com. Ltda.) e espelhos clínicos planos. Para a evidenciação da placa dentária supragengival, aplicou-se fucsina a $2 \%$. Os exames individuais tiveram uma duração média de 30 minutos e foram os seguintes:

(1) Índice de manchas (SHAW; MURRAY ${ }^{150}$, 1977) modificado nessa pesquisa para adaptação dos registros do manchamento no caso de pacientes com aparelhos ortodônticos fixos. Nesse Índice são registradas manchas extrínsecas por área das superfícies vestibulares e linguais de incisivos superiores e inferiores permanentes. Utiliza-se espelho clínico plano, luz artificial e ar comprimido para verificar a presença de manchas. Todas as áreas com manchamento extrínseco no esmalte são desenhadas pelo examinador na ficha do paciente. O número de quadrados que foram 
pintados são contados, obtendo-se o valor do índice de machamento final do paciente. Se algum quadrado não estiver totalmente pintado, somente aqueles que tiveram sua marcação excedendo a metade é que serão contados.

(2) Códigos e critérios para verificar a presença de tártaro utilizados no Índice de Higiene Oral Simplificado (GREENE; VERMILLOIN ${ }^{80}$, 1964), medindo a existência de cálculo nas superfícies vestibulares e linguais de todos os dentes permanentes presentes na cavidade bucal do paciente. Cada superfície recebe separadamente um código de 0 a 3. O exame é feito com espelho clínico e sonda. Trata-se de um subíndice do IHOS e o resultado é obtido a partir da soma dos códigos de cada dente dividida pelo total de dentes examinados. Nesta pesquisa, optou-se pelo exame de todos os dentes, considerando até os $2^{\text {os. }}$ molares (exceto dentes bandados), e não somente os dentes preconizados no IHOS. Os códigos e critérios são: 0 - inexistência de tártaro.

1 - tártaro supragengival em não mais que $1 / 3$ da superfície exposta do dente.

2 - tártaro supragengival cobrindo mais que $1 / 3$, mas não mais que 2/3 da superfície exposta em torno da região cervical.

3 - tártaro supragengival cobrindo mais que 2/3 da superfície da coroa ou faixa contínua e espessa de tártaro subgengival.

$\mathrm{X}$ - dente inexistente/excluído.

(3) Índice gengival (LÖE; SILNESS ${ }^{108}$, 1963) para indicar as condições de saúde dos tecidos gengivais e o grau de inflamação. Os dentes são examinados individualmente após sondagem e divididos em 4 faces - vestibular, lingual, mesial e distal - atribuindo-se um valor de 0 a 3 para cada face. Somam-se os valores das 4 faces e divide-se por 4 para obtenção do índice gengival do dente. É feita então a soma dos índices de cada dente e, dividindo o total obtido, pelo número de 
dentes examinados, chega-se ao IG individual. Nessa pesquisa, todos os dentes permanentes presentes (até os $2^{\text {os. }}$ molares) foram examinados. Valores do IG variando de 0,1 a 1,0 representam gengivite leve; de 1,1 a 2,0 gengivite moderada e 2,1 a 3,0 gengivite severa. Os códigos e critérios são:

0 - ausência de inflamação = gengiva uniformemente rosada.

1 - inflamação leve = modificação pequena na cor e textura gengivais.

2 - inflamação moderada = gengiva moderadamente avermelhada, vítrea, edemaciada e hipertrófica, com sangramento sob estímulo.

3 - inflamação severa = gengiva nitidamente avermelhada, hipertrófica, com tendência ao sangramento espontâneo e presença de ulceração.

(4) Índice de sangramento gengival (AINAMO; BAY ${ }^{3}$, 1975) para avaliação percentual dos sítios que sangram e não sangram à leve sondagem. Cada dente examinado é dividido em 4 faces - vestibular, lingual, mesial e distal - e registra-se a presença ou ausência de sangramento à sondagem. Somam-se os sítios com presença de sangramento e divide-se pelo número de dentes examinados. Após multiplicar o valor obtido por 100, obtém-se o percentual de pontos sangrantes por indivíduo. Nesse estudo, todos os dentes permanentes presentes foram examinados, considerando até os $2^{\text {os }}$. molares.

(5) Índice de placa ortodôntico (HEINTZE $\left.{ }^{87}, 1998\right)$ para determinar a quantidade de placa sobre o dente.

As regiões observadas para calcular este índice são: cervical, mesial/distal (que corresponde à região central do dente) e oclusal (que corresponde à região do terço incisal). Anota-se a presença ou ausência de placa em cada dente, considerando a face vestibular que é subdividida em 3 regiões, após aplicação de um agente evidenciador de placa. Neste estudo utilizou-se fucsina a $2 \%$. 
Somam-se os sítios com presença de placa, de acordo com cada região (cervical, central e oclusal). Após isto, multiplica-se o valor obtido da região cervical por 2, o valor da central por 3 e o da oclusal por 1. O Índice de placa ortodôntico é a soma dos resultados das multiplicações realizadas, dividido pelo número de dentes presentes $x$ $6 \times 100^{-1}$. Valores do Índice variando de $0-25$ representam uma boa higiene bucal; entre 26 - 50 pontos, higiene moderada; e acima de 50, pobre higiene bucal. Nessa pesquisa, todos os dentes permanentes presentes (até $2^{\text {os }}$. molares), exceto os dentes bandados, foram examinados.

\subsubsection{Análise estatística}

Todos os registros foram realizados em fichas individuais, desenvolvidas para este estudo (ANEXO 8). Os dados foram digitados em planilhas do Excel para os cálculos do índices. Para análise estatística foi utilizado o programa GraphPad InStat. As análises estatísticas foram feitas por Análise de Variância (teste de Tukey-Kramer) para os Índices Gengival, Placa e Sangramento e Kruskall-Wallis (Teste de Dunn) para os Índices de Manchas e Tártaro. O nível de significância adotado foi de 5\%. 
RESULTADOS 


\section{Resultados}

Do total de 85 pacientes que aceitaram participar da pesquisa, chegou-se ao final do experimento com 83 voluntários. Os dois voluntários desistentes chegaram a participar do exame baseline, entretanto, se ausentaram por vontade própria da pesquisa após este momento. Neste caso, optou-se por não incluir os respectivos exames na média final dos exames baseline. A composição dos grupos mantida do início ao final do experimento pode ser observada no ANEXO 4.

A análise do Índice de manchas nos diferentes períodos de exames pode ser observada na Tabela 1 e FIGURA 1, através da apresentação das médias de cada grupo. Na Tabela 2, numa visão mais detalhada, vê-se a distribuição clínica do manchamento nas superfícies linguais e vestibulares, com maior prevalência do manchamento na região lingual.

No grupo controle não houve diferenças estatisticamente significantes ao se comparar os resultados dos exames baseline com os exames de $6 \mathrm{e}$ 12 semanas $(p>0,05)$. Entretanto, tanto para o grupo B quanto para o grupo $C$, através da análise estatística foi possível verificar diferenças estatisticamente significantes nas comparações dos exames baseline com os de 6 semanas $(p<0,01)$ e dos exames baseline com os de 12 semanas $(p<0,001)$, enquanto que, entre os exames de 6 e 12 semanas, não houve diferença estatisticamente significante $(p>0,05)$.

Ainda considerando o Índice de manchas, no início do experimento os grupos A, B e C não apresentavam diferenças estatisticamente significantes entre si $(p>0,05)$. Nos exames após 6 semanas observou-se que os grupos $A \times B(p<0,01)$ e A x C $(p<0,01)$ apresentaram diferenças estatisticamente significantes entre $s i$, ao contrário dos grupos $B \times C(p>0,05)$. Nos exames de 12 semanas estas mesmas relações estatísticas forma mantidas.

Nas Tabelas 10, 11 e 12 podem ser observadas as porcentagens de aumento clínico do Índice de Manchas de acordo com o grupo (A, B e C) e com o exame realizado. 
TABELA 1 - Médias (dp) do Índice de Manchas (IM) dos grupos A, B e C, nos tempos: baseline, 6 e 12 semanas de utilização dos dentifrícios.

\begin{tabular}{cccc}
\hline & IM - baseline & IM - 6 semanas & IM - 12 semanas \\
\hline A & $0,37(1,57)^{\mathrm{a}, \mathrm{A}}$ & $1,41(4,37)^{\mathrm{a}, \mathrm{A}}$ & $9,22(27,59)^{\mathrm{a}, \mathrm{A}}$ \\
B & $3,25(7,68)^{\mathrm{a}, \mathrm{A}}$ & $33,71(54,39)^{\mathrm{b}, \mathrm{B}}$ & $46,78(54,05)^{\mathrm{b}, \mathrm{B}}$ \\
C & $1,18(4,33)^{\mathrm{a}, \mathrm{A}}$ & $39,29(59,18)^{\mathrm{b}, \mathrm{B}}$ & $49,25(69,22)^{\mathrm{b}, \mathrm{B}}$ \\
\hline
\end{tabular}

- As letras minúsculas diferentes indicam diferenças estatisticamente significantes intragrupos.

- As letras maiúsculas diferentes indicam diferenças estatisticamente significantes intergrupos.

TABELA 2 - Análise clínica da distribuição do Índice de Manchas (IM) de acordo com as superfícies vestibulares e linguais, nos grupos A, B e C, considerando os exames baseline e após 6 e 12 semanas de utilização dos dentifrícios.

\begin{tabular}{ccccccc}
\hline & \multicolumn{2}{c}{ IM - baseline } & \multicolumn{2}{c}{ IM - 6 semanas } & \multicolumn{2}{c}{ IM - 12 semanas } \\
\cline { 2 - 7 } & $\mathbf{V}$ & $\mathbf{L}$ & $\mathbf{V}$ & $\mathbf{L}$ & $\mathbf{V}$ & $\mathbf{L}$ \\
$\mathbf{A}$ & 0,07 & 0,30 & 0,00 & 1,41 & 0,00 & 9,22 \\
$\mathbf{B}$ & 1,82 & 1,43 & 8,36 & 25,36 & 14,29 & 32,50 \\
$\mathbf{C}$ & 0,57 & 0,61 & 4,36 & 34,93 & 13,25 & 36,00 \\
\hline
\end{tabular}

A Tabela 3 e a FIGURA 2 mostram as médias encontradas para 0 Índice de Tártaro $_{2}$ conforme o grupo e os exames realizados. Nos exames baseline os grupos A, B e C não apresentaram diferenças estatisticamente significantes entre si $(p>0,05)$. Quando da realização dos exames subseqüentes, observou-se que após 6 semanas de tratamento, o grupo A apresentou uma redução do Índice de Tártaro significante $(p<0,05)$, diferentemente dos grupos B e C ( $>0,05)$. Decorridas as 12 semanas, nos três grupos não foi verificada nenhuma diferença estatisticamente significante $(p>0,05)$ tanto considerando as comparações intra como intergrupos. 
As observações clínicas percentuais sobre o Índice de Tártaro nos grupos A, B e C podem ser verificadas nas Tabelas 10, 11 e 12.

TABELA 3 - Médias (dp) do Índice de Tártaro (IT) dos grupos A, B e C, nos tempos: baseline, 6 e 12 semanas de utilização dos dentifrícios.

\begin{tabular}{cccc}
\hline & IT - baseline & IT - 6 semanas & IT - 12 semanas \\
\hline A & $0,05(0,11)^{\mathrm{a}, \mathrm{A}}$ & $0,02(0,07)^{\mathrm{b}, \mathrm{B}}$ & $0,04(0,11)^{\mathrm{b}, \mathrm{A}}$ \\
B & $0,09(0,18)^{\mathrm{a}, \mathrm{A}}$ & $0,11(0,21)^{\mathrm{a}, \mathrm{A}}$ & $0,12(0,24)^{\mathrm{a}, \mathrm{A}}$ \\
C & $0,08(0,17)^{\mathrm{a}, \mathrm{A}}$ & $0,08(0,12)^{\mathrm{a}, \mathrm{A}}$ & $0,07(0,08)^{\mathrm{a}, \mathrm{A}}$
\end{tabular}

- As letras minúsculas diferentes indicam diferenças estatisticamente significantes intragrupos.

- As letras maiúsculas diferentes indicam diferenças estatisticamente significantes intergrupos.

As médias do Índice Gengival dos grupos A, B e C referentes aos exames baseline e após 6 e 12 semanas podem ser visualizadas na Tabela 4 e na FIGURA 3. No baseline não houve diferenças estatisticamente significantes entre os três grupos $(p>0,05)$. Observou-se que após 6 semanas de utilização dos dentifrícios propostos os três grupos apresentaram reduções estatisticamente significantes $(p<0,001)$, condições que foram mantidas até a realização do exame de 12 semanas $(p>0,05)$, considerando as comparações de cada grupo com ele mesmo.

Após as 6 semanas, os grupos B e C não apresentaram diferenças estatisticamente significantes entre si, diferentemente de quando comparados com o Grupo A. Quando considera-se o último exame (12 semanas), a análise de variância revelou que os grupos B e C não diferiram estatisticamente entre si ( $p>0,05)$, entretanto, as comparações: Grupo A x Grupo B e Grupo A x Grupo C apresentaram valores de p<0,01 e <0,001, respectivamente, resultando em diferenças significativas, sendo que os melhores resultados foram dos grupos $\mathrm{B}$ e C.

As observações clínicas percentuais sobre o Índice Gengival nos grupos A, B e C podem ser verificadas nas Tabelas 10, 11 e 12, de acordo com os diferentes tempos de exames. 
A Tabela 5 mostra a composição do Índice Gengival de acordo com os escores (0, 1, 2 e 3). Observa-se nessa análise clínica que em todos os grupos houve um grande aumento dos escores 0 (zero) e conseqüente diminuição dos escores 2 (dois) e 3 (três) considerando os exames após 6 semanas de utilização dos dentifrícios.

TABELA 4 - Médias (dp) do Índice Gengival (IG) dos grupos A, B e C, nos tempos: baseline, 6 e 12 semanas de utilização dos dentifrícios.

\section{IG - baseline IG - 6 semanas IG - 12 semanas}

$\begin{array}{llll}\text { A } & 1,21(0,31)^{\mathrm{a}, \mathrm{A}} & 0,79(0,25)^{\mathrm{b}, \mathrm{B}} & 0,71(0,28)^{\mathrm{b}, \mathrm{B}} \\ \text { B } & 1,17(0,29)^{\mathrm{a}, \mathrm{A}} & 0,53(0,20)^{\mathrm{c}, \mathrm{C}} & 0,50(0,20)^{\mathrm{c}, \mathrm{C}} \\ \text { C } & 1,21(0,30)^{\mathrm{a}, \mathrm{A}} & 0,56(0,26)^{\mathrm{c}, \mathrm{C}} & 0,46(0,21)^{\mathrm{c}, \mathrm{C}}\end{array}$

- As letras minúsculas diferentes indicam diferenças estatisticamente significantes intragrupos.

- As letras maiúsculas diferentes indicam diferenças estatisticamente significantes intergrupos.

TABELA 5 - Média (dp) dos scores 0, 1, 2 e 3 do Índice Gengival para os grupos A, B e C, conforme cada exame realizado.

\begin{tabular}{cllll}
\hline & Score 0 & Score 1 & Score 2 & Score 3 \\
\hline A - baseline & $14,33(19,56)$ & $58,11(13,19)$ & $34,59(17,42)$ & $0,22(1,15)$ \\
A - 6 sem. & $35,26(19,57)$ & $58,59(14,68)$ & $12,37(9,44)$ & $0,00(0,00)$ \\
A - 12 sem. & $42,19(21,88)$ & $52,52(15,12)$ & $11,52(9,99)$ & $0,00(0,00)$ \\
B - baseline & $14,79(14,84)$ & $55,43(16,26)$ & $32,07(16,82)$ & $0,14(0,45)$ \\
B - 6 sem. & $53,79(19,09)$ & $42,64(17,27)$ & $5,71(3,98)$ & $0,00(0,00)$ \\
B - 12 sem. & $57,82(20,87)$ & $38,54(17,22)$ & $5,79(3,96)$ & $0,00(0,00)$ \\
C - baseline & $13,29(14,57)$ & $56,00(18,67)$ & $34,82(20,49)$ & $0,18(0,94)$ \\
C - 6 sem. & $53,75(20,78)$ & $41,50(20,21)$ & $5,46(4,19)$ & $0,00(0,00)$ \\
C - 12 sem. & $59,75(18,47)$ & $35,64(16,28)$ & $5,32(4,15)$ & $0,00(0,00)$ \\
\hline
\end{tabular}


Em relação ao Índice de Sangramento, na Tabela 6 e na FIGURA 4 podem ser acessadas as médias de cada grupo nos tempos baseline, 6 e 12 semanas.

A Tabela 7 apresenta de forma decomposta o Índice de Sangramento para verificação da distribuição média da porcentagem de superfícies com sangramento positivo nas faces livres e proximais. Pode-se observar que clinicamente as superfícies livres apresentaram um número absoluto maior de sangramento positivo em comparação com as proximais, em todos os exames.

Nos exames baseline os grupos A, B e C não diferiram estatisticamente entre si $(p>0,05)$. Entretanto, após 6 semanas de experimento, as comparações Grupo A x Grupo B $(p<0,01)$ e Grupo A x Grupo C $(p<0,01)$ revelaram diferenças estatisticamente significantes, sendo que a comparação Grupo B x Grupo C $(p>0,05)$ não apresentou esta diferença. Estas condições foram mantidas até a realização do exame após 12 semanas. Nas comparações intragrupos, houve reduções estatisticamente significantes do exame baseline para o de 6 semanas $(p<0,001)$ nos três grupos. Do exame de 6 para 12 semanas não houve diferenças $(p>0,05)$ em nenhum grupo.

As reduções clínicas percentuais do Índice de Sangramento nos grupos A, B e C podem ser verificadas nas Tabelas 10, 11 e 12, de acordo com os diferentes tempos de exames. 
TABELA 6 - Médias (dp) do Índice de Sangramento (IS) dos grupos A, B e C, nos tempos: baseline, 6 e 12 semanas de utilização dos dentifrícios.

\begin{tabular}{cccc}
\hline & IS - baseline & IS - 6 semanas & IS - 12 semanas \\
\hline A & $33,33 \%(16,69)^{\mathrm{a}, \mathrm{A}}$ & $12,49 \%(8,60)^{\mathrm{b}, \mathrm{B}}$ & $12,39 \%(8,76)^{\mathrm{b}, \mathrm{B}}$ \\
B & $32,97 \%(16,19)^{\mathrm{a}, \mathrm{A}}$ & $6,95 \%(4,27)^{\mathrm{C}, \mathrm{C}}$ & $6,93 \%(4,87)^{\mathrm{c}, \mathrm{C}}$ \\
C & $33,66 \%(19,15)^{\mathrm{a}, \mathrm{A}}$ & $7,19 \%(5,51)^{\mathrm{c}, \mathrm{C}}$ & $6,71 \%(5,43)^{\mathrm{c}, \mathrm{C}}$ \\
\hline
\end{tabular}

- As letras minúsculas diferentes indicam diferenças estatisticamente significantes intragrupos.

- As letras maiúsculas diferentes indicam diferenças estatisticamente significantes intergrupos.

TABELA 7 - Evolução clínica da média do número de pontos sangrantes (dp), de acordo com os grupos A, B e C, considerando o exame realizado e a região do dente (superfícies livres e proximais).

\begin{tabular}{ccc}
\hline & N - livres & N - proximais \\
\hline A - baseline & $20,41(10,64)$ & $14,78(7,89)$ \\
A - 6 sem. & $9,30(6,89)$ & $4,00(3,72)$ \\
A - 12 sem. & $8,96(6,94)$ & $4,07(3,49)$ \\
B - baseline & $17,82(8,78)$ & $15,36(8,53)$ \\
B - 6 sem. & $4,54(3,24)$ & $2,86(2,38)$ \\
B - 12 sem. & $4,18(3,52)$ & $2,64(2,36)$ \\
C - baseline & $20,50(10,96)$ & $15,21(10,55)$ \\
C - 6 sem. & $5,00(3,70)$ & $2,07(1,78)$ \\
C - 12 sem. & $4,32(3,09)$ & $2,21(2,25)$ \\
\hline
\end{tabular}

As médias do Índice de Placa de cada grupo podem ser acessadas na Tabela 8 e na FIGURA 5, considerando-se os três exames.

Analisando clinicamente a distribuição média de superfícies (cervical, central e oclusal) com presença de placa, vê-se o Índice de Placa detalhado na Tabela 9. Mesmo com as devidas reduções observadas, há um maior 
número de presença de placa na superfície central dos dentes, em todos os exames.

As Tabelas 10, 11 e 12 apresentam as reduções percentuais do Índice de Placa comparando-se o período compreendido entre os exames baseline e 6 semanas, bem como o de 6 semanas até 12 semanas.

Observou-se que, inicialmente não houve diferenças estatisticamente significantes entre os Grupos A, B e C no baseline ( $p>0,05)$. Nos exames de 6 semanas, as comparações: Grupo A x Grupo B e Grupo A x Grupo C apresentaram diferenças significantes $(p<0,001)$, fato que não ocorreu na relação Grupo B x Grupo C ( $p>0,05)$. A análise de variância demonstrou reduções estatisticamente significantes no Índice de Placa do baseline para 6 semanas em todos os grupos e, do segundo para o terceiro exame nos grupos A e B. Apesar do grupo C não ter apresentado redução adicional no terceiro exame, não houve diferença estatisticamente significante nos índices de placa quando se comparam os três grupos após 12 semanas $(p>0,05)$.

TABELA 8 - Médias (dp) do Índice de Placa (IP) dos grupos A, B e C, nos tempos: baseline, 6 e 12 semanas de utilização dos dentifrícios.

\begin{tabular}{cccc}
\hline & IP - baseline & IP - 6 semanas & IP - 12 semanas \\
\hline A & $83(12,11)^{\mathrm{a}, \mathrm{A}}$ & $65(10,61)^{\mathrm{b}, \mathrm{B}}$ & $55(19,28)^{\mathrm{d}, \mathrm{D}}$ \\
B & $78(12,22)^{\mathrm{a}, \mathrm{A}}$ & $51(14,35)^{\mathrm{c}, \mathrm{C}}$ & $45(15,44)^{\mathrm{d}, \mathrm{D}}$ \\
C & $82(10,86)^{\mathrm{a}, \mathrm{A}}$ & $48(14,21)^{\mathrm{c}, \mathrm{C}}$ & $48(14,21)^{\mathrm{C}, \mathrm{D}}$
\end{tabular}

- As letras minúsculas diferentes indicam diferenças estatisticamente significantes intragrupos.

- As letras maiúsculas diferentes indicam diferenças estatisticamente significantes intergrupos. 
TABELA 9 - Evolução da média (dp) do número de pontos com presença de placa $(\mathrm{N})$ dos grupos $\mathrm{A}, \mathrm{B}$ e $\mathrm{C}$, de acordo com o exame realizado e a região do dente (cervical, central e oclusal).

\begin{tabular}{cccc}
\hline & N - cervical & N - central & N - oclusal \\
\hline A - baseline & $16,81(4,38)$ & $20,15(2,87)$ & $11,23(6,04)$ \\
A - 6 sem. & $9,73(3,56)$ & $18,85(3,31)$ & $4,92(4,49)$ \\
A - 12 sem. & $8,54(4,38)$ & $15,81(5,33)$ & $4,04(3,87)$ \\
B - baseline & $15,54(5,85)$ & $20,39(3,19)$ & $8,64(4,60)$ \\
B - 6 sem. & $6,71(4,15)$ & $16,50(3,43)$ & $1,57(2,25)$ \\
B - 12 sem. & $5,36(3,49)$ & $13,57(3,90)$ & $1,29(2,12)$ \\
C - baseline & $17,36(4,52)$ & $20,46(3,13)$ & $11,39(6,29)$ \\
C - 6 sem. & $5,46(4,08)$ & $16,79(4,40)$ & $1,79(3,73)$ \\
C - 12 sem. & $5,46(4,08)$ & $16,79(4,40)$ & $1,79(3,73)$ \\
\hline
\end{tabular}

TABELA 10 - Porcentagens de redução/aumento das médias de cada índice do grupo $A$, considerando o baseline em relação ao exame após 6 semanas e o exame de 6 semanas em relação ao de 12 semanas.

\begin{tabular}{ccc}
\hline & $\mathbf{6}$ semanas & 12 semanas \\
\hline Índice de Manchas & $+281,08$ & $+533,90$ \\
Índice de Tártaro & $-60,00$ & $+100,00$ \\
Índice Gengival & $-34,71$ & $-10,00$ \\
Índice de Sangramento & $-62,53$ & $-1,00$ \\
Índice de Placa & $-21,69$ & $-15,00$ \\
\hline
\end{tabular}


TABELA 11 - Porcentagens de redução/aumento das médias de cada índice do grupo $B$, considerando o baseline em relação ao exame após 6 semanas e o exame de 6 semanas em relação ao de 12 semanas.

\begin{tabular}{ccc}
\hline & $\mathbf{6}$ semanas & $\mathbf{1 2}$ semanas \\
\hline Índice de Manchas & $+937,23$ & $+38,80$ \\
Índice de Tártaro & $+22,22$ & $+9,09$ \\
Índice Gengival & $-54,70$ & $-5,66$ \\
Índice de Sangramento & $-78,92$ & $-0,29$ \\
Índice de Placa & $-34,62$ & $-11,76$ \\
\hline
\end{tabular}

TABELA 12 - Porcentagens de redução/aumento das médias de cada índice do grupo C, considerando o baseline em relação ao exame após 6 semanas e o exame de 6 semanas em relação ao de 12 semanas.

\begin{tabular}{ccc}
\hline & $\mathbf{6}$ semanas & $\mathbf{1 2}$ semanas \\
\hline Índice de Manchas & $+3229,66$ & $+25,35$ \\
Índice de Tártaro & 0,00 & $-12,50$ \\
Índice Gengival & $-53,72$ & $-17,86$ \\
Índice de Sangramento & $-78,64$ & $-6,68$ \\
Índice de Placa & $-41,46$ & 0,00 \\
\hline
\end{tabular}


FIGURA 1 - Médias do Índice de manchas nos exames baseline e após 6 e 12 semanas de tratamento com os dentifrícios propostos para os grupos $A$, B e C.

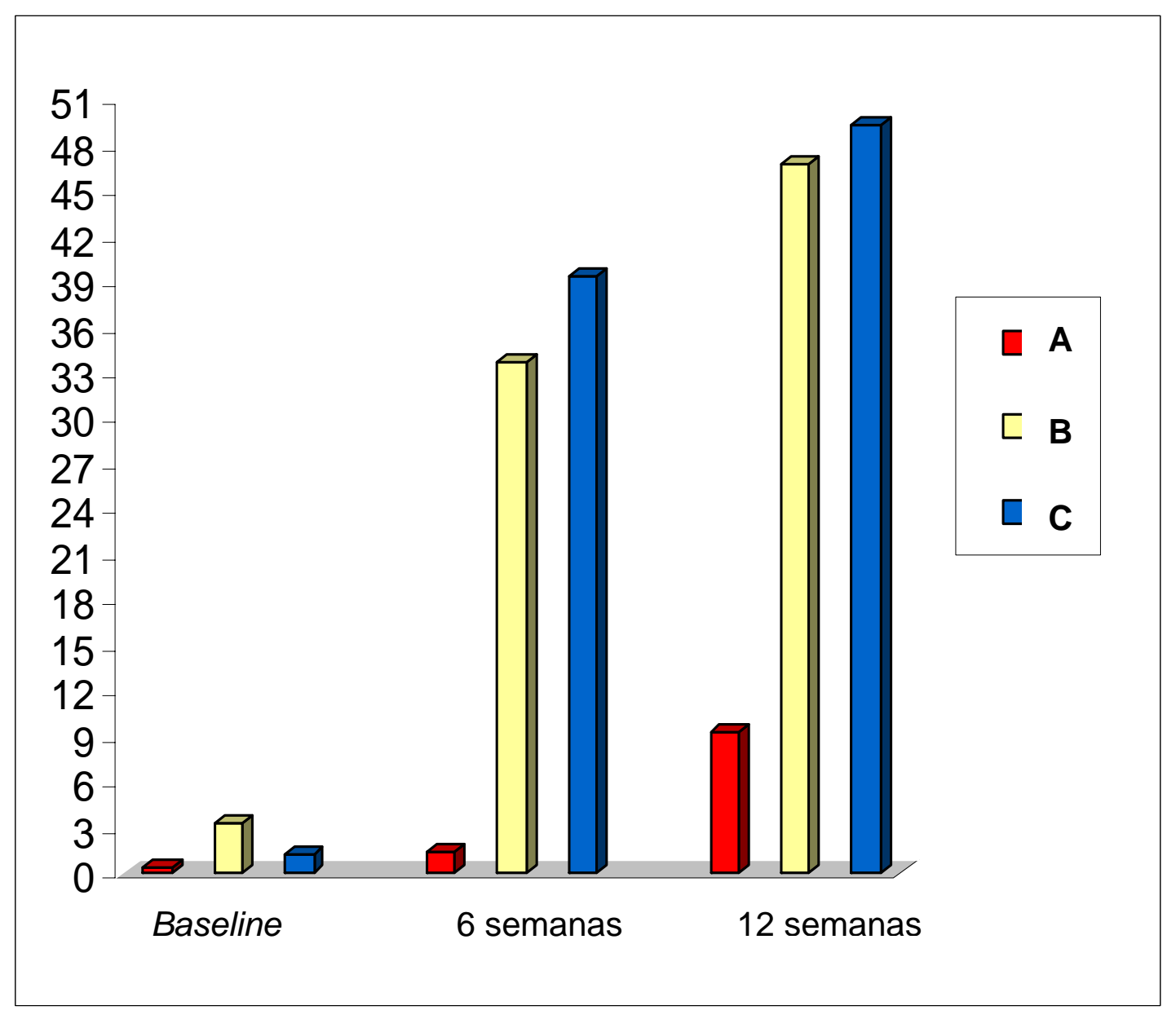


FIGURA 2. Médias do índice de tártaro nos exames baseline e após 6 e 12 semanas de tratamento com os dentifrícios propostos para os grupos A, B e C.

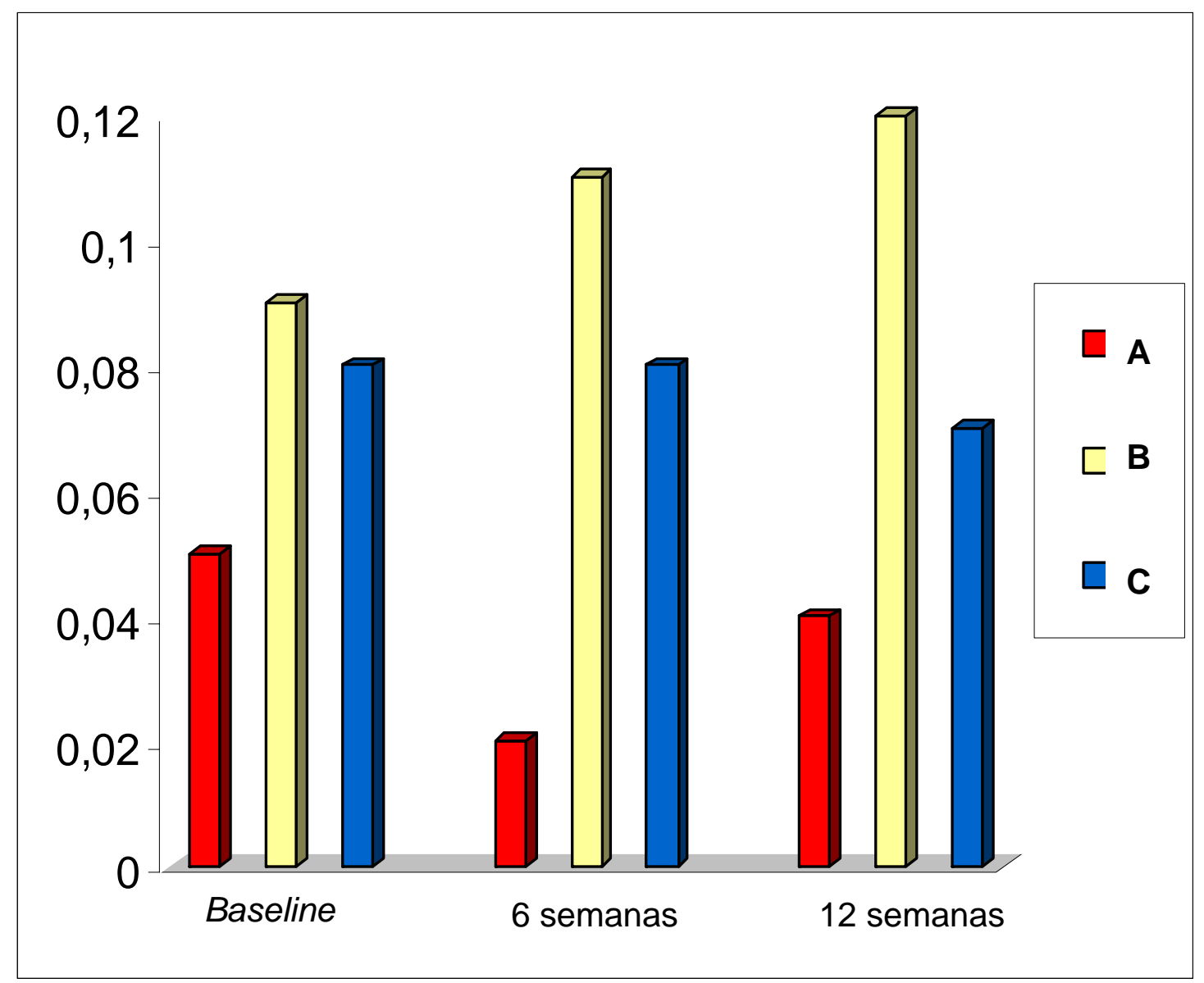


FIGURA 3. Médias do índice gengival nos exames baseline e após 6 e 12 semanas de tratamento com os dentifrícios propostos para os grupos A, B e C.

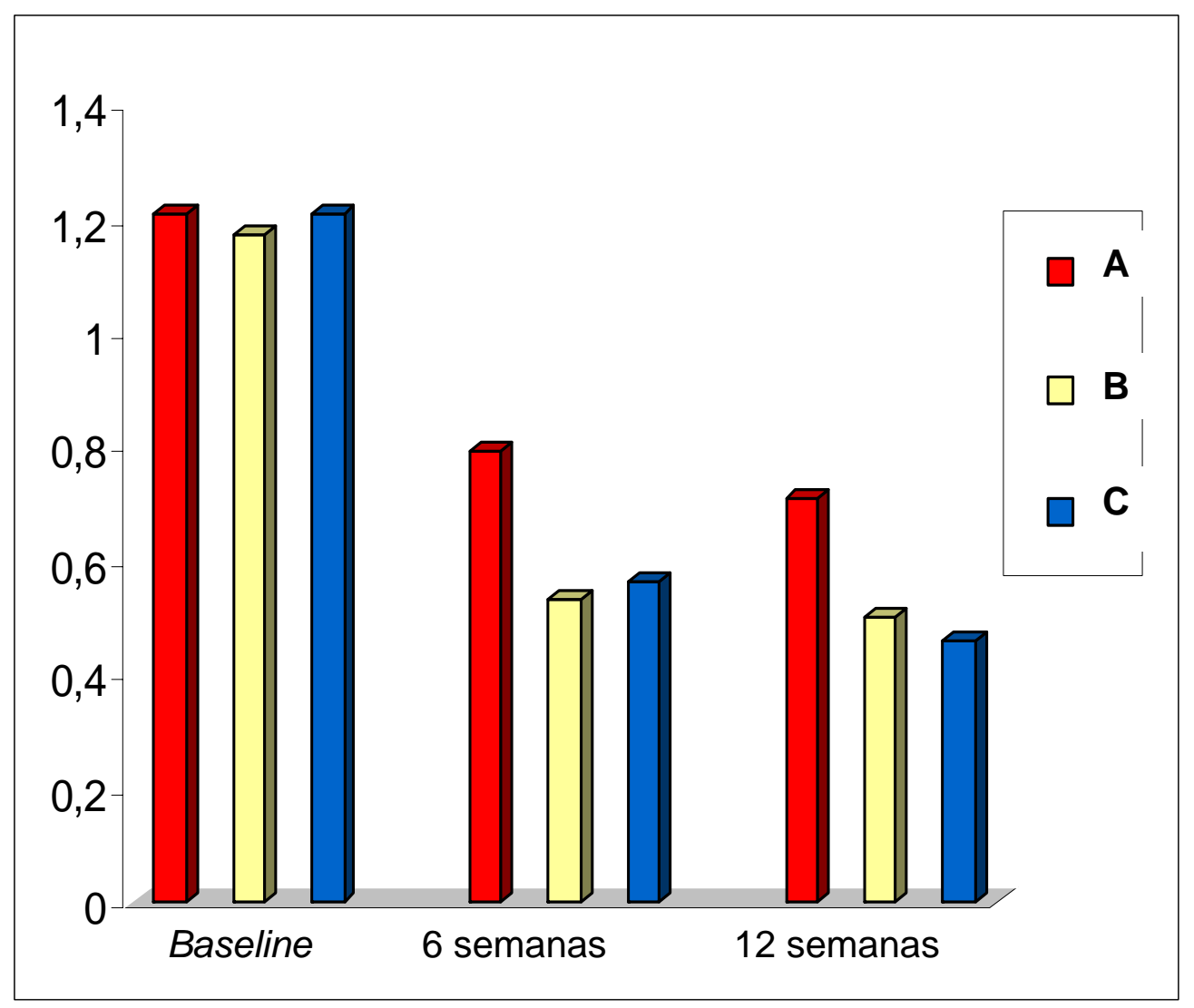


FIGURA 4. Médias do índice de sangramento gengival nos exames baseline e após 6 e 12 semanas de tratamento com os dentifrícios propostos para os grupos A, B e C.

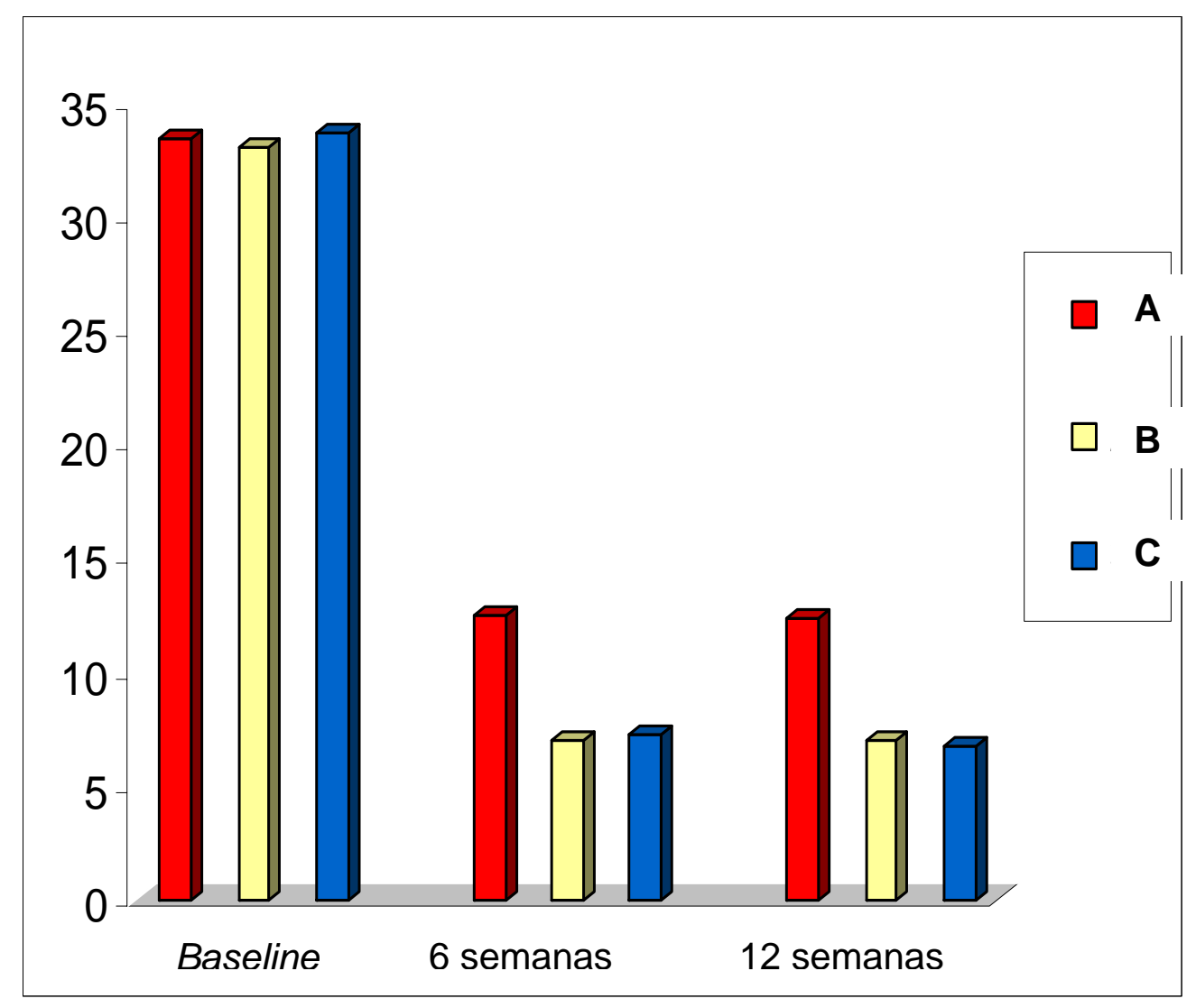


FIGURA 5. Médias do índice de placa dentária nos exames baseline e após 6 e 12 semanas de tratamento com os dentifrícios propostos para os grupos A, B e C.

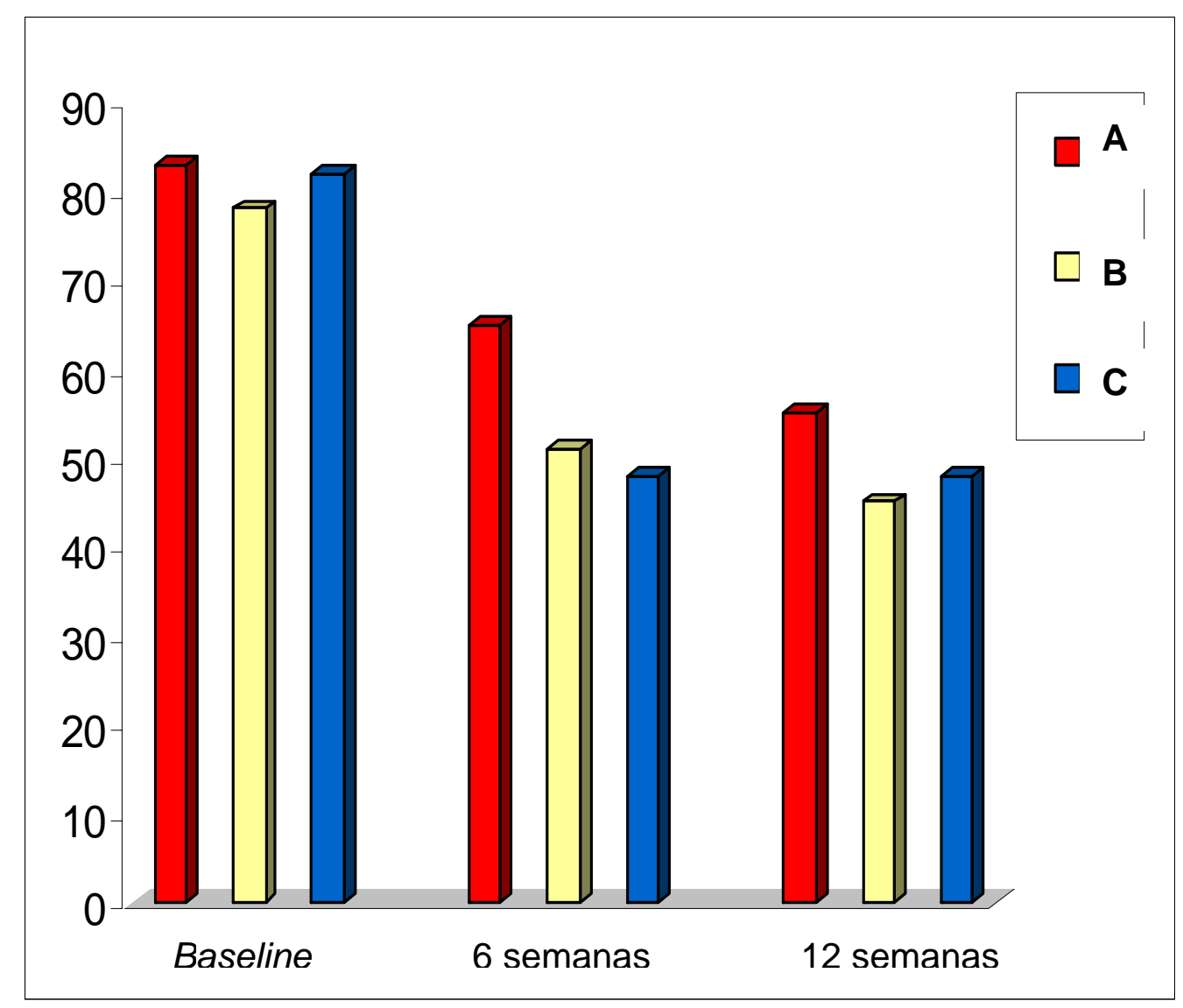


DISCUSSÃO 


\section{DISCUSSÃO}

A cada dia, o arsenal de métodos e substâncias químicas capazes de melhorar as condições de higiene bucal tem evoluído. O cirurgião-dentista tem à sua disposição várias alternativas para que seus pacientes sejam instruídos e, quando necessário, "medicados" para que suas condições de saúde bucal sejam satisfatórias.

Conseguir manter um correto controle da placa dentária e um periodonto saudável com ausência de inflamação e sangramento, não deixa de ser um grande desafio, tanto para o dentista que necessita avaliar, orientar e tratar seus pacientes, como para os pacientes, os quais têm grande parcela de responsabilidade na manutenção de sua saúde $\left(\right.$ AXELSSON $^{8}, 1993$; SREENIVASAN et al. ${ }^{158}, 2003$; SEKINO, et al. ${ }^{149}$, 2003). Em se tratando de pacientes ortodônticos, esse desafio é ainda maior. No tratamento ortodôntico fixo, há um aumento das superfícies de retenção da placa dentária e, devido a isso, a grande maioria dos pacientes acaba apresentando dificuldades de higienização, ocasionando valores elevados do índices de placa (UETANABARO; MARTINS; ANDRADE ${ }^{163}$, 1984; HEINTZE ${ }^{86}$, 1996).

O acúmulo de placa dentária é um pré-requisito para o desenvolvimento de gengivite que, por sua vez, pode evoluir para a periodontite em indivíduos susceptíveis (SEKINO et al. ${ }^{149}, 2003$ ). Tanto a gengivite como a periodontite são associadas à presença de placa e, sua remoção acaba por inibir a ocorrência e progressão dessas doenças (IACONO et al. ${ }^{90}$, 1998).

O método mais comum para o controle de placa dentária supragengival é a remoção mecânica feita principalmente através da escova dentária e, adicionalmente, ao uso do fio dental (LÖE ${ }^{105}$, 1973; TORRES ${ }^{162}$, 2000; SANTOS ${ }^{139}$, 2003). Entretanto, devido às dificuldades em se conseguir uma eficiente cooperação dos pacientes, por razões das mais diversas, um grande número de agentes quimioterápicos utilizados em soluções para bochechos e em dentifrícios tem sido analisado quanto à sua 
segurança e eficácia no controle de placa (IACONO et al. ${ }^{90}, 1998$; CURY $^{47}$, 1999).

Vários têm sido os critérios estabelecidos para que um quimioterápico possa ser indicado para o uso clínico, tais como: ausência de toxicidade, não ser alergênico, ser seguro, ter comprovação clínica de reduções significantes de placa e gengivite, ter substantividade, ser seletivo e ter especificidade para agir na microbiota patogência, apresentar sabor agradável, ter custo acessível e ser de fácil utilização (VAN DER OUDERAA ${ }^{164}$, 1991; van RIJKOM; TRUIN; van't HOF ${ }^{166}$, 1996; IACONO et al. ${ }^{90}$, 1998). Quanto mais próximo dessas características um agente químico se encontre, melhor ele será (VAN DER OUDERAA $\left.{ }^{164}, 1991\right)$.

A clorexidina é a substância química considerada o "padrão ouro" em comparação aos demais produtos desenvolvidos para agir sobre a formação de placa e desenvolvimento da gengivite (GREENSTEIN; BERMANT; JAFFIN $^{79}$, 1986; ELWORTHY et al. ${ }^{59}$, 1996; VINHOLIS et al. ${ }^{168}$, 1996; JONES $^{97}$, 1997; OWENS et al. ${ }^{126}$, 1997; BOWEN ${ }^{33}$, 1999). Em ortodontia, vários estudos comprovaram os efeitos positivos do uso da clorexidina administrada através de soluções para bochechos, géis e vernizes (FEIST; MICHELI; SARIAN ${ }^{61}$, 1989; BRIGHTMAN et al. ${ }^{35}$, 1991; STEFANI; LIMA ${ }^{160}$, 1996; HEITZE ${ }^{86}$, 1996; JÚNIOR et al. $^{99}$, 1996; GARIB et al. ${ }^{67}$, 1997; ANDERSON et al. $\left.{ }^{6}, 1997\right)$.

O fato de pacientes ortodônticos apresentarem um risco maior para o acúmulo de placa e, conseqüentemente, maior risco para o desenvolvimento de gengivite e cárie dentária, não torna impraticável o acesso à condições satisfatórias de saúde bucal, mesmo exigindo maior atenção e cuidados tanto do ortodontista como do paciente (FELIU ${ }^{62}$, 1982; UETANABARO; MARTINS; ANDRADE ${ }^{163}$, 1984; HEINTZE $^{86}, 1996$; DERKS et al. $\left.{ }^{53}, 2004\right)$. As freqüentes visitas para manutenção ortodôntica são oportunidades para que o cirurgião-dentista ensine as técnicas para promover a boa higiene bucal, além de reforçar as instruções oferecidas para que hábitos saudáveis sejam estimulados(FELIU $\left.{ }^{62}, 1982\right)$. O ortodontista deve estar atento aos problemas 
de higiene bucal de seus pacientes, pois um dos principais objetivos da Ortodontia é conseguir uma boa harmonia dental e esquelética, preservando a higidez dos dentes e superfícies de suporte. Para se promover e manter uma saúde bucal satisfatória, os pacientes ortodônticos podem ser submetidos a um programa rigoroso de higienização bucal e controle de placa dentária antes e durante a terapia ortodôntica (UETANABARO; MARTINS; ANDRADE ${ }^{163}, 1984$; BASTOS; HENRIQUES; OLYMPIO ${ }^{26}$, 2001).

Considerando os agentes antimicrobianos e antiplaca como adjuntos na busca de uma higiene bucal satisfatória e os pacientes ortodônticos com vários fatores indicativos de alto risco à cárie e gengivite, o presente trabalho teve como objetivos avaliar quais seriam os efeitos da clorexidina administrada através de dentifrícios, na melhora da saúde bucal considerando os índices de Placa, Gengival e Sangramento. Adicionalmente, pretendeu-se observar qual o efeito do produto sobre o manchamento extrínseco do esmalte dentário e sobre o formação de cálculo dentário.

Na literatura científica não são muitos os estudos sobre dentifrícios com clorexidina em suas formulações, especialmente pelo fato de que, quando administrada nos dentifrícios convencionais, a clorexidina pode interagir com alguns sulfactantes, detergentes e abrasivos contidos nos mesmos, sendo inativada (BARKVOLL; ROLLA; SVENDEN ${ }^{16}, 1989$; VAN GRUNSVEN; CARDOSO ${ }^{165}$, 1995). Discute-se também sua efetividade em formulações de dentifrícios, levando em conta a relação custo-benefício de tal aplicação, principalmente devido ao efeito colateral provocado pela clorexidina: o manchamento extrínseco (GARIB et al. ${ }^{67}$, 1997; GUGUSHE; WET; ROJAS-SILVA ${ }^{83}$, 1994; TORRES ${ }^{162}$, 2000). A introdução da clorexidina aos dentifrícios é vista como uma maneira prática de utilização do produto, pois não interfere na rotina de higienização do paciente (MURRAY; RUGG-GUNN ${ }^{120}$, 1982; YATES et al. ${ }^{169}$, 1993). Nos momentos de escovação dentária, o medicamento é então aplicado.

O presente estudo contou com a participação de 83 voluntários, todos pacientes com aparelhos ortodônticos fixos. Durante a pesquisa, 5 pacientes apresentaram algum problema de saúde e necessitaram fazer uso de 
antibióticos (1 voluntário do grupo A, 2 do Grupo B e 2 do grupo C). Quando da exclusão dos valores dos índices desses pacientes, não houve alteração estatisticamente significante dos resultados calculados. Portanto, optou-se por mantê-los na pesquisa.

Mesmo não sendo o objetivo do presente trabalho, para uma melhor caracterização dos grupos, um questionário inicial foi respondido pelos participantes. Nesse questionário sobre os hábitos dos participantes da pesquisa, viu-se que, nos respectivos grupos A, B e C, a escovação realizada 3 vezes ao dia era de: $44,44 \%, 42,86 \%$ e $37,04 \%$, enquanto que, o uso de escovas interdentais e unitufo, era de $11,11 \%, 3,57 \%$ e $22,22 \%$. Entretanto, após o início da pesquisa, a freqüência e o tempo de escovação foram padronizados para se evitar viesses. No que se refere à utilização de escovas unitufos e interdentais, não houve solicitação para que os participantes fizessem ou não uso das mesmas. Cada paciente, sendo controle dele mesmo, poderia continuar a utilizá-las caso já as tivesse. Todo tipo de bochecho com substâncias químicas foi suspenso ao iniciar a pesquisa. A porcentagem média de utilização habitual destes produtos, anteriormente à pesquisa, variava de 25 a 40\% nos 3 grupos.

Instituiu-se padronizar a escovação em 3 vezes ao dia pois, além de ser uma recomendação do fabricante ao formular os dentifrícios com clorexidina, trata-se de uma prática mais usual de hábitos de higiene. O fato dos pacientes serem portadores de aparelhos fixos, também fez com que se recomendasse 2 minutos de escovação, pois a higiene nesses casos exige mais tempo do que aqueles usualmente padronizados em pesquisas semelhantes a essa, isto é, em média 1 minuto de escovação (YATES, et al. ${ }^{169}, 1993$; JENKINS; ADDY; NEWCOMBE $\left.{ }^{94}, 1993\right)$.

Através dos questionários de acompanhamento e do consumo médio de dentifrícios, pode-se dizer que o grau de colaboração dos pacientes foi satisfatório nos três grupos. As respostas aos questionários revelaram que a manutenção da freqüência de escovação padronizada foi confirmada, em média, por $66,45 \%$ dos participantes no exame de 6 semanas e por $70,88 \%$ após 12 semanas. Somente 10 participantes relataram manter a freqüência 
de 2 vezes ao dia ( 5 deles no exame de 6 semanas e 5 no de 12 semanas), e os demais escovavam de 3 a 4 vezes ou mais. Poucos foram os relatos de dificuldades no cumprimento do protocolo proposto. A falta de tempo ou mesmo "preguiça" em usar o fio dental foi a dificuldade mais relatada pelos participantes (média de 10,87\% das respostas).

Os grupos A, B e C, respectivamente, responderam que receberam instruções de seu ortodontista após a colocação do aparelho $(88,89 \%$, $89,29 \%$ e $85,19 \%$ ), prevalecendo a orientação para que a escovação fosse realizada 3 vezes ao dia juntamente com o uso do fio dental $(66,67 \%$, $71,43 \%$ e $74,07 \%)$. As demais instruções fizeram referência à não ingestão de alimentos duros e chicletes, à utilização de escovas interdentais e passafio, entre outras menos citadas. Em nenhum questionário foi citada algum tipo de escovação supervisionada. Esses dados chamaram a atenção pois, somente as orientações não foram suficientemente eficazes para garantir uma higiene satisfatória, afinal, nos exames baseline, as médias dos Índices de Placa e Gengival demonstraram higiene bucal deficiente em todos os grupos.

Os dentifrícios com clorexidina utilizados pelos pacientes ortodônticos conforme o protocolo já relatado promoveram reduções estatisticamente significantes dos Índices Gengival, Sangramento e de Placa, sugerindo-se então, a estabilização da clorexidina no veículo de administração proposto.

A introdução do NaF em associação com a clorexidina não interferiu negativamente nos resultados, pois foi possível observar a semelhança do desempenho dos dentifrícios B e C. Dessa forma, torna-se possível oferecer um efeito sinérgico de prevenção, aliando o $\mathrm{F}$ à clorexidina. Esses achados foram semelhantes ao estudo realizado por YATES et al. ${ }^{169}, 1993$.

Estudos envolvendo aplicações simultâneas de $\mathrm{F}$ e clorexidina têm mostrado resultados promissores em indivíduos de alto risco à cárie dentária e gengivite (DOLLES; GJERMO ${ }^{56}$, 1980; JENKINS; ADDY; NEWCOMBE ${ }^{94}$, 1993; DEL BEL CURY; REBELO; CURY ${ }^{48}$, 1994; van RIRIJKOM; TRUIN; van't HOF $\left.{ }^{166}, 1996\right)$. 
A ação antiplaca promovida pela clorexidina nos grupos B e C foi estatisticamente significante após 6 semanas de utilização do produto. Diferentemente dos outros índices avaliados, o Índice de Placa sofreu ainda uma redução adicional, entre o exame de 6 para 12 semanas, nos grupos $A$ e B. Pode-se especular que essa redução foi decorrente de um aumento da destreza manual na remoção da placa e um maior envolvimento dos voluntários com o estudo ("efeito Hawthorne" - JENKINS; ADDY; NEWCOMBE ${ }^{94}, 1993$; YATES et al. $\left.{ }^{169}, 1993\right)$.

Algumas observações devem ser feitas quando da aferição do Índice de Placa. A primeira delas diz respeito ao índice utilizado nessa pesquisa, o qual não possibilitou a verificação da maior ou menor quantidade de placa na região analisada. Dessa forma, o mesmo registro é feito para um pequeno acúmulo de placa quanto para um maior, contanto que exista placa presente na região observada. Outro fator é o de que, o registro retrata uma condição um tanto quanto "pontual" de higienização, diferentemente dos Índices Gengival e de Sangramento que acabam sendo um reflexo da higiene bucal com o passar do tempo.

Através dos resultados dos Índices Gengival e de Sangramento a melhora observada nos 3 grupos se deu após 6 semanas de estudo, mantendo-se até o final das 12 semanas, sendo que as maiores reduções foram verificadas nos grupos B e C. Essa melhora verificada em todos os grupos foi também percebida pelos pacientes. Segundo relatos nos questionários de acompanhamento, uma média de 29,47\% (em 6 semanas) e $27,83 \%$ (em 12 semanas) descreveram ter percebido melhora nas condições gengivais e diminuição do sangramento. O benefício máximo promovido pela clorexidina na redução de placa dentária e gengivite também foram verificadas após 45 dias de uso da substância nos estudos de YATES, et al. ${ }^{169}$, 1993; GUGUSHE; WET; ROJAS-SILVA ${ }^{83}, 1994$ e JÚNIOR, et al. ${ }^{99}$, 1996.

Os grupos B e C apresentaram reduções dos Índices de Placa e Gengivite, com porcentagens ao final do estudo de: $46,38 \%$ e 60,36 para o 
grupo B e 41,46\% e 71,58\% para o grupo C, respectivamente, somando as reduções de 6 e 12 semanas. IACONO et al. ${ }^{90}$, 1998 fizeram uma avaliação dos métodos de controle de placa e verificaram que, estudos com duração de 6 meses ou mais, demonstraram que a eficácia clínica da clorexidina na redução de placa dentária variou de 48 a 61\% enquanto que em relação à gengivite, este percentual foi de 27 a 67\% (LÖE; SCHIOTT ${ }^{107}$, 1970; LÖE et al. $^{106}$, 1976; GROSSMAN; REITER; STURZENBERGER ${ }^{81}$, 1986). No caso do produto Listerine, estas reduções variaram de 19\% a 35\% para o índice de placa e de $17 \%$ a $37 \%$ para gengivite. Apesar de não apresentar como efeito colateral o manchamento, na utilização de Listerine houve a verificação de sensação de queimação na mucosa bucal quando do início da aplicação (LAMSTER et al. ${ }^{100}$, 1983; GORDON; LAMSTER; SEIGER ${ }^{77}$, 1985; SCHEIE ${ }^{143}$, 1989; CIANCIO $^{45}$, 1995; IACONO et al. $\left.{ }^{90}, 1998\right)$. Clinicamente, quando há a associação de Triclosan com citrato de zinco, observam-se reduções de 0 a 30\% no Índice de Placa e de 20 a 75\% no Índice Gengival (IACONO, et al. ${ }^{90}$, 1998).

Apesar da verificação da ação química dos dentifrícios experimentais propostos, mais do que uma nova forma de se utilizar a clorexidina na prevenção de doenças como cárie e gengivite, esta pesquisa suscitou a importância da orientação sobre os cuidados com a saúde bucal no período de tratamento ortodôntico. Somente a instrução e motivação que foi oferecida a todos os participantes dessa pesquisa, já surtiu um efeito clínico e estatístico de melhora, mesmo que, nos grupos B e C este quadro tenha sido superior, comprovando a eficácia química da clorexidina. Os pacientes examinados necessitam de maior atenção visto que as médias do Índice Gengival retrataram gengivite moderada no início da pesquisa, nos três grupos de estudo. O reforço educacional nesses casos deve ser constante, mesmo que se prescreva substâncias químicas como adjuntas à higienização (HEINTZE ${ }^{86}$, 1996; SOUZA; FALCÃO; ARAÚJO ${ }^{157}$, 1999).

SEKINO et al. ${ }^{149}$, 2003 observaram em suas investigações que quanto maior o número de bactérias presentes na saliva, maior e mais rápida pode ser a formação de placa. Entretanto, esse não é o único fator responsável 
pelo acúmulo de placa e aparecimento de gengivite. O uso de clorexidina faz com que haja uma efetiva redução dos microrganismos na saliva (JONES ${ }^{97}$, 1997; SREENIVASAN et al. ${ }^{158}$, 2003).

Um número absoluto maior de superfícies sangrantes foi verificado nas faces livres, diferentemente de alguns artigos (HEINTZE ${ }^{86}$, 1996; HEINTZE et al. $^{87}$, 1998) mas, desde o início da pesquisa, este padrão foi mantido. Pode-se considerar que, mesmo que clinicamente tenha existido um maior número de pontos sangrantes nas faces livres, isto não isenta as superfícies proximais de apresentarem algum grau de gengivite. Além do que, muitos pacientes apresentavam hiperplasias interproximais generalizadas, sem que estas sangrassem à sondagem. Isso porque, do ponto de vista clínico, a inflamação gengival pode gerar dois tipos de resposta do tecido: edematosa e fibrótica. A resposta edematosa do tecido é caraterizada por uma gengiva lisa, brilhante, macia e vermelha. Na resposta fibrótica, apesar da gengiva se apresentar mais firme, pontilhada e opaca do que a edematosa, ela é mais grossa que o normal e com alterações em sua margem (CARRANZA, NEWMAN $\left.{ }^{39}, 1996\right)$.

A controle de placa, gengivite e sangramento deve ser freqüente e eficiente nos pacientes ortodônticos. GLANS; LARSSON; OGAARD ${ }^{76}, 2003$ verificaram que após a instalação de aparelhos ortodônticos, todos os pacientes apresentaram gengivite leve, mas após a retirada dos aparatos ortodônticos, as condições gengivais voltaram ao normal. Esse fato não justifica a negligência com a higienização durante o tratamento pois, se durante o tratamento as condições gengivais forem insatisfatórias as forças ortodônticas que serão realizadas poderão ocasionar maiores problemas periodontais pois a movimentação estará sendo feita na presença de inflamação.

LUCAS; LUCAS ${ }^{110}$, 1997 citaram que, na presença de inflamação gengival, as forças produzidas pelos aparatos ortodônticos atuam agravando a resposta dos tecidos, produzindo, conseqüentemente, um aumento na destruição dos tecidos de proteção e sustentação dos dentes. HEINTZE ${ }^{86}$, 1996, também relata esses fatos, afirmando que, principalmente em 
adolescentes, são as hiperplasias que na maioria das vezes constituem uma reação ao acúmulo de placa. Ao mesmo tempo, elas dificultam a higienização, formando um ciclo vicioso.

Em certos casos, hiperplasia moderada pode ocorrer durante o tratamento ortodôntico, mesmo com a manutenção de uma correta higiene bucal (ZACHRISSON $\left.{ }^{172}, 1974\right)$.

Em relação aos efeitos colaterais provocados pela clorexidina, nesse estudo, o manchamento extrínseco do esmalte dentário foi verificado, mesmo que, muitas vezes esteticamente despercebido segundo os relatos dos questionários de acompanhamento. Essa percepção por parte dos pacientes faz com que o uso da clorexidina em dentifrícios seja esteticamente aceitável (RUSSEL; BAY ${ }^{136}, 1978$; SANZ et al. ${ }^{140}, 1994$ ), mesmo que estatisticamente os dados não demonstrem este fato. $O$ manchamento acaba por ser compensado pelos benefícios provenientes do uso dos dentifrícios com clorexidina, tanto em relação à placa dentária quantos aos Índices Gengival e de Sangramento.

Mesmo que sem diferenças estatísticas encontradas, o fato do valor do Índice de Manchas ser maior clinicamente no grupo C, vem ao encontro do estudo de DOLLES; ERIKSEN; GJERMO ${ }^{55}, 1979$, os quais citam que, com o flúor, o manchamento pode ser retardado mas não evitado. A questão da dieta e da habilidade na escovação dentária também merecem ser destacadas pois estas podem interferir no maior ou menor Índice de Mancas individual (ALSTAD; ZACHRISSON ${ }^{5}$, 1979; ELLINGSEN; ROLLA; ERIKSEN $^{58}$, 1982; ADDY; MORRAN $\left.{ }^{2}, 1985\right)$. O consumo de produtos cromógenos foi praticamente semelhante entre os grupos e foi relatado como sendo mais que 3 vezes por semana nas proporções de $44,44 \%$ (grupo A), 53,57\% (grupo B) e 51,85\% (grupo C).

Não houve nenhum relato de descamação da mucosa ou interferência permanente no paladar. Houve sim, nas respostas aos questionários, vários relatos sobre o gosto um tanto quanto amargo do dentifrício nos primeiros dias de uso do mesmo, além de ausência do sabor refrescante (média entre os grupos B e C igual a 3,93\%). Destaca-se aqui que foi feita limpeza com 
jato pra remoção somente das manchas e da fucsina no exame de 6 semanas o que mostra, através do exame de 12 semanas, que a quantidade de manchas formada nesse último período, manteve um padrão de formação.

Em nenhum grupo houve a solicitação para realização de limpeza das manchas por questões estéticas durante os intervalos dos exames.

Outros autores também verificaram o manchamento menos intenso com o uso de dentifrícios em comparação aos bochechos com clorexidina $\left(\right.$ FLOTRA $^{64}, 1973$; SANZ et al. $\left.{ }^{140}, 1994\right)$. Durante a escovação dentária, o contato mecânico das cerdas da escova acaba favorecendo o aparecimento de manchas mais suaves e na grande maioria delas imperceptível. Considerando os grupos B e C, nos exames de 6 semanas, 16,53\% dos participantes relataram que seus dentes estavam mais brancos, enquanto que no último exame, esse valor médio subiu para $40,38 \%$. Durante todo o período de pesquisa, apenas 5,67\% relataram perceber seus dentes mais amarelados ou escuros.

O efeito manchamento também poder ser visto como uma prova da estabilidade da clorexidina nos dentifrícios (DOLLES; ERIKSEN; GJERMO ${ }^{55}$, 1979).

Apesar da redução do índice de tártaro encontrada no grupo A no exame de 6 semanas, não foi verificada outras alterações neste índice, tanto considerando o aumento como redução do mesmo. Essa redução pode ser interpretada como sendo resultante da limpeza realizada após o exame baseline e da velocidade de formação de cálculo que varia de acordo com cada indivíduo e depende da composição da saliva, do fluido do sulco gengival, entre outros (CARRANZA, NEWMAN $\left.{ }^{39}, 1996\right)$. Mesmo que alguns estudos relatem um possível incremento nos índices de tártaro com o uso da clorexidina (CIANCIO ${ }^{45}$, 1995; ANDERSON et al. $\left.{ }^{6}, 1997\right)$, neste estudo tal fato não foi observado. SINNES et al. ${ }^{153}$, 1997, afirmam que pode-se verificar um pequeno aumento nas deposições calcificadas supragengivais. BASSIOUNY; GRANT ${ }^{23}, 1975$ e SANZ et al. ${ }^{140}, 1994$, não encontraram 
alterações significantes no acúmulo de cálculo quando da utilização da clorexidina.

De acordo com os resultados verificados nesse estudo, o uso terapêutico de dentifrícios com clorexidina, adicionados ou não de flúor, pode ser indicado como um coadjuvante na higienização bucal.

Importante também é considerar que, apesar da clorexidina ser uma grande aliada à odontologia, seu uso deve ser baseado em critérios e diagnósticos, com monitoramento adequado e com a freqüência de aplicação sendo prescrita com base nas características da doença e do paciente $\left(\mathrm{CURY}^{47}, 1999\right)$.

Como foi observado, principalmente nos exames baseline, pacientes ortodônticos apresentam alguns fatores de risco à cárie e doenças gengivais, principalmente por terem um número adicional de superfícies retentoras de placa na cavidade bucal (HEINTZE ${ }^{86}$, 1996; TAMBURUS; BAGATIN; NETTO ${ }^{161}$, 1998; GLANS; LARSON; OGAARD ${ }^{76}$, 2003; DERKS et al. ${ }^{53}$, 2004). O uso dos dentifrícios com clorexidina melhorou as condições bucais dos mesmos, podendo ser visto como uma alternativa promissora no controle de placa, gengivite e sangramento.

Os dentifrícios com clorexidina que foram administrados nessa pesquisa ainda não estão comercialmente disponíveis. Eles estão em processo de avaliação.

Mesmo com outros veículos de administração da clorexidina já existentes (CARVALHO et al. ${ }^{40}, 1991$; TORRES $^{162}, 2000 ;$ JONES $^{97}$, 2000), o seu uso em dentifrícios poderia ser considerado como uma forma prática e eficaz, com efeitos colaterais basicamente restritos às manchas extrínsecas, esteticamente aceitáveis e reversíveis. 
CONCLUSÕES 


\section{Conclusões}

Nesse estudo verificou-se que:

1. As reduções estatisticamente significantes dos valores dos índices gengival, de sangramento e de placa observadas nos grupos B e C, sugerem que os dentifrícios com clorexidina (0,95\%), adicionados ou não de flúor, foram mais eficazes que o dentifrício controle.

2. Considerando o manchamento extrínseco de esmalte dentário como o efeito adverso mais comum quando da utilização da clorexidina, foi possível observar o aumento estatisticamente significante dos valores do Índice de Manchas nos grupos que utilizaram os dentifrícios com clorexidina (adicionados ou não de flúor). Em relação ao cálculo dentário, não houve aumento.

3. A utilização do fluoreto de sódio juntamente com a clorexidina não provocou a inativação da mesma, pois, na redução dos índices gengival, de placa e de sangramento, houve desempenho semelhante das formulações com e sem flúor.

4. O uso terapêutico de dentifrícios com clorexidina (adicionados ou não de flúor) poder ser visto como uma forma simples e eficaz de administração do agente químico, visto que não interfere na rotina de higienização do paciente ao ser aplicada nos momentos da escovação dentária.

5. Pacientes em tratamento ortodôntico fixo merecem maior atenção dos cirurgiões-dentistas no que se refere à prevenção e terapêutica para a manutenção da saúde bucal. Quando necessária, a prescrição racional de agentes químicos, como a clorexidina, seria uma forma promissora para se alcançar melhoras. 
ANEXOS 

ANEXO 1. Modelo da carta de informação entregue aos participantes da pesquisa.

\section{CARTA DE INFORMAÇÃO}

Esta pesquisa tem o objetivo de analisar a ação de uma pastas de dentes na saúde bucal de pacientes em tratamento ortodôntico. Estas pastas terão em sua composição flúor, clorexidina ou clorexidina com flúor, que são produtos muito utilizados na Odontologia. Durante a pesquisa será fornecido aos participantes da pesquisa os produtos para que realizem a escovação dentária em suas casas. Durante este período, os participantes não poderão utilizar outros produtos químicos para sua higiene bucal. Serão agendados os dias para a realização de exames bucais nos participantes da pesquisa, que terão sua identidade mantida em segredo. Informamos que os produtos utilizados nesta pesquisa são eficazes para melhorar a saúde bucal e que, os produtos com clorexidina podem causar alguma coloração marrom nos dentes e isto é resolvido com a limpeza feita pelo dentista. Em qualquer momento o participante pode se recusar a continuar na pesquisa sem sofrer algum dano ou discriminação e, caso queira apresentar reclamações em relação a sua participação na pesquisa, poderá entrar em contato com o Comitê de Ética em Pesquisa em Seres Humanos, da FOB-USP, pelo endereço da Al. Dr. Octávio Pinheiro Brisolla, 9-75 (sala no prédio da Biblioteca, FOB/USP) ou pelo telefone (14)3235-8356. 
ANEXO 2. Modelo do consentimento livre e esclarecido assinado pelos participantes da pesquisa (maiores de idade).

\section{TERMO DE CONSENTIMENTO LIVRE E ESCLARECIDO}

\section{(para maiores de idade)}

Pelo presente instrumento que atende às exigências legais, o Sr. (a)

portador da cédula de identidade , após

leitura minuciosa da CARTA DE INFORMAÇÃO, devidamente explicada pelos profissionais em seus mínimos detalhes, ciente dos procedimentos aos quais será submetido, não restando quaisquer dúvidas a respeito do lido e explicado, firma seu CONSENTIMENTO LIVRE E ESCLARECIDO concordando em participar da pesquisa proposta. Fica claro que o sujeito da pesquisa ou seu representante legal, pode a qualquer momento retirar seu CONSENTIMENTO LIVRE E ESCLARECIDO e deixar de participar desta pesquisa e ciente de que todas as informações prestadas tornaram-se confidenciais e guardadas por força de sigilo profissional (Art. $9^{\circ}$ do Código de Ética Odontológica). Por estarem de acordo assinam o presente termo. Bauru-SP, de de 2004.

Assinatura do Participante 
ANEXO 3. Modelo do consentimento livre e esclarecido assinado pelos participantes da pesquisa (menores de idade).

\section{TERMO DE CONSENTIMENTO LIVRE E ESCLARECIDO}

\section{(para menores de idade)}

Pelo presente instrumento que atende às exigências legais, o Sr. (a) portador da cédula de

identidade , após leitura minuciosa da CARTA

DE INFORMAÇÃO, devidamente explicada pelos profissionais em seus mínimos detalhes, ciente dos procedimentos aos quais seu (sua) filho (a) , portador da cédula de identidade , será submetido (a), não restando quaisquer dúvidas a respeito do lido e explicado, firma seu CONSENTIMENTO LIVRE E ESCLARECIDO autorizando-o (a) a participar da pesquisa proposta. Fica claro que o sujeito da pesquisa ou seu representante legal, pode a qualquer momento retirar seu CONSENTIMENTO LIVRE E ESCLARECIDO e deixar de participar desta pesquisa e ciente de que todas as informações prestadas tornaram-se confidenciais e guardadas por força de sigilo profissional (Art. $9^{\circ}$ do Código de Ética Odontológica). Por estarem de acordo assinam o presente termo.

Bauru-SP de de 2004.

Ass. Participante de Pesquisa

$\overline{\text { Ass. Responsável pelo participante }}$ 
ANEXO 4. Grupos A, B e C balanceados.

\begin{tabular}{|c|}
\hline GRUPO A \\
\hline 27 voluntários: 13 homens e 14 mulheres \\
\hline Idade média: 16,9 anos \\
\hline Idade mínima: 13 anos \\
\hline Idade máxima: 32 anos \\
\hline Índice Gengival = 1,21 \\
\hline Índice de Placa $=83$ \\
\hline
\end{tabular}

\begin{tabular}{|c|}
\hline GRUPO B \\
\hline 28 voluntários: 14 homens e 14 mulheres \\
\hline Idade média: 16,6 anos \\
\hline Idade mínima: 14 anos \\
\hline Idade máxima: 24 anos \\
\hline Índice Gengival $=1,17$ \\
\hline Índice de Placa $=78$ \\
\hline
\end{tabular}

\begin{tabular}{|c|}
\hline GRUPO C \\
\hline 28 voluntários: 13 homens e 14 mulheres \\
\hline Idade média: 16,7 anos \\
\hline Idade mínima: 14 anos \\
\hline Idade máxima: 25 anos \\
\hline Índice Gengival $=1,21$ \\
\hline Índice de Placa $=82$ \\
\hline
\end{tabular}


ANEXO 5 - Carta com as instruções aos participantes.

Informações ao paciente:

- Você recebeu pasta de dentes suficiente para ser utilizada até o próximo exame.

- Todos os tubos de pasta, mesmo que vazios, deverão ser entregues no próximo dia de exame, para que possamos repor os novos tubos.

- Como você está participando de uma pesquisa, orientamos para que esta seja a sua pasta de dentes, não podendo ser utilizada por outras pessoas de sua família e/ou amigos.

- É necessário que você escove seus dentes 3 vezes por dia com a pasta e a escova que recebeu. As outras vezes que você quiser escovar os dentes, escove sem pasta. Na hora da escovação, coloque uma quantidade de pasta suficiente que cubra toda e extensão da escova e escove por 2 minutos.

- O fio dental deve ser sempre utilizado para garantir o sucesso de sua higiene.

- Durante este período que você estará na pesquisa, nenhum outro produto de higiene bucal poderá ser usado.

- Quando você for ao seu dentista, ele também não poderá fazer nenhuma limpeza em você, pois nós já fizemos e precisamos controlar até a próxima limpeza como a sua saúde bucal vai ficar.

- Se você tiver que tomar algum remédio durante a pesquisa, nós precisaremos ser avisadas.

- Nós iremos telefonar para você periodicamente para acompanhar a sua participação na pesquisa.

- Se você tiver alguma dúvida, ligue para nós: 32227719 ou 32279614.

Agradecemos a sua colaboração. 
ANEXO 6. Modelo do questionário inicial.

1. Quantas vezes por semana você consome um destes produtos: chá preto/mate, vinho tinto, café, refrigerante (coca-cola, fanta)?
( ) 1 vez
( ) 2 vezes
( ) 3 vezes
( ) mais de 3 vezes

( ) outro:

2. Quais produtos de higiene bucal você utilizava antes de iniciar esta pesquisa?

( ) escova de dentes ( ) pasta de dentes ( ) fio dental ( ) passa-fio

( ) escova interdental ( ) escova unitufo ( ) nenhum

( ) Bochecho:

( ) outro:

3. Quantas vezes ao dia você escovava seus dentes antes do início desta pesquisa?
( ) 1 vez
( ) 2 vezes
( ) 3 vezes
( ) mais de 3 vezes
( ) nenhuma

4. Após a colocação de seu aparelho, você recebeu recomendações sobre higiene bucal do (da) seu (sua) dentista? Se sim, qual (is)?

R.: 
ANEXO 7. Modelo do questionário de acompanhamento.

1. Quantas vezes por dia você tem escovado seus dentes desde o seu último exame? Se algum dia houve alguma mudança na freqüência de escovação, explique.

R.:

2. Desde o início do tratamento, você esqueceu e usou outra pasta de dentes diferente da recomendada? Quantas vezes isto aconteceu? $\mathrm{R}$ :

3. Você está tendo alguma dificuldade em seguir as orientações do tratamento? Se a resposta for sim, qual (is)?

R.:

4. Após o início do tratamento, você percebeu alguma mudança na sua boca? Se a resposta for sim, qual (is)?

R.: 
ANEXO 8. Modelo da ficha de exame.

Nome:

Idade: Gênero:

Data do exame: No. do exame: $1^{\circ} . / 2^{\circ} . / 3^{\circ}$ Código:

\section{Índice de Manchas}

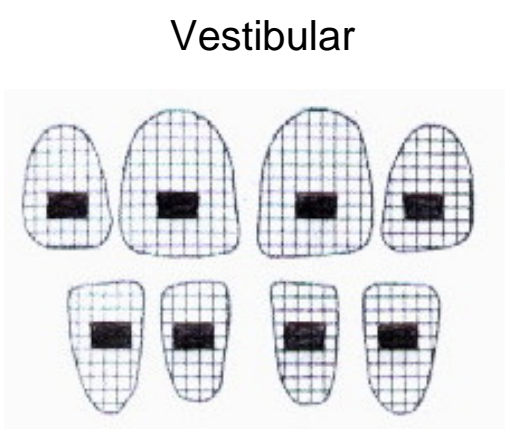

Lingual

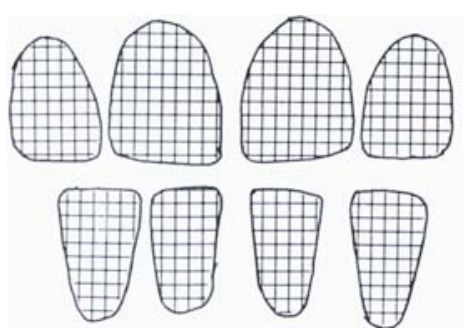

\section{Índice de Tártaro}

\begin{tabular}{|l|l|l|l|l|l|l|l|l|l|l|l|l|l|l|l|l|}
\hline SL & & & & & & & & & & & & & & & & \\
\hline SV & & & & & & & & & & & & & & & & \\
\hline & 8 & $\mathbf{7}$ & $\mathbf{6}$ & $\mathbf{5}$ & $\mathbf{4}$ & $\mathbf{3}$ & $\mathbf{2}$ & $\mathbf{1}$ & $\mathbf{1}$ & $\mathbf{2}$ & $\mathbf{3}$ & $\mathbf{4}$ & $\mathbf{5}$ & $\mathbf{6}$ & $\mathbf{7}$ & $\mathbf{8}$ \\
\hline IV & & & & & & & & & & & & & & & & \\
\hline IL & & & & & & & & & & & & & & & & \\
\hline
\end{tabular}

0 - inexistência de tártaro.

1 - tártaro supra em não mais que $1 / 3$ da superfície exposta do dente.

2 - tártaro supra cobrindo mais que $1 / 3$, mas não mais que $2 / 3$ da superfície exposta em torno da região cervical.

3 - tártaro supra cobrindo mais que 2/3 da superfície da coroa ou uma faixa contínua e espessa de tártaro subgengival.

$X$ - dente inexistente/excluído. 


\section{Índice gengival}
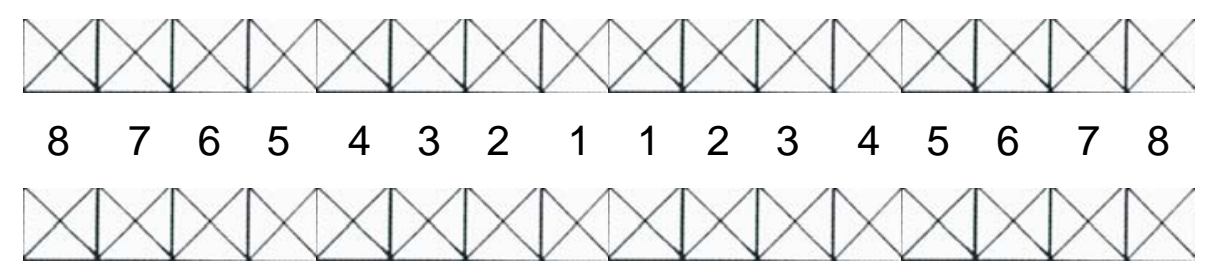

0 - Ausência de inflamação = gengiva uniformemente rosada .

1 - Inflamação leve = modificação pequena na cor e textura gengivais .

2 - Inflamação moderada = gengiva moderadamente avermelhada, vítrea, edemaciada e hipertrófica, com sangramento sob estímulo.

3 - Inflamação severa = gengiva nitidamente avermelhada, hipertrófica, com tendência ao sangramento espontâneo e presença de ulceração.

\section{Índice de sangramento}

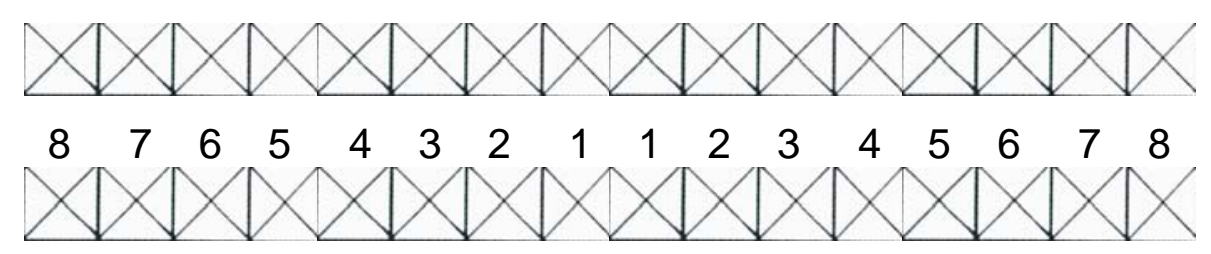

\section{Índice de placa ortodôntico}

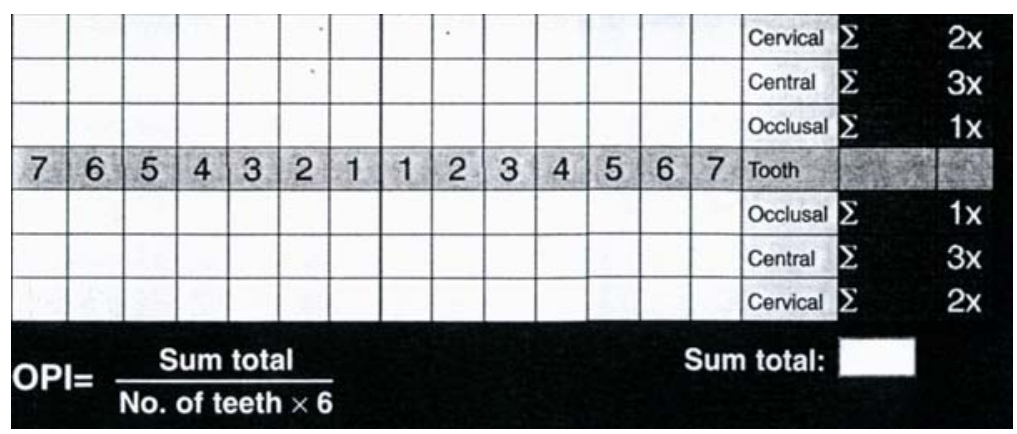


REFERÊNCIAS BIBLIOGRÁFICAS 


\section{REFERÊNCIAS BIBLIOGRÁFICAS*}

1. ADDY, M. et al. Comparison of two commercially available chlorhexidine mouthrinses. Staining and antimicrobial effects in vitro. Clin Prev Dent, v.11, p.10-14, 1989.

2. ADDY, M.; MORAN, J. Extrinsic tooth discoloration by metals and chlorhexidine II. Clinical staining produced by chlorhexidine, iron and tea. Brith Dent J, v.159, n.9, p.33134, Nov. 1985.

3. AINAMO, J.; BAY, I. Problems and proposals for recording gingivitis and plaque. Int Dent J, v.25, p.229-35, 1975.

4. ALEXANDER, C. M.; JACOBS, J. D.; TURPIN, D. L. Disease control in an orthodontic practice. Amer. J. Orthodont., v. 71, n. 1, p. 79-93, Jan. 1977.

5. ALSTAD, S.; ZACHRISSON, B.V. Longitudinal study of periodontal condition associated with orthodontic treatment in adolescents. Am J Ortodont, v.76, n.3, p.277-86, Sept., 1979.

6. ANDERSON, G.B. et al. Clinical effects of chlorhexidine muothwashes on patients undergoing orthodontic treatment. Am J Orthod Dentof Orthop, v.111, n.6, p.606-12, 1997.

7. ARSENIAN, M.B.; PEREZ, F.E.G.; NUNES, F.D. Uso da clorexidina $0,12 \%$ (Periogard) em pacientes portadores de paralisia cerebral -um estudo preliminar. Rev Inst Ciênc Saúde, v.10, n.2, p.43-45, jul./dez. 1992.

* Normas recomendadas para uso no âmbito da Universidade de São Paulo, com base no documento "Referências Bibliográficas: exemplos", emanado do Conselho Supervisor do Sistema Integrado de Bibliotecas da USP, em reunião de 20 de setembro de 1990. 
8. AXELSSON, P. Current role of pharmaceuticals in prevention of caries and periodontal disease. Int Dent J, v.43, n.5, p.47382, Oct. 1993.

9. AXELSSON, P.; LINDHE, J. Efficacy of mouthrinses in inhibiting dental plaque and gingivitis in man. J Clin Periodontol, v.14, p.205-12, 1987.

10. AZEVEDO, E.L. de. et al. Higiene bucal em Ortodoncia. J Bras Ortod Ortop Facial, v.6, n.1, p.25-29, jan./fev. 2001.

11. AZEVEDO, M.P. et al. Análise da saúde em ratos após uso de clorexidina. Anais da XIII Reunião Anual da Sociedade Brasileira de Pesquisa Odontológica, p.134, 1996.

12. BACCHI, E. O. S.; PRATES, N. S.; ATTIZZANI, A. Profilaxia buco-dental em Ortodontia. Rev. gaúcha Odont., v. 45, n. 6 , p. 342-6, nov/dez.1997.

13. BAKER, K. Mouthrinses in the prevention and treatment of periodontal disease. Curr Opin in Periodontol, v.1, p.89-96, 1993.

14. BALENSEIFEN, J.W.; MADONIA, J.V. Study of dental plaque in orthodontics patients. J Dent Res, v.49, n.2, p.320-324, 1970.

15. BALL, D. M.; BALL Jr, E. L. Comparative effectiveness of two mouthwashes used after gingivectomy. J. Periodont., v. 38, p. 395-7, 1967.

16. BARKVOLL, P.; ROLLA, G.; SVENDSEN, A.K. Interaction between chlorhexidine digluconate and sodium lauryl sulfate in vivo. J Clin Periodontol, v.16, p.593-95, 1989.

17. BARLETTA, O.B.; ALIVERTI, M.M.; BUTTA, M.A. El uso del gluconato de chlorhexidine en el contralor de la placa bacteriana. Rev Assoc Odontol Argent, v.65, p.27-31, 1977.

18. BARNES, G. P. et al. Effects of two cetylpyridinium chloride containing mouthwashes on bacterial plaque. J. Periodont., v. 47, n. 7, p. 419-22, July. 1976. 
19. BARROS, L.M.; FIORINI, J.E. Efeito da clorexidina e da água ozonizada sobre os $\mathrm{S}$. viridans da placa bacteriana supragengival. Rev Assoc Paul Cirurg Dent, v.54, n.1, p.4752, jan./fev. 2000.

20. BARROS, V. M. R. et al. Efeito das diferentes concentrações de cloreto de cetilpiridínio na anti-sepsia do sulco gengival. Rev. Fac. Farm. Odontol. Ribeirão Preto., v. 13, p. 115-26, 1976.

21. BARROS, V.M.R. et al. Estudo comparativo da eficiência de três métodos de anti-sepsia intrabucal na redução do número de estreptococos do sulco gengival. Rev Odontol Univ São Paulo, v. 12, n. 3, p. 201-206, jul./set. 1998.

22. BASRANI, B. et al. Substantive antimicrobial activity in chlorhexidine-treated human root dentin. Oral Surg, v.94, n.2, p.240-5, Aug. 2002.

23. BASSIOUNY, M.A.; GRANT, A.A. The toothbrush application of chlorhexidine. Brit Dent J, v.139, p.323-27, Oct. 1975.

24. BASTOS, J.R. de M.; LOPES, E.S.; RAMIRES, I. Odontologia preventiva e social. Bauru, 2001. p.95-108. Manual. Faculdade de Odontologia de Bauru, Universidade de São Paulo.

25. BASTOS, J.R. de M.; HEINTZE, S.D.A. Prevenção primáriaprimária. Jornal da ABOPREV, v.7, p.14, mar./jun. 1996.

26. BASTOS, J.R de M.; HENRIQUES, J.F.C.; OLYMPIO, K.P.K. Prevenção de cárie e doença periodontal em pacientes sob tratamento ortodôntico. Manual didático. Faculdade de Odontologia de Bauru, Universidade de São Paulo, 2001.

27. BELLINI, H.T. et al. Uso da clorexidina no controle da placa e da gengivite. Rev Assoc Paulista Cirurg Dent, v.34, n.4, p.276-82, jul./ago. 1980.

28. BLOOM, R.G.; BROW, R.L. Study of the effects orthodontic appliances on the oral microbiol flora. Oral Surg and Oral Pathol, v.17, n.5, p.658-61, May 1964. 
29. BONESVOLL, P. Oral pharmacology of chlorhexidine. J Clin Peridodontol, v.4, n.49, 1977.

30. BOUWSMA, O.J. The status, future, and problems of oral antiseptics. Curr Opin in Periodontol, v.3, p.78-84, 1996.

31. BOYD, R.L. Enhancing the value of orthodontic treatment: incorporating effective preventive dentistry into treatment. Am J Orthod and Orthop, v.117, n.5, p.601-3, May 2000.

32. BOYD, R.L.; BAUMRIND, S. Periodontal considerations in the use of bonds or bands on molars in adolescents and adults. Angle Orthodont, v.62, n.2, p.117-26, 1992.

33. BOWEN, D. Personal mechanical oral hygiene care and chemotherapeutic plaque control. In: Dental Hygiene. Theory and pratice. Cap. 16, p.451-6, 1999.

34. BRECX, M. et al. Long-term effects of meridol and chlorexidine mouthrinses on plaque, gingivites, staining and bacterial vitality. J Dent Res., v.72, n.8, p.1194-7, Aug.1993.

35. BRIGHTMAN, L.J. et al. The effects of a $0.12 \%$ chlohexidine gluconate mouthrinse on orthodontic patients aged 11 through 17 with established gingivitis. Am J Orthod Dentofac Orthop, v.100, n.4, p. 324-329, Oct. 1991.

36. BRINER, W.W. et al. Assessment of susceptibility of plaque bacteria to chlorhexidine after 6 months oral use. J Dent Res, v.17, p.53-59, 1980.

37. BUDTZ-JÖRGENSEN, E.; LÖE, H. Chlorexidine as a denture desinfetant in the treatment of denture stomatitis. Scand. J. Dent. Res., v.80, p.457-464, 1972.

38. CANCRO, L.P. et al. Dose response of chlorhexidine gluconate in a model in vivo plaque system. J Dent Res, v.53, p.765, 1974.

39. CARRANZA, F.A.; NEWMAN, M.G. Periodontia Clínica. Guanabara Koogan. 8 ed. p. 371-384, 1996. 
40. CARVALHO, L.E.P. et al. Clorexidina em Odontologia. Rev Gaúcha Odontol, v.39, n.6, p.423-27, nov./dez. 1991.

41. CASE, D.E. Safety of Hibitane. Laboratory experiments. J Clin Periodontol, v.4, p.66, 1977.

42. CASTELLANOS. N. N. Formulación de acetato de clorexidina como colutório. Rev. Cub. Farmacol., v. 21, p. 95-101, 1987.

43. CHADWICK, B.L. Orthodontic products update - Products for prevention during orthodontics. Brit J Orthod, v.21, n.4, p.395-98, 1994.

44. CHEYNE, V. D.; RICE, T. B. Effects of topically applied fluorine on human dental caries, including a method for its application.

J. dent. Res., v. 21, n. 3, p. 320, 1942.

45. CIANCIO, S.G. Mechanical and chemical supragingival plaque control. Periodontology 2000, v.8, p.75-86, 1995. Apud IACONO, V.J. et al. Modern supragingival plaque control. Int Dent J, v.48, n.1, p.290-97, June 1998.

46. CIANCIO, S.G. Use of mouthrinses for professional indications. J Clin Periodontol, v.15, p.520-23, 1988.

47. CURY, J.A. Controle químico da placa dental. In: PINTO,V.G. Aboprev: promoção da saúde bucal. 2ed. São Paulo, Artes Médicas, cap.7, p.130-40. 1999.

48. DEL BEL CURY, A.A.; REBELO, M.A.B.; CURY, J.A. Efeito de bochecho com clorexidina $(\mathrm{CH})$ e flúor $(F)$ na redução de formação de placa dental e incorporação de flúor no esmalte dental. Rev Bras Odontol, v.51, n.3, p.26-29, maio/jun. 1994.

49. DE LA ROSA, M.; STURZENBERGER, O. P. Clinical reduction of gingivitis throught the use of a mouthwashcontaining two quaternary ammonium compounds. J. Periodont., v. 47, n. 9, p. 535-7, 1976. 
50. DELILBASE, C.; SARACOGLU, U.; KESKIN, A. Effects of 0,2\% chlorhexidine glugonate and amoxicilin plus clavulanic acid on the prevention of alveolar osteitis following mandibular third molar extractions. Oral Surg, v.94, n.3, p.301-4, 2002.

51. DePAOLA, L.G. et al. Chemotherapeutic inhibition of supragingival dental plaque and gingivitis development. J Clin Periodontol, v.16, p.311-15, 1989.

52. DENES, J.; GÁBRIS, K. Results of a 3-year oral hygiene programme including amine fluoride products in patients treated with fixed orthodontic appliances. Europ. J. Orthodont., v. 13, n. 2, p. 129-33, Apr. 1991.

53. DERKS, A. et al. Caries-inhibiting effect of preventive measures during orthodontic treatment with fixed appliances. Caries Res, v.38, n.5, p.413-20, Sep./Oct. 2004.

54. DIAMANTI-KIPIOTI, A.; GUSBERTI, F.A.; LANG, N.P. Clinical and microbiological effects of fixed orthodontic appliances. $\mathbf{J}$ Clin Periodontol, v.14, n.6, p.326-33, 1987.

55. DOLLES, O.K.; ERIKSEN, H.M.; GJERMO,P. Tooth stain during 2 years' use of chlorhexidine and fluoride containing dentifrices. Scand J Dent Res, v.87, n.4, p.268-74, Aug. 1979.

56. DOLLES, O.K.; GJERMO, P. Caries increment and gingival status during 2 years' use of chlorhexidine and fluoride containing dentifrices. Scand J Dent Res, v.88, n.1, p.22-27, 1980.

57. DUBEY, R.; JALILI, V. P.; GARG, S. Oral hygiene and gingival status in orthodontic patients. J. Pierre Fauchard Acad., v. 7, n. 2, p. 43-54, June. 1993.

58. ELLINGSEN, J.E.; ROLLA, G.; ERIKSEN, H.M. Extrinsic dental stain caused by chlorhexidine and other denaturing agents. J Clin Periodontol, v.9, p.317-22, 1982. 
59. ELWORTHY, A. et al. The substantivity of a number of oral hygiene products determined by the duration of effects on salivary bacteria. J Periodontol, v.67, p.572-76, 1996.

60. FAYLE, S.A.; DUGGAL, M.S.; WILLIAMS, S.A. Oral problems and the dentist's role in the management of paediatric oncology patients. Dent Update, v. 19, p.152-159, May 1992.

61. FEIST, I.S.; MICHELI, G. de.; SARIAN, R. Clorexidina: prós e contras. Rev Assoc Paulista Cirurg Dent, v.43, n.1, p.2023, jan./fev. 1989.

62. FELIU, J.L. Long-term benefits of orthodontic treatment on oral hygiene. Am J Orthod, v.82, n.6, p.473-77, Dec. 1982.

63. FERRAZ et al. In vitro assessment of the antimicrobial action and the mechanical ability of chlorhexidine gel as an endodontic irrigant. J Endod, v.27, p.7, n.452-5, Jul. 2001

64. FLOTRA, L. Different modes of chlorexidine application and related local side effects. J Periodontol Res, v.8, n.12, p.4144, Sept. 1973.

65. FRANDSEN, A. Mechanical oral hygiene pratices. In: LÖE, H.; KEINMAN, D.V. Dental plaque control measures and oral hygiene pratices. Oxford, IRL, 1986, p.93-116.

66. FREITAS, C.S. et al. Evaluation of the substantivity of chorhexidine in association with sodium fluoride in vitro. Pesq Odontol Bras, v.17, n.1, jan./mar. 2003.

67. GARIB, D.G. et al. Efeito do uso do gluconato de clorexidina e do cloreto de cetilpiridínio, em bochechos, como meio complementar da higiene bucal em pacientes sob tratamento ortodôntico. Ortodontia, v.30, n. 2, p.21-30, maio/ago, 1997.

68. GEIGER, M. A. et al. The effect of a fluoride program on white spot formation during orthodontic treatment. Amer. J. Orthodont. Dentofac. Orthop., v. 93, n. 1, p. 29-37, Jan. 1988. 
69. GERÔNIMO, D. H.; TOGASHI, A. Y.; HENRIQUES, J. F. Avaliação comparativa dos efeitos dos acessórios ortodônticos na saúde gengival e no índice de placa em pacientes com e sem orientação sobre métodos de higiene bucal. Ortodontia, v. 27, n. 3, p. 27-33, set./dez. 1994.

70. GJERMO, P. A clorexidina na prática odontológica. Rev Gaúcha Odontol, v.26, n.1, p.22-26, jan./mar. 1978.

71. GJERMO, P. Chlorhexidine and related compounds. J Dent Res, v.68, p.1602-08, 1989.

72. GJERMO, P. Chlorhexidine in dental practice. J Clin Periodontol, v.1, p.143-52, May 1974.

73. GJERMO, P. et al. The plaque-inhibitting capacity of 11 antibacterial compounds. J Periodont Res, v.5, n.2, p.102109, 1970.

74. GJERMO, P.; ROLLA, G. Plaque innibition by antibacterial dentifrices. Scand J Dent Res, v.78, p.464-70, 1970.

75. The plaque inhibiting effect on chlorhexidine containing dentifrices. Scand J Den Res, v.79, p.1232, 1971.

76. GLANS, R.; LARSSON, E.; OGAARD, B. Longitudinal changes in gingival condition in crowded and noncrowded dentitions subjected to fixed orthodontic treatment. Am J Orthod Dentofacial Orthop, v.124, n.6, p.679-82, Dec. 2003.

77. GORDON, J.; LAMSTER, I.; SEIGER, M. Efficacy of Listerine antiseptic in inhibiting the development of plaque and gingivitis. J Clin Periodontol, v.12, p.697-704, 1985.

78. GRECO, A.J.T. et al. Contribuição para o estudo da influência dos aparelhos ortodônticos fixos sobre o estado de higiene oral e as condições gengivais. Rev Fac Farm Odontol Araraquara, v.8, n.1, p.1-6, jan./jun. 1974.

79. GREENSTEIN, G.; BERMAN, C.; JAFFIN, R. Chlorhexidine: an adjunct to periodontal therapy. J Periodontol, v.57, p.36477, 1986. 
80. GRENE, J.C.; VERMILLOIN, J.R. The simplified oral hygiene index. J Am Dent Assoc, v.68, p.7-13, 1964.

81. GROSSMAN, E.; REITER, D.; STURZENBERGER, O.P. Sixmonth study of the effects of chlorhexidine mouthrinse on gingivitis in adults. J Periodontol Res, v.16, p.33-43, 1986.

82. GRÜNDEMANN, L.J. et al. Stain, plaque and gingivitis reduction by combining chlorhexidine and peroxy-borate. J Clin Periodontol, v.27, n.1, p.9-15, Jan. 2000.

83. GUGUSHE, T.S.; WET, F.A.; ROJAS-SILVA, O. Efficacy of an experimental dentifrice formulation on primary school children in Ga-Rankuwa, Pretoria. J Dent Assoc of South Africa, v.49, n.5, p.209-12, May 1994.

84. HAMP, S.E.; ROSLING, B.; LINDHE, J. Effect of chlorhexidine on gingival wound healing in the dog: a histometric study. $\mathbf{J}$ Clin Periodontol, v.2, p.143-52, 1975.

85. HAUGEN, E.; JOHANSEN, J.R. Penetration of oral mucosa of the guinea pig by radiolabelled chlorhexidine. Acta Odontol Scand, v.33, p.365, 1975.

86. HEINTZE, S.D. A profilaxia individual em pacientes com aparelhos fixos - recomendações para o consultório. Ortodontia, v.29, n.2, p.4-15, maio/ago. 1996.

87. HEINTZE, S.D. et al. Oral Health for the orthodontic patient. Quintessence. Illinois. p. 66-70, 1998.

88. HENNESSEY, T.D. Some antibacterial properties of chlorhexidine. J Periodont Res, v.8, p.61, 1973.

89. HERBERT, V.R. et al. Methodology for quantifying residues of chlorhexidine in raw dairy milk. J Agric Food Chem, v.51, n.3, p.567-70, Jan. 2003.

90. IACONO, V.J. et al. Modern supragingival plaque control. Int Dent J, v.48, n.1, p.290-97, June 1998.

91. JEFFCOAT, M.K. at al. Adjunctive use of a subgingival controlled-release chlorhexidine chip reduces probing depth 
and improves attachment level compared with scaling and root planing alone. J Periodontol, v.69, n.9, p.989-97, 1998.

92. JENKINS, S.; ADDY, M.; NEWCOMBE, R. Dose response of chlorhexidine against plaque and comparison with triclosan. J Clin Periodontol, v.21, p.250-55, 1994.

93. . Evaluation of a mouthrinse containing chlorhexidine and fluoride as an adjunct to oral hygiene. J Clin Periodontol, v.20, p.20-25, 1993.

94. The effects of a chlorhexidine toothpaste on the development of plaque, gingivitis and tooth staining. J Clin Periodontol, v.20, p.59-62, 1993.

95. . The effects of $0.5 \%$ chlorhexidine and $0.2 \%$ triclosan containing toothpastes on salivary bacterial counts. J Clin Periodontol, v.17, p.85-89, 1990.

96. JENKINS, S.; ADDY, M.; WADE, W. The mechanism of action of chlorhexidine: a study of plaque growth on enamel inserts in vivo. J Clin Periodontol, v.15, p.415-24, 1988.

97. JONES, C.G. Chlorhexidine: is it still the gold standart? Periodontol 2000, v.15, p.55-62, Oct. 1997.

98. JOYSTON-BECHAL, S. Prevention of dental diseases following radiotherapy and chemotherapy. Int Dent J, v.42, n.1, p.4753, Feb. 1992.

99. JÚNIOR, O.C. et al. Efeitos de bochechos de clorexidina na saúde gingival em pacientes portadores de aparelhos ortodônticos. Rev Periodont, v.5, n.3, p.309-11, jan./jun. 1996.

100. LAMSTER, I.B. et al. The effect of Listerine antiseptic on the reduction of existing plaque and gingivitis. Clin Prev Dent, v.5, p.12-16, 1983.

101. LANG, N.P.; BRECX, M.C. Chlohexidine digluconate: an agent of plaque control and prevention of gingival inflammation. J Periodont Res, v.21, p.74-86, 1986. 
102. LANG, N.P. et al. Effects of supervised chlorhexidine mouthrinses in children. A longitudinal clinical trial. J Periodontol Res, v.17, p.101-11, 1982.

103. LASCALA, N.T.; MOUSSALLI, N.H. Periodontia clínica especialidades afins. Artes Médicas. São Paulo, p.219-29, 1984.

104. LINDHE, J. et al. Effect of local applications of chlorhexidine on the oral mucosa of hamster. J Periodont Res, v.5, p.177-82, 1970.

105. LÖE, H. Does chlorhexidine have a place in the prophylaxis of dental diseases? J Periodont Res, v.8, p.93-99, 1973.

106. LÖE, $H$. et al. Two years oral use of chlorhexidine in man. J Periodontol Res, v.11, n.3, p.135-44, 1976.

107. LÖE, H; SCHIOTT, C.R. The effect of mouthrinses and topical application of chlorhexidine on the development of dental plaque and gingivitis in man. J Periodont Res, v.5, p.79-83, 1970.

108. LÖE, H.; SILNESS, J. Periodontal disease in pregnancy. Acta Odontol Scand, v.21, p.533-51, 1963.

109. LOESCHE, W. Chemotherapy of dental plaque infections. Oral Sciences Rev, v.9, p.65-107, 1976. Apud PILLON, F. de L. Avaliação crítica dos recursos químicos para o controle da placa bacteriana supragengival. In: OPPERMANN, R.V.; RÖSING, C.K. Periodontia: ciência e clínica. São Paulo. Artes Médicas, 2001. Cap 3.3, p.105-18.

110. LUCAS, G.Q.; LUCAS, O.N. Efecto de la Clorhexidina en pacientes con aparatos de ortodoncia. Rev Assoc Odontol Argent, v.85, n.4, p.355-60, ago./sep. 1997.

111. LUNDSTRÖN, F.; HAMP, S.E. Effect of oral hygiene education on children with and without subsequent orthodontic treatment. Scand J Dent Res, v.88, p.53-59, 1980. 
112. MACHADO, W.A.S. et al. A clorexidina no controle de placa em pacientes internados: estudo piloto. Rev Bras Odontol, v.59, n.6, p.390-392, nov./dez. 2002.

113. MACKENZIE, I.C. et al. Two years oral use of chlorhexidine in man. Effects on stratum corneum or oral mucosa. $\mathbf{J}$ Periodont Res, v.11, p.165, 1976.

114. MAGNUSSON, B.; HEYDEN,G. Autoradiographic studies of ${ }^{14} \mathrm{C}$ chlorhexidine given orally in mice. J Periodont Res, v.8, p.49, 1973.

115. MANDEL, I.D. Antimicrobial mouthrinses: overview and update. J Am Dent Ass, v.125, p.2-10, 1994.

116. MATOS, M.S. de. Controle químico e mecânico de placa em pacientes ortodônticos. Uma análise por grupos de dentes de acordo com o acessório ortodôntico empregado. Rev Dental Press Ortodon Ortop Facial, v8, n.1, p.87-93, jan./fev. 2003.

117. MATTHIJS, S.; ADRIAENS, P.A. Chlorhexidine varnishes: a review. J Clin Periodontol, v.29, n.1, p.1-8, Jan, 2002.

118. MAYERSON, M. Management and marketing. J Clin Orthod, v.30, n.6, p.337-41, 1996.

119. MAYNARD, J.H. et al. A 6-month home usage trial of a $1 \%$ chlorexidine toothpaste - effects on the oral microflora. J Clin Periodontol, v.20, p.207-11, 1993.

120. MURRAY, J.J.; RUGG-GUNN, A.R. Fluorides in caries prevention. Dental Practioner Handbook, n.20, Bristol, John Wright \& Sons, 1982. Apud YATES, R. et al. A 6-month home usage trial of a $1 \%$ chlorhexidine toothpaste. J Clin Periodontol, v.20, n.2, p.130-38, 1993.

121. NEIDLE, E.A.; YAGELA, J.A. Farmacologia e terapêutica para dentistas. 3ed. Rio de Janeiro. Guanabara Koogan, 1991.

122. NEWMAN, H.N. Modes of application of antiplaque chemicals. J Clin Periodontol, v.13, p.965-74, 1986. 
123. NEWMAN, M.G.; KORNMAN, K.S. O uso de antibióticos e antimicrobianos na prática odontológica. São Paulo, Quintessence, 1997.

124. OLYMPIO K.P.K. et al. Prevenção de cárie dentária e doença periodontal em ortodontia: uma necessidade imprescindível. Rev Dental Press, 2004 (versão no prelo).

125. OPPERMANN, R.V.; RÖSING, C.K. Periodontia: ciência e clínica. Artes Médicas, São Paulo, p.5-9, 2001.

126. OWENS, J. et al. A short-term clinical study design to investigate the chemical plaque inhibitory properties of mouthrinses when used as adjuncts to toothpastes: applied to chlorhexidine. J Clin Periodontol, v.24, n.10, p.732-37, Oct. 1997.

127. PAVARINA, A.C. et al. An infection control protocol: effectiveness of immersion solutions to reduce the microbial growth on dental protheses. J Oral Rehabil, v.30, n.5, p.5326. May 2003.

128. PILLON, F. de L. Avaliação crítica dos recursos químicos para o controle da placa bacteriana supragengival. In: OPPERMANN, R.V.; RÖSING, C.K. Periodontia: ciência e clínica. São Paulo. Artes Médicas, 2001. Cap 3.3, p.105-18.

129. PUPPIN FILHO, A.; FEITOSA, A.C.R.; GANHOTO, M.R.A. O uso da clorexidina em pacientes submetidos a tratamento ortodôntico com aparelhos fixos. UFES Rev Odontol, v.3, n.1, p.24-31, jan./jun. 2001.

130. RINDOM-SCHIÖTT, C. et al. Two years oral use of chlorhexidine in man. J Periodontol Res, v.11, n.3, p.158-64, 1976.

131. RIVERA,S.; CAVIERES,X. Efectos de los colutorios com clorhexidina al $0,1 \%$ y $0,2 \%$ em pacientes com tratamiento ortodoncico. Periodontia, v.7, n.2, maio/ago., 1998.

132. ROBERTS, W.R.; ADDY, M. Comparison of the in vivo and in vitro antibacterial properties of antiseptic mouthrinses 
containing chlorhexidine, alexidine, cetyl pyridinium chloride and hexidine: relevance to mode of action. $\mathbf{J}$ Clin Periodontol, v.8, p.295-310, 1981.

133. RÖLLA, G.; LÖE, H.; SCHIÖTT, C.R. Retention of chlorhexidine in the human oral cavity. Arch Oral Biol, v.16, p.1109-16, 1971.

134. The affinity of chlorhexidine for hydroxyapatite and salivary mucins. J Periodont Res, v.5, p.90-95, 1970.

135. RÖLLA, G.; MELSEN,B. On the mechanism of plaque inhibition by chlorhexidine. J Dent Res, v.54, p.1357, 1975.

136. RUSSELL, B.G.; BAY, L.M. Oral use of chlorhexidine gluconate thoothpaste in epileptic children. Scand J Dent Res, v.86, n.1, p.52-57, 1978.

137. SADOWSKY, C.; BEGOLE, E.A. Long term effect of orthodontic treatment on periodontal health. Am J Orthod, v.80, n.2, p.156-72, Aug. 1981.

138. SAKAMAKI, S.T.; BAHN, A.N. Effect of orthodontic banding on localized oral lactobacilli. J Dent Res, v.47, n.2, p.275-9, Mar./Apr. 1968.

139. SANTOS, A. Evidence-based control of plaque and gingivitis. J Clin Periodontol, v.30, n.5, p.13-16, 2003.

140. SANZ, M. et al. The effect of a dentifrice containing chlorhexidine and zinc on plaque, gingivitis, calculus and tooth staining. $\mathbf{J}$ Clin Periodontol, v.21, p.431-37, 1994.

141. SCHAEKEN, M.J..M.; VAN DER HOEVEN,J.S.; VAN DER KIEBOOM, C.W.A. Effect of chlorhexidine varnish on streptocci in dental plaque from occlusal fissures. Caries Res., v.28, n.3, p.262-6, May/Jun. 1994.

142. SCHEIE, A.A.; ARNEBERG, P.; KROGSTAD, O. Effect of orthodontic treatment on prevalence of Streptococcus mutans in plaque and in saliva. Scand J Dent Res, v.92, p.211-17, 1984. 
143. SCHEIE, A.A. Modes of action of currently known chemical antiplaque agents other than chlorhexidine. J Dent Res, v.68, p.1909-16, 1989.

144. SCHIÖTT, C.R. et al. The effect of chlorhexidine mouth rinses on the human oral flora. J Periodont Res, v.5, p.84-6, 1970.

145. SCHIÖTT, C.R. The effect of chlorhexidine in the microflora of the oral cavity. J Periodont Res, v.8, p.7-10, 1973.

146. SCHIÖTT, C.R.; LÖE, H.; BRINER, W.W. Two years oral use of chlorhexidine in man. Effect on various medical parameters. J Peridont Res, v.11, p.158-9, 1976.

147. SCHWANINGER, B.; SCHWANINGER, N. V. Developing an effective oral hygiene program for the orthodontic patient: review, rationale and recommendations. Amer. J. Orthodont., v. 75, n. 4, p. 447-452, Apr. 1979.

148. SEGRETO, V.A. et al. A comparison of mouthwashes containing two concentrations of chlorhexidine. J Periodont Res, v.21, n.16, p.23-32, 1986.

149. SEKINO, S. et al. Effect of various chlorhexidine regimens on salivary bacteria and de novo plaque formation. J Clin Periodontol, v.30, n.10, p.919-25, Oct. 2003.

150. SHAW, L.; MURRAY, J.J. A new index for measuring extrinsic stain in clinical trials. Comm Dent Oral Epidemiol, v.5, p.116-20, 1977.

151. SHEIHAM, A. Dental cleanliness and chronic periodontal disease. Studies on British populations. Brit Dent J, v.129, p.413-18, 1970.

152. SILVA FILHO, O. G. et al. Programa supervisionado de motivação e instrução de higiene e fisioterapia bucal em crianças com aparelho ortodôntico. Rev. USP., v. 4, n. 1, p. 11-19, jan/mar. 1990.

153. SINNES, E.P. et al. Controle químico da placa bacteriana. In: LASCALA, N.T. Prevenção na clínica odontológica - 
Promoção de saúde bucal. São Paulo, Artes Médicas, 1997. Cap.11, p.173-85.

154. SMITH, I. et al. The effect of three dentifrices and a dental gel on plaque formation: a six week clinical study. Int Dent J, v.44, n.1, p.71-4, Feb. 1994.

155. SOARES, U. N.; ITO, I. Y.; ROCHA BARROS, V. M. da. Efeito da anti-sepsia da ferida cirúrgica alveolar sobre o crescimento bacteriano em fios de sutura de algodão. Pesqui Odontol Bras, v. 15, n. 1, p. 41-6, jan./mar. 2001

156. SOUZA, F. M. et al. Prevenção de cáries e doenças periodontais em ortodontia corretiva: métodos simples para serem usados no consultório. Ortodontia, v. 27, n. 3, p. 8792, set/dez. 1994.

157. SOUZA, N.M.; FALCÃO, A.F.P.; ARAÚJO, T.M. Higiene bucal no paciente ortodôntico. Rev Fac Odontol Univ Fed Bahia, v.18, p.60-67, jan/jun. 1999.

158. SREENIVASAN, P. et al. A rapid procedure to ascertain the antimicrobial efficacy of oral care formulations. Oral Microbiol Immunol, v.18, n.6, p.371-78, Dec. 2003

159. SREENIVASAN, P.; GAFFAR, A. Antiplaque biocides and bacterial resistance: a review. J Clin Periodontol, v.29, n.11, p.965-74, Nov. 2002.

160. STEFANI, C.M.; DE LIMA, A.F.M. Avaliação dos efeitos clínicos da aplicação de gel de clorexidina em pacientes sob tratamento ortodôntico. Periodontia, v.5, n.3, p. 300-5, jan./jun., 1996..

161. TAMBURUS, V.S.; BAGATIN, C.R.; SILVA NETTO, C.R. Higiene bucal no tratamento ortodôntico. Importância da motivação. Rev Fac Odontol Lins, v.11, n.1, p.51-57, jan./jun. 1998. 
162. TORRES, M.C.M. de. Utilização da clorexidina em seus diversos veículos. Rev Bras Odontol, v.57, n.3, p.174-80, maio/jun. 2000.

163. UETANABARO, T.; MARTINS, J.E.S.; ANDRADE, J.L.F de. Acúmulo de placa bacteriana em pacientes portadores de colagem direta e anéis convencionais. Rev Gaúcha Odontol, v.32, n.2, p.161-66, abr./jun. 1984.

164. VAN DER OUDERAA, F.J.G. Anti-plaque agents. Rationale and prospects for prevention of gingivitis and periodontal disease. J Clin Periodontol, v.18, p.447-54, 1991.

165. VAN GRUNSVEN, M.F.; CARDOSO, E.B.T. Atendimento odontológico em crianças especiais. Rev Assoc Paul Cirurg Dent, v.49, n.5, p.364-70, set/out. 1995.

166. van RIJKOM, H.M.; TRUIN, G.J.; van't HOF, M.A. A metaanalysis of clinical studies on the caries-inhibiting effect of chlorhexidine treatment. J Dent Res, v.75, n.2, p.790-95, Feb. 1996.

167. VILLALPANDO, K.T.; TOLEDO, S. Uso tópico do gel de Clorexidina a 1 por cento como agente redutor da placa dental e da inflamação gengival. RGO (Porto Alegre), v.45, n.1, p.17-22, jan./fev. 1997.

168. VINHOLIS, A.H.C. et al. Mecanismo de ação da clorexidina. Rev Periodont, v.5, n.3, p.281-83, jan./jun, 1996.

169. YATES, R. et al. A 6-month home usage trial of a $1 \%$ chlorhexidine toothpaste. J Clin Periodontol, v.20, n.2, p.130-38, 1993.

170. WAALER, R.; RÖLLA, G. Importance of theeth and tongue as possible receptor sites for chhlorhexidine in relation to its clinical effect. Scand J Dent Res, v.93, p.222-26, 1985.

171. WINROW, M.J. Metabolic studies with radiolabelled chlorhexidine in animals and man. J Periodont Res, v.8, p.45, 1973. 
172. ZACHRISSON, B. U. Oral hygiene for orthodontic patients: current concepts and pratical advice. Amer. J. Orthod., v. 66, n. 5, p. 487-97, Nov. 1974.

173. ZAMPATTI, O.; ROQUES, C.; MICHEL, G. An in vitro mouth model to test antiplaque agents: preliminary studies using a toothpaste containing chlorhexidine. Caries Res, v.28, n.1, p.35-42, Jan./Feb. 1994. 
ABSTRACT 


\begin{abstract}
The aim of this research was to analyze the effects of toothpastes with chlorhexidine (with or without fluorine) on the reduction of dental plaque, gingivitis and gingival bleeding in orthodontic patients, as well as to verify the occurrence of common side effect of chlorhexidine - the extrinsic staining of dental enamel and the dental calculus prevalence. A total of 83 patients participated this study. The patients used for 3 months different toothpastes according to the groups: group A - Sorriso Fresh Red Mint ${ }^{\mathrm{TM}}, 1,100$ ppm F (NaF) - Kolynos do Brasil Ltd; group B - experimental toothpaste with 1,100 ppm $\mathrm{F}(\mathrm{NaF})$ and $0.95 \%$ chlorhexidine digluconate $\left(\mathrm{FGM}^{\mathrm{TM}}\right.$, Joinville) and group C - experimental toothpaste with $0.95 \%$ chlorhexidine digluconate $\left(F G M^{T M}\right.$, Joinville). Clinical examinations were performed at baseline and after 6 and 12 weeks to verify plaque, gingival and bleeding indexes. The enamel extrinsic stainig and the presence of calculus were also observed. The toothpastes with chlorhexidine (with or without fluorine) were statistically more effective than the control toothpaste on the reduction of gingival and bleeding indexes. The maximum benefit was verified for groups $\mathrm{B}$ and $\mathrm{C}$, after six weeks of thootpaste use. This effect was maintained until the end of the study. In relation to the plaque index, all the 3 groups showed statistically significant reductions in examinations of 6 weeks and the results of group B and $C$ were better when compared to group $A$. It was observed a statistically significant increase of staining index, but not an increase of dental calculus. The utilization of sodium fluoride with chlorhexidine did not cause its inativation. The therapeutic use of toothpaste with chlorhexidine (with or without fluorine) might be seen as a simple and efficient administration way of the chemical agent to patients with difficulties to maintain a sactisfatory oral hygiene, as orthodontic patients.
\end{abstract}

